\title{
DEVELOPMENT OF A PATH FORWARD FOR SPECIAL-CASE WASTES AT THE OAK RIDGE RESERVATION
}

OAK RIDGE NATIONAL LABORATORY
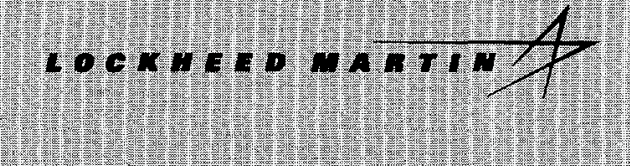

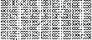
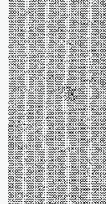$$
\sqrt{\mathrm{H}}
$$

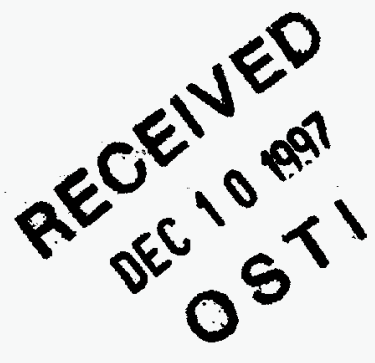

I. W. Osborne-Lee
A. L. Lotts*

R. J. Robinette $\nmid$

*Delta 21 Resources, Inc., Oak Ridge, Tennessee †H\&R Technical Associates, Inc., Oak Ridge, Tennessee

October 1, 1997

Prepared by OAK RIDGE NATIONAL LABORATORY

Oak Ridge, Tennessee 37831 managed by

LOCKHEED MARTIN ENERGY RESEARCH CORP. for the

U.S. DEPARTMENT OF ENERGY under contract DE-AC05-96OR22464 
This report was prepared as an account of work sponsored by an agency of the United States Government. Neither the United States Government nor any agency thereof, nor any of their employees, makes any warranty, express or implied, or assumes any legal liability or responsibility for the accuracy, completeness, or usefuliness of any information, apparatus, product, or process disclosed, or represents that its use would not infringe privately owned rights. Reference herein to any specific commercial product, process, or service by trade name, trademark, manufacturer, or otherwise, does not necessarily constitute or imply its endorsement, recommendation, or favoring by the United States Government or any agency thereof. The views and opinions of authors expressed herein do not necessarily state or reflect those of the United States Government or any agency thereof. 


\section{DISCLAIMER}

Portions of this document may be illegible in electronic image products. Images are produced from the best available original document. 
ORNL/TM-13325

\title{
DEVELOPMENT OF A PATH FORWARD FOR SPECIAL-CASE WASTES AT THE OAK RIDGE RESERVATION
}

\author{
I. W. Osborne-Lee \\ A. L. Lotts* \\ R. J. Robinette $\dagger$
}

*Delta 21 Resources, Inc., Oak Ridge, Tennessee

$\dagger$ †\&R Technical Associates, Inc., Oak Ridge, Tennessee

October 1, 1997

\author{
Prepared by \\ OAK RIDGE NATIONAL LABORATORY \\ Oak Ridge, Tennessee 37831 \\ managed by \\ LOCKHEED MARTIN ENERGY RESEARCH CORP. \\ for the \\ U.S. DEPARTMENT OF ENERGY \\ under contract DE-AC05-96OR22464
}



ACRONYMS AND INITIALISMS $\ldots \ldots \ldots \ldots \ldots \ldots \ldots \ldots \ldots \ldots \ldots$ viii

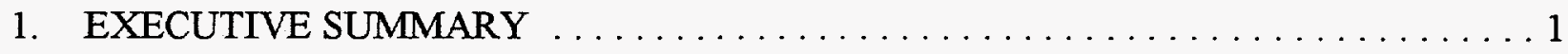

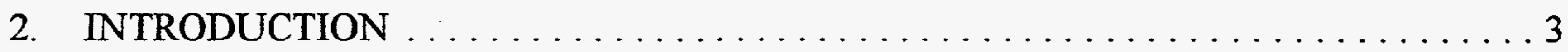

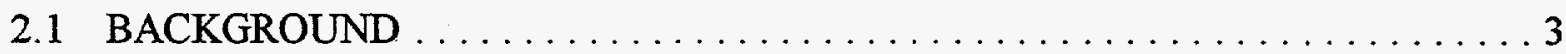

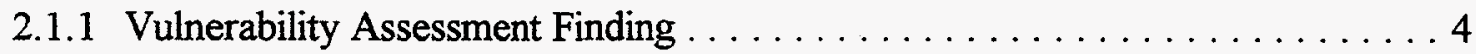

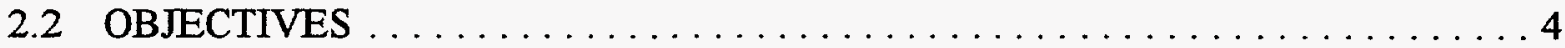

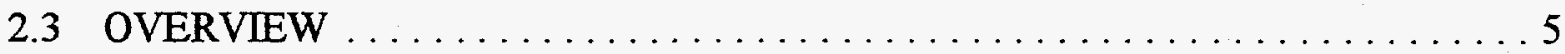

3. DISPOSITION PATH FORWARD ANALYSIS $\ldots \ldots \ldots \ldots \ldots \ldots \ldots \ldots \ldots \ldots$

3.1 OVERALL DISPOSITION OF CEM $\ldots \ldots \ldots \ldots \ldots \ldots \ldots \ldots \ldots \ldots \ldots \ldots$

3.2 REUSE OF MATERIALS $\ldots \ldots \ldots \ldots \ldots \ldots \ldots \ldots \ldots \ldots \ldots \ldots$

3.3 DISPOSITION TO A DEFINED CATEGORY $\ldots \ldots \ldots \ldots \ldots \ldots \ldots \ldots$

3.4 RECYCLE AND FURTHER PROCESSING $\ldots \ldots \ldots \ldots \ldots \ldots \ldots \ldots \ldots$

3.5 COPROCESSING OR SEQUENTIAL PROCESSING $\ldots \ldots \ldots \ldots \ldots \ldots 11$

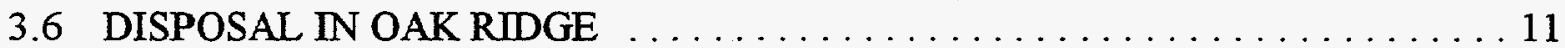

3.7 DISPOSAL AT SITES OUTSIDE OAK RIDGE $\ldots \ldots \ldots \ldots \ldots \ldots \ldots \ldots 11$

3.8 DISPOSITION AT REPOSITORY, MRS, OR OTHER PREPARED SITE $\ldots \ldots 16$

3.9 CEM NOT SUFFICIENTLY CHARACTERIZED $\ldots \ldots \ldots \ldots \ldots \ldots \ldots \ldots$

3.10 STATUS OF DISPOSITION ANALYSIS $\ldots \ldots \ldots \ldots \ldots \ldots \ldots \ldots \ldots \ldots \ldots \ldots$

4. INVENTORY OF MATERIALS REVIEWED . . . . . . . . . . . . . . . . . . . 19

4.1 CATEGORIES OF CEM (POTENTIALLY SCW) . . . . . . . . . . . . 19

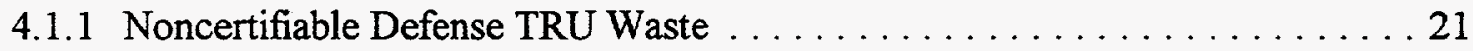

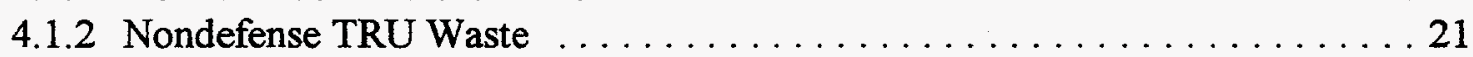

4.1 .3 Greater Than Class C LLW ........................ 21

4.1.4 Performance Assessment Limited Waste $\ldots \ldots \ldots \ldots \ldots \ldots \ldots \ldots \ldots . \ldots \ldots$

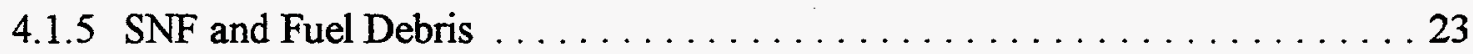

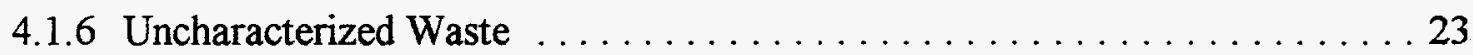

4.1 .7 Excess Nuclear Materials . . . . . . . . . . . . . . . . . . . . . . . . . . 25

4.1 .8 Sealed Radiation Sources . . . . . . . . . . . . . . . . . . . . . . . . 25

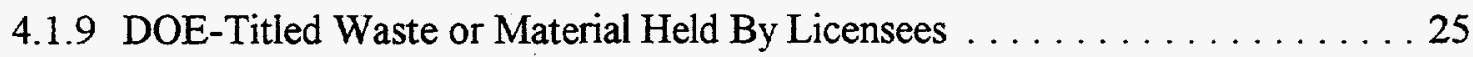

4.2 MATERIALS REVIEWED AT THE ORR $\ldots \ldots \ldots \ldots \ldots \ldots \ldots \ldots \ldots \ldots \ldots \ldots$

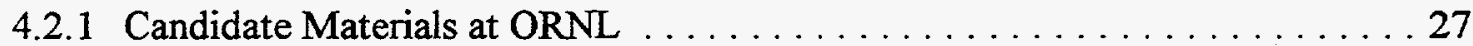

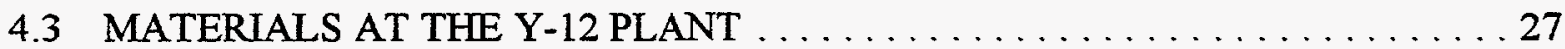

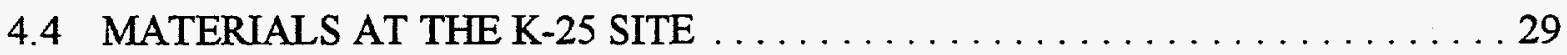

5. PRELIMINARY ANALYSIS OF DISPOSITION OF CANDIDATE EQUIPMENT AND

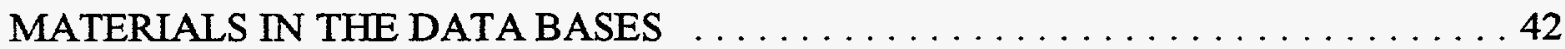

5.1 PATH FORWARD ANALYSIS USING THE OVERALL CHART $\ldots \ldots \ldots \ldots 42$

5.2 DISPOSITION OF CEM BY REUSE AND RECYCLE BY OTHERS $\ldots \ldots \ldots . .44$ 
5.3 DISPOSITION OF CEM BY DEFINED FORM $\ldots \ldots \ldots \ldots \ldots \ldots \ldots \ldots 44$

5.4 DISPOSITION OF CEM TO OFF-SITE FACILITIES $\ldots \ldots \ldots \ldots \ldots \ldots \ldots 47$

5.5 ESTIMATES OF VOLUME, WEIGHT, AND RADIOACTIVITY . . . . . . . . . . 49

6. RECOMMENDATIONS ON A PATH FORWARD FOR SCW ............ 50

6.1 RECOMMENDATIONS FOR MANAGEMENT OF SCW . . . . . . . . . 50

6.1.1 Recommendations Concerning the Means of Disposition of CEM . . . . 50

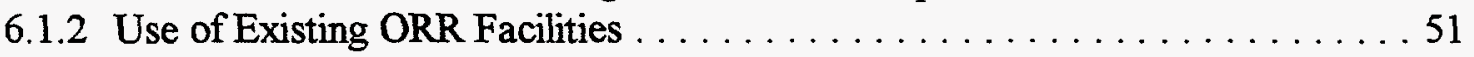

6.1.3 Recommendations for DOE on the Implementation of Policy on Management of SCW .................................. 51

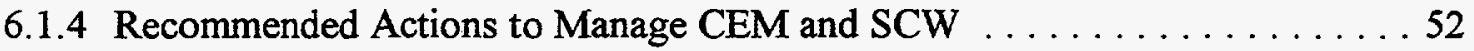

6.1.5 Consequences of Not Implementing Proactive Management of CEM . . . . . 52

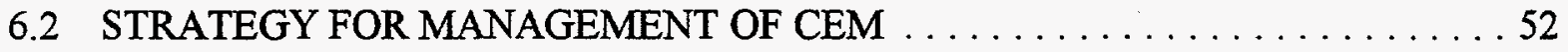

6.2.1 Application of Overall Logic and Decision System . . . . . . . . . . . . 53

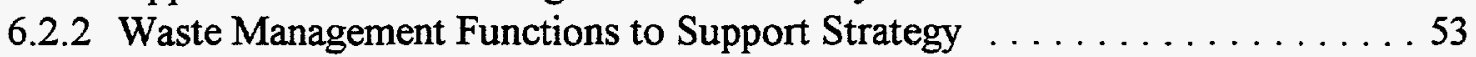

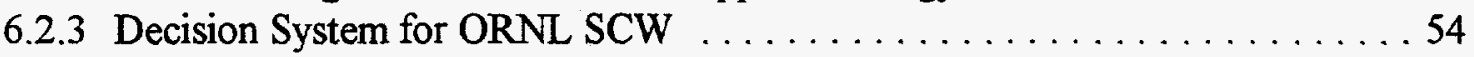

6.3 IMPACT OF STRATEGY ON PRESENT PROGRAM AND PLANS $\ldots \ldots \ldots 54$

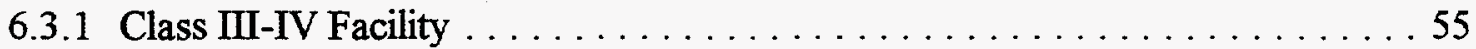

6.3.2 NEPA Impact-Revision of the Environmental Assessment . . . . . . . . 57

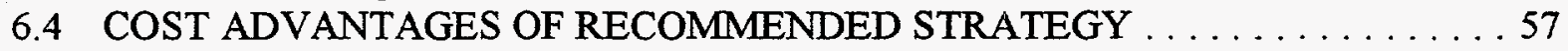

7. SCW ACTIVITIES FOR FISCAL YEAR 1997 AND OUT YEARS . . . . . . . . . 59

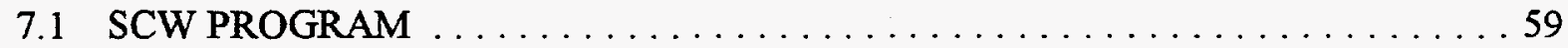

7.1.1 SCW Policy Implementation . . . . . . . . . . . . . . . . . . 59

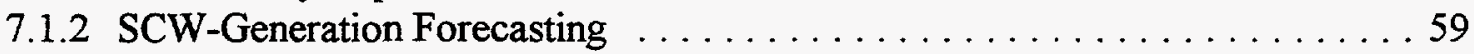

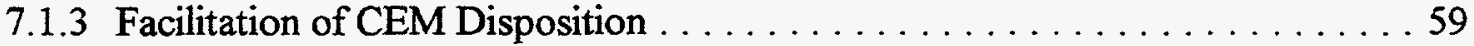

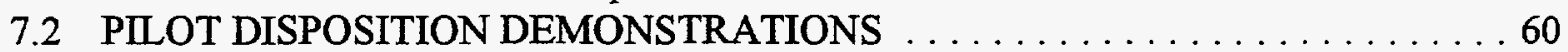

7.3 DEVELOPMENT OF LIFE-CYCLE MODELS BY DISPOSITION PATH . . . 60

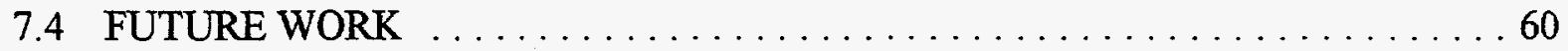

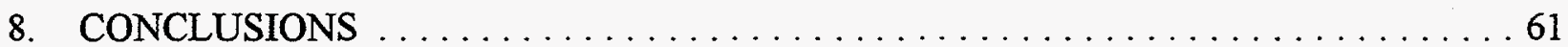

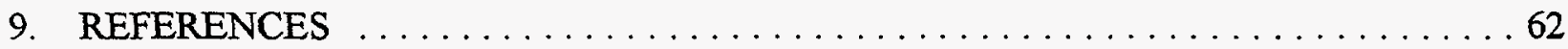

APPENDICES

A. DEFINITION OF VARIOUS MATERIALS IN PROCESS AND WASTE FORMS

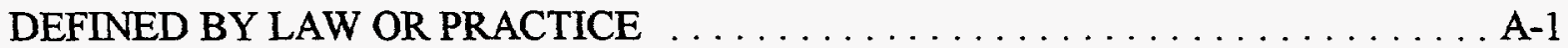

B. WASTE ACCEPTANCE CRITERIA FOR VARIOUS DISPOSAL FACILITIES THROUGHOUT THE DOE COMPLEX ...................

C. GUIDANCE FOR TRANSFER OF EXCESS RADIOACTIVE MATERIALS $\ldots \ldots$. C-1

D. ROUGH ESTIMATE FOR VOLUME OF SPECIAL CASE WASTE AT OAK RIDGE NATIONAL LABORATORY 


\section{LIST OF FIGURES}

Fig. 3.1 Top level logic for the disposition of CEM (Chart 1) .............. 7

Fig. 3.2 Logical process for the disposition of CEM by reuse (Chart 2) ..........

Fig. 3.3 Logical process to determine if CEM meets the criteria for a defined

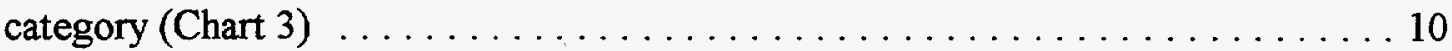

Fig. 3.4 Logical process for the disposition of CEM by recycle or further processing (Chart 4)

Fig. 3.5 Logical process to determine the disposition of CEM by coprocessing or sequential

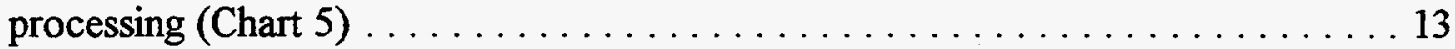

Fig. 3.6 Logical process for the disposition of CEM onsite by PAL acceptance (Chart 6) _. 14

Fig. 3.7 Logical process for the disposition of CEM at off-site facilities (Chart 7) . . . . . 15

Fig. 3.8 Logical process for the disposition of SCW at a repository or MRS (Chart 8) . . 17

Fig. 3.9 Logical process for managing inadequately characterized CEM (Chart 9) . . . . 18

Fig. 4.1 Distribution of various types of LLW generation and storage at the ORR in 1994. . 20

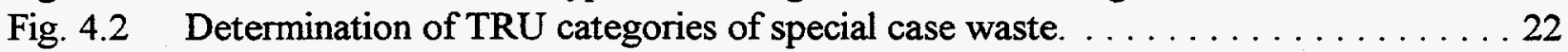

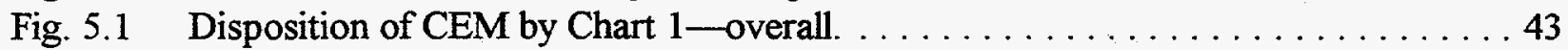

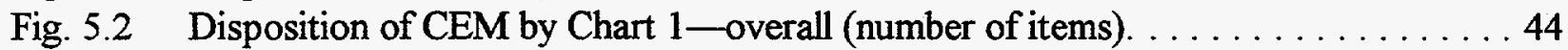

Fig. 5.3 Disposition of CEM by Chart 2-reuse (percentage based on number of items). . . 45

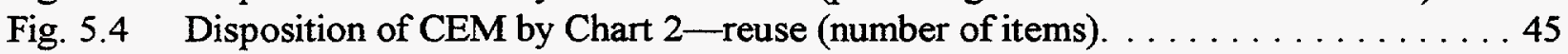

Fig. 5.5 Disposition of CEM by Chart 3-defined form (percentage based on number

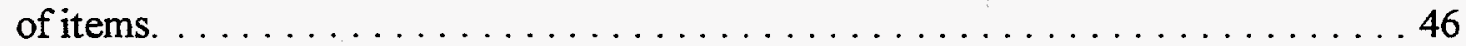

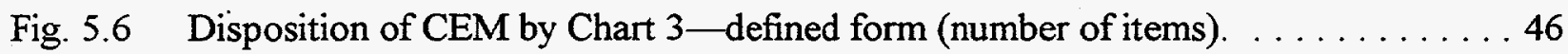

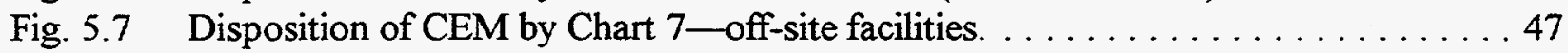

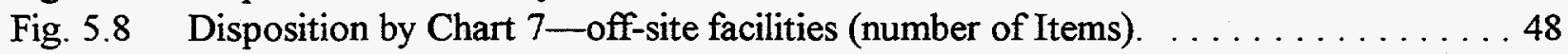

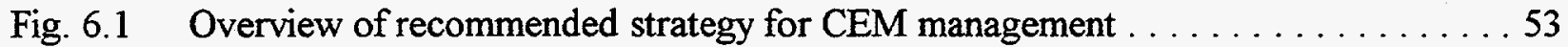

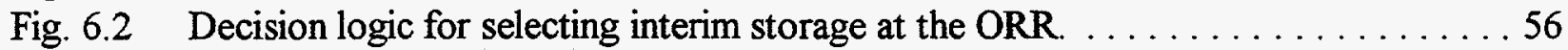

\section{LIST OF TABLES}

Table 2.1 Site-specific vulnerabilities cited for the Oak Ridge Reservation (ORR) $\ldots \ldots \ldots 5$

Table $4.1 \quad$ NRC Limits for Class $\mathrm{C}$ low level radioactive waste . . . . . . . . . . . . 24

Table 4.2 Sealed sources on-loan through the Californium Loan Program ............ 26

Table 4.3 Summary of information on special case waste materials from the ORNL SCW data

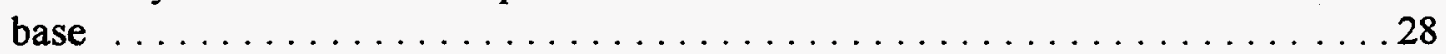

Table 4.4 Scrap metal inventory at ORNL . . . . . . . . . . . . . . . . 29

Table 4.5 Surplus equipment scrap metal inventory at ORNL $\ldots \ldots \ldots \ldots \ldots \ldots \ldots$

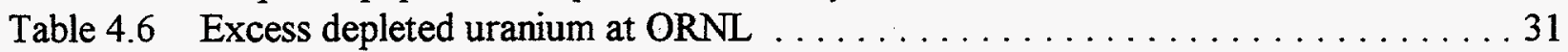

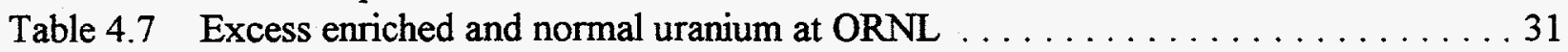

Table 4.8 Lithium hydride $(\mathrm{LiH})$, sodium $(\mathrm{Na})$, potassium $(\mathrm{K})$, and NaK at $\mathrm{ORNL}$ and $\mathrm{ORNL}$

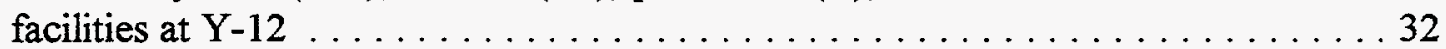

Table 4.9 Excess chemicals and chemicals of special concern at ORNL .......... 33 


\section{LIST OF TABLES (continued)}

Table 4.10 Plutonium and other NMMSS tracked materials at ORNL $\ldots \ldots \ldots \ldots \ldots 33$

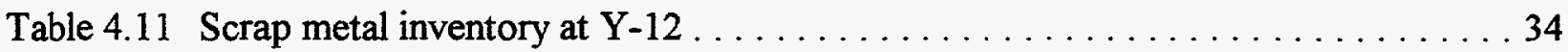

Table 4.12 Excess enriched uranium at the $Y-12$ Plant $\ldots \ldots \ldots \ldots \ldots \ldots \ldots \ldots \ldots$

Table 4.13 Types of bulk lithium material in inventory at the Oak Ridge Reservation . . . . 35

Table 4.14 Excess chemicals and chemicals of special concern at $\mathrm{Y}-12 \ldots \ldots \ldots \ldots . \ldots 36$

Table 4.15 Radioactive source types at the $\mathrm{Y}-12$ Plant $\ldots \ldots \ldots \ldots \ldots \ldots \ldots \ldots \ldots \ldots \ldots \ldots$

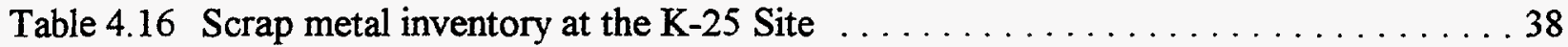

Table 4.17 Process equipment scrap metal inventory at the K-25 Site . . . . . . . . 38

Table 4.18 Inventory of depleted uranium at the K-25 Site and other Oak Ridge Operations

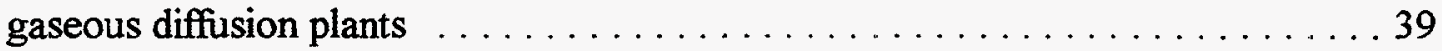

Table 4.19 Description of enriched and natural uranium at the K-25 Site . . . . . . . . . . 39

Table 4.20 Current storage locations and inventory for bulk lithium at $\mathrm{K}-25 \ldots \ldots \ldots \ldots 40$

Table 4.21 Excess chemicals and chemical of special concern at the K-25 Site . . . . . . 41

Table 4.22 Plutonium inventory at the K-25 Site $\ldots \ldots \ldots \ldots \ldots \ldots \ldots \ldots \ldots \ldots \ldots \ldots$ 


\section{ACRONYMS AND INITIALISMS}

$\begin{array}{ll}\text { AEA } & \text { Atomic Energy Act } \\ \text { ALARA } & \text { as low as reasonably achievable } \\ \text { BSR } & \text { Bulk Shielding Reactor } \\ \text { CEM } & \text { candidate equipment and/or material(s) } \\ \text { CH-TRU } & \text { contact-handled transuranic } \\ \text { D\&D } & \text { decontamination and decommissioning } \\ \text { DOE } & \text { U. S. Department of Energy } \\ \text { DOE-NE } & \text { U. S. Department of Energy, Office of Nuclear Energy } \\ \text { DOE-EM } & \text { U. S. Department of Energy, Office of Environmental Management } \\ \text { DOT } & \text { U. S. Department of Transportation } \\ \text { DU } & \text { depleted uranium } \\ \text { ENM } & \text { excess nuclear material(s) } \\ \text { FGE } & \text { fissile gram equivalent(s) } \\ \text { FY } & \text { fiscal year } \\ \text { FONSI } & \text { findings of no significant impact } \\ \text { GDP } & \text { gaseous diffusion plant } \\ \text { GPP } & \text { general plant project } \\ \text { GTCC } & \text { Greater than Class C } \\ \text { GVW } & \text { gross vehicle weight } \\ \text { HCWF } & \text { Hanford Central Waste Facility } \\ \text { HEU } & \text { highly enriched uranium } \\ \text { HFIR } & \text { High Flux Isotope Reactor } \\ \text { HLW } & \text { high-level waste } \\ \text { HRE } & \text { Homogeneous Reactor Experiment } \\ \text { IAEA } & \text { International Atomic Energy Agency } \\ \text { INEEL } & \text { Idaho National Engineering and Environmental Laboratory } \\ \text { IWMF } & \text { Interim Waste Management Facility } \\ \text { LANL } & \text { Los Alamos National Laboratory } \\ \text { LEU } & \text { low enriched uranium } \\ \text { LMER } & \text { Lockheed Martin Energy Research Corp. } \\ \text { LMES } & \text { Lockheed Martin Energy Systems, Inc. } \\ \text { LLW } & \text { low-level waste } \\ \text { MBA } & \text { material balance area } \\ \text { M\&C } & \text { Metals and Ceramics Division } \\ \text { MIN } & \text { Material in Inventory } \\ \text { MRS } & \text { monitored retrievable storage } \\ \text { MSR } & \text { Molten Salt Reactor } \\ \text { MSRE } & \text { Molten Salt Reactor Experiment } \\ & \end{array}$


NDA

NDE

NEPA

NFS

NMD

NMMSS

NRC

NTS

OORFS

ORNL

ORR

PAL

QA

QAPjP

QC

R\&D

RCRA

REDC

SARP

SCW

SNF

SNL

SNM

SRS

SRWF

SWB

SWSA

TRU

TSF

VOC

WAC

WESF

WIPP

WMO

WMRAD nondestructive assay

nondestructive examination

National Environmental Protection Act

Nuclear Fuel Services, Inc.

no-migration determination

Nuclear Materials Management Safeguards System

U.S. Nuclear Regulatory Commission

Nevada Test Site

Office of Operational Readiness and Facility Safety

Oak Ridge National Laboratory

Oak Ridge Reservation

Performance Assessment Limit

quality assurance

Quality Assurance Project Plan

quality control

research and development

Resource Conservation and Recovery Act

Radiochemical Engineering Development Center

Safety Analysis Report for Packaging

special case waste

spent nuclear fuel

Sandia National Laboratory

special nuclear material(s)

Savannah River Site

Savannah River Waste Facility

standard waste box(es)

solid waste storage area

transuranic

Tower Shielding Facility

volatile organic compound

waste acceptance criteria

Waste Encapsulation and Storage Facility

Waste Isolation Pilot Plant

waste management organization

Waste Management and Remedial Action Division 


\section{EXECUTIVE SUMMARY}

This report addresses the management of the inventory of existing and potential surplus equipment and materials at the Oak Ridge Reservation (ORR) that are candidates for various waste or surplus material categories, including special case waste (SCW). This inventory is called candidate equipment and materials (CEM). This report presents a logical method for disposition of this and future CEM, summarizes the inventory, and suggests preliminary dispositions for the CEM. Also, recommendations are offered for an improved CEM management strategy and actions in this and future years to implement that strategy.

SCW is waste for which there is no planned disposition. Invariably, material becomes SCW because its disposition is problematic due to technical difficulties, ALARA* considerations, contemporary program scope limitations, or other challenges.

In the study reported herein, the task of developing paths forward for CEM at the ORR was undertaken. This work builds upon earlier studies which were reported by the Waste Management and Remedial Action Division (WMRAD) in 1995. The earlier studies focused on Oak Ridge National Laboratory (ORNL) SCW (or CEM, as it is called in this study). However, this study expands to include CEM from the Y-12 Plant and the K-25 Site (now the East Tennessee Technology Park). The resultant inventory data base provided an adequate basis for this study. However, the need for better inventory data to support an effective SCW management program, including SCW disposition campaigns, is recognized.

The approach to developing paths forward was threefold: identification of materials that are CEM, examination of CEM on a case-by-case basis to determine disposition options, and consideration of alternative paths forward for CEM remaining and identified as SCW. In the analysis, the inventory of equipment and materials in terms of the requirements for its management and final disposition was considered. The overall objective in the disposition analysis is to obtain the best alternative in terms of a balance of reuse, recycle, or disposal.

There are nearly 3,000 items in the data base representing CEM from ORNL, Y-12, and K-25. About $66 \%$ of these items are sources, about $12 \%$ of the items can probably be reused, about $25 \%$ meet the definition of materials or wastes that are the responsibility of in-progress funded programs, and about $35 \%$ of the CEM are under the performance assessment limits (PALs) for near-surface disposal at the ORR. Disposition at other sites, primarily at the Nevada Test Site (NTS), the Hanford Central Waste Facility (HCWF), and the Waste Encapsulation and Storage Facility (WESF), accounts for $21 \%$. About $7 \%$ of the items are not characterized sufficiently for a determination of the disposition method to be made at this stage. Hence, it is not possible at this stage of the analysis to be precise about the amount of CEM that will become SCW. Further disposition-path analysis and more data are required. The amount of SCW based on the number of items inventoried will likely be significant, probably ranging from 5 to $20 \%$.

"ALARA refers to the practice, enforced by law, of keeping worker exposure to radiation "as low as reasonably achievable" (ALARA). 
It is important to note that the disposition paths resulting from this analysis are proffered as an approximation of what might be possible; they represent a starting point for a more detailed consideration of the path forward to resolution of management issues related to each of the CEM items.

As a result of this study, implementation of a proactive management strategy is recommended for dealing with the CEM that could become SCW. This strategy would implement the logical method and decisionanalysis tools presented in this report. The strategy would require that waste management operations and generators and holders of CEM dispose of the CEM by the best available means. One important implication of the recommended strategy is that the Class III-IV Storage Facility would no longer be required. Disposition options for CEM would be determined using the logical process, at which point the CEM would be packaged and stored for final disposition. The waste management organization would provide assistance to CEM holders in identifying options and in properly packaging the items, and then would accept the packaged CEM to complete its disposition, using existing waste management storage capacity for contingencies. A preliminary assessment indicates that the recommended strategy will lead to significant cost savings, starting with the $\$ 2$ million for the basic Class III-IV facility. 


\section{INTRODUCTION}

In this report, an issue identified by the U.S. Department of Energy (DOE), Office of Environmental Management ${ }^{1}$ (DOE-EM) is addressed concerning the low-level radioactive waste (LLW) for which there is no identified or a technical path forward for disposition. Most of the materials and equipment that do not have an identified or a technical path forward have been inventoried and now need disposition paths that will result in appropriate long-term management strategies.

This study addresses the management of the inventory of existing and potentially surplus equipment and materials at ORR that are candidates for various waste or surplus material categories, including SCW. This inventory is called CEM. This report describes a logical method for the disposition of this inventory and future CEMs, summarizes the inventory based on available information, and presents a preliminary disposition of the CEM. Finally, this report gives a recommended course of action leading to an improved path-forward strategy for SCW.

\subsection{BACKGROUND}

The inventory of surplus equipment and materials includes a wide range of materials and isotopes. Some of the CEMs are still in use, but may become surplus. Some have been identified by managers of particular categories of waste or surplus material and are already being managed for appropriate disposition by their programs. For example, most of the spent nuclear fuel (SNF) has been identified as being managed by the SNF Program. In the past, much of the CEM has not been assigned to appropriate programs for management or has been designated SCW if it is not assignable.

SCW is material which has been declared as waste and for which there is no planned disposition. Invariably, material becomes SCW because its disposition is problematic due to technical difficulties, ALARA considerations, contemporary program scope limitations, or other challenges.

The ORR encompasses three sites: ORNL, the Y-12 Plant, and the K-25 Environmental Restoration Site. Historically, the ORR has produced diverse waste streams. Additionally, each site has on hand a variety of materials that are either in active use or being held for future use. These materials in inventory are not currently wastes, but some of these materials have the potential to become SCW. ORNL CEM have typically been generated from research projects such as the Molten Salt Reactor (MSR) and the High Flux Isotope Reactor (HFIR) and from environmental restoration activities.

The existence of the CEM that have not been assigned to appropriate programs and that are potentially SCW represents a concern, because this material must be continually managed to protect human health and the environment. Thus, the development of a path forward for each component of the CEM provides an opportunity to reduce both risk and cost associated with the ongoing management of the associated materials. 


\subsubsection{Vulnerability Assessment Finding}

In May 1996, DOE-EM issued a final report ${ }^{1}$ on environmental safety and health-related vulnerabilities at its facilities nationwide. Among the 45 site-specific vulnerabilities identified across the DOE complex, the following 6 were recognized as being complex-wide:

- Inadequate LLW forecasting and capacity planning

- Ineffective characterization of LLW

- Continued storage of LLW that has a path forward for disposal

- Inadequate storage conditions for LLW

- LLW for which there is no identified technical path forward for disposition

- Performance assessments not approved and lacking adequate requirements

This report addresses the fifth vulnerability-development of a plan for the disposition of certain LLW for which there is no currently identified technical path forward for disposition. This vulnerability was also one of eight findings for the ORR (Table 2.1).

The existence of SCW is considered a vulnerability, although much of the material is relatively secure in locations such as hot cells. Potential concerns cited include: (1) the risk of a fire or explosion, with subsequent spreading of highly radioactive material and dust to the environment and to adjacent public roads, and (2) the risk of inadvertent worker exposure to radiation that could occur if administrative controls or engineered barriers became inadequate. The risk associated with SCW without a path forward was described as medium, which was the highest impact level cited for the ORR.

\subsection{OBJECTIVES}

In this study, the task was undertaken to develop paths forward for CEM on the ORR. This study builds upon earlier studies: the first, a survey and study by Idaho National Engineering and Environmental Laboratory (INEEL) personnel in $1990,{ }^{2}$ and the second, an update which was reported by WMRAD personnel in $1995 .{ }^{3}$ These previous studies focused on ORNL SCW. In this study, the focus is on material with the potential to become SCW, which is referred to as CEM. In addition, this study expands upon the scope of the previous two studies to include CEM from the Y-12 Plant and the K-25 Site as well as from ORNL.

The approach to developing paths forward is threefold: (1) identification of materials that are CEM, (2) examination of CEM on a case-by-case basis to determine disposition options if they exist, and (3) consideration of alternative paths forward for CEM remaining and identified as SCW. The intent is to classify the CEM by using a set of disposition alternatives to identify plausible paths. 
Table 2.1. Site-specific vulnerabilities cited for the ORR

\begin{tabular}{lc}
\hline Vulnerability cited & Impact/risk level \\
\hline SCW with no path forward & Medium \\
Process tracking and trending at ORR & Medium \\
Storage of LLW for which a path forward has been identified & Low \\
$\begin{array}{l}\text { Uncharacterized legacy waste managed at ORR } \\
\text { Disposal curie inventory at the X-10 Interim Waste Management Facilities } \\
\quad \text { (IWMF) (Building 7886) }\end{array}$ & Low \\
$\begin{array}{l}\text { Performance assessment indicators for solid waste storage area (SWSA) } \\
\quad \text { No. 6 Facilities }\end{array}$ & Medium \\
$\begin{array}{l}\text { Emergency planning for natural phenomena impacting ORR LLW } \\
\text { management facilities }\end{array}$ & Medium \\
Waste storage pads continuing release & Medium \\
\hline
\end{tabular}

\subsection{OVERVIEW}

In this report, path-forward alternatives for CEM at the ORR. are examined. The generation of pathforward alternatives requires a consideration of potential disposition options and a methodology for evaluating and assigning disposition options to CEM on a case-by-case basis. Disposition options and the analysis logic are presented in Sect. 3. Materials at the three sites that could become SCW are discussed in Sect. 4. A preliminary inventory of CEM is identified for use in illustrating the application of the pathforward logic. Of ultimate interest is the disposition of CEM and the forecast of SCW, which are discussed in Sect. 5. A recommendation for a new SCW path forward strategy with the potential for cost savings is given in Sect. 6. Future activities are discussed in Sect. 7. Finally, the conclusions from this report are summarized in Sect. 8. 


\section{DISPOSITION PATH-FORWARD ANALYSIS}

In this analysis, the inventory of equipment and materials has been considered in terms of the requirements for managing and finally disposing of the CEM inventory. The disposition paths are given via a series of nine logic diagrams presented in this section. The overall objective in the disposition analysis is to obtain the best alternative in terms of a balance of reuse, recycle, or disposal. Thus, it may become necessary to request special consideration of programs to recycle materials or to request waivers for some of the requirements of disposal facilities. For example, it is logical to recycle ${ }^{252} \mathrm{Cf}$ sources after they have decayed because new sources can be made from the decayed isotopes, primarily ${ }^{248} \mathrm{Cm}$. Nothing in this philosophy or approach is intended to compromise safety or the requirements for long-term stability and adequate performance.

\subsection{OVERALL DISPOSITION OF CEM (CHART 1)}

The first chart (Fig. 3.1) gives the overall strategy for disposition of the materials. The other eight charts are used to show the disposition of the CEM into a detailed management path. The disposition cascades through a decision process which helps to determine answers to the following:

1. Is the CEM adequately characterized?

2. Is the CEM suitable for reuse?

3. Does the respective CEM meet the criteria for a particular material or waste that is managed by an existing program?

4. Is the CEM suitable for recycling or processing for volume reduction?

5. Is the CEM suitable for coprocessing with other wastes or for subsequent processing in the same facility?

6. Does the CEM meet the performance assessment limits of an Oak Ridge Reservation waste disposal site?

7. Does the CEM meet the performance assessment limits for disposal or storage at a site outside Oak Ridge?

Any CEM not meeting any of the above requirements is defined as SCW, and adequate facilities must be prepared for it in Oak Ridge or elsewhere to achieve its disposition. 


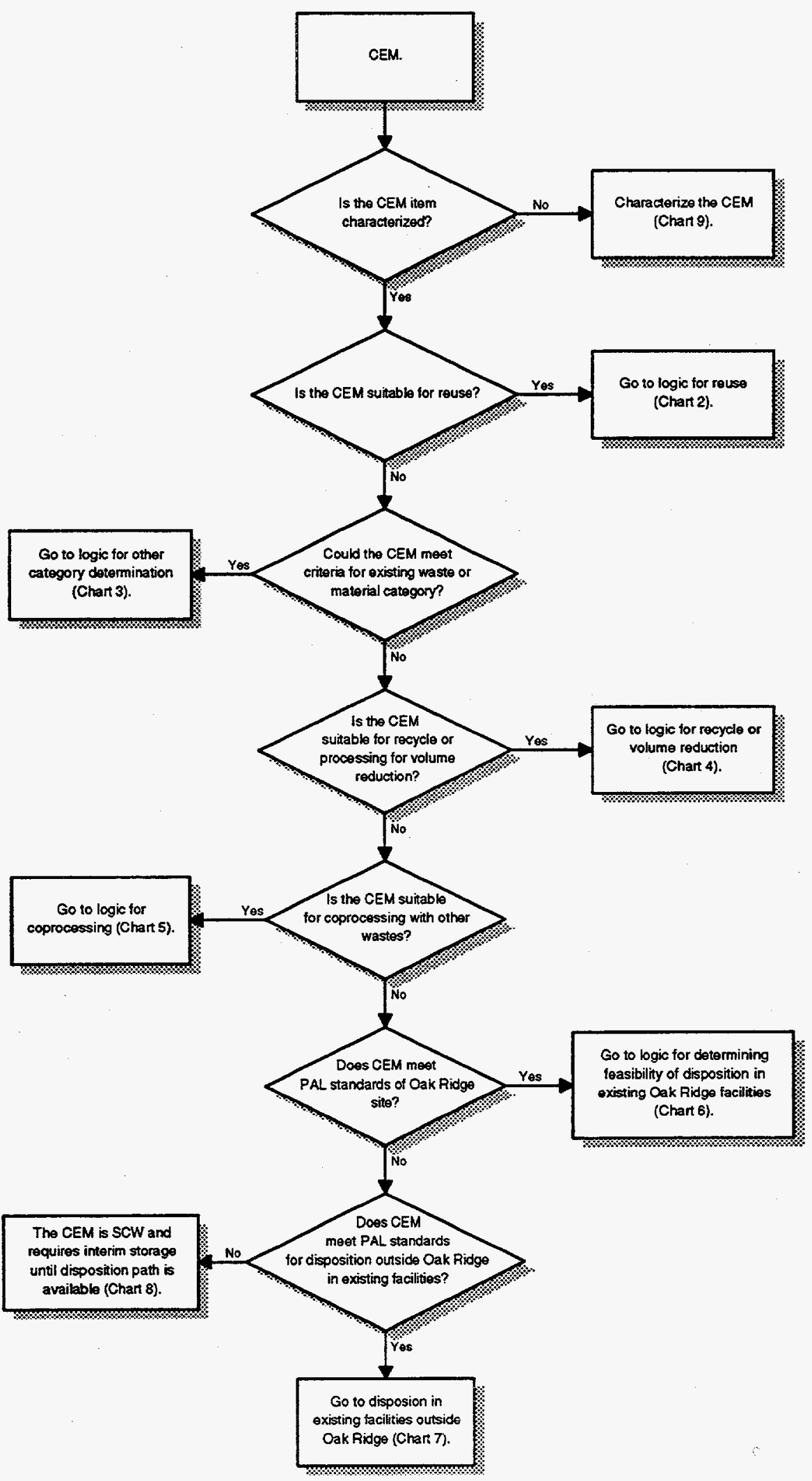

Fig. 3.1. Top-level logic for the disposition of CEM (Chart 1). 


\subsection{REUSE OF MATERIALS (CHART 2)}

Disposition of CEM for reuse is given in Chart 2 (Fig. 3.2). In some cases, there are existing governmental programs that can accept the equipment or materials for reuse. For example, Los Alamos National Laboratory (LANL) will take sources for reuse such as plutonium-beryllium. Some of the materials can be disposed of commercially. For example, excess chemicals and materials that are not contaminated with hazardous or radioactive materials can be sold on the commercial market. In other cases, there may be a reasonable possibility of developing a commercial market for some of the materials. For example, some of the sealed sources may be of sufficient interest such as to be transferred to a nongovernment user.

\subsection{DISPOSITION TO A DEFINED CATEGORY (CHART 3)}

Disposition of CEM by virtue of its ability to meet the criteria for definition of a material in process or a waste form defined by law or practice is outlined in Chart 3 (Fig. 3.3). The definitions considered are as follows:

1. Depleted uranium (DU).

2. Special nuclear materials (SNM)-enriched and natural uranium.

3. Plutonium $/{ }^{233} \mathrm{U}$ program for all isotopes of plutonium and ${ }^{232} U$ and ${ }^{233} U$.

4. SNF, including fuel specimens and combined fission products.

5. Transuranic (TRU) waste, defined as greater than $100 \mathrm{nCi}$. The program will pursue the disposition of all TRU waste at the Waste Isolation Pilot Plant (WIPP).

6. Mixed waste, defined as containing hazardous materials and radioactive isotopes normally disposed of as LLW.

7. Resource Conservation and Recovery Act (RCRA) waste containing listed materials.

8. LLW at the ORR, defined as limited to isotopic concentrations not exceeding acceptable limits.

9. Greater than Class C (GTCC)-waste containing isotopes in concentrations exceeding definition of Class C by the U.S. Nuclear Regulatory Commission (NRC).

The definitions of these wastes are given in Appendix A. 


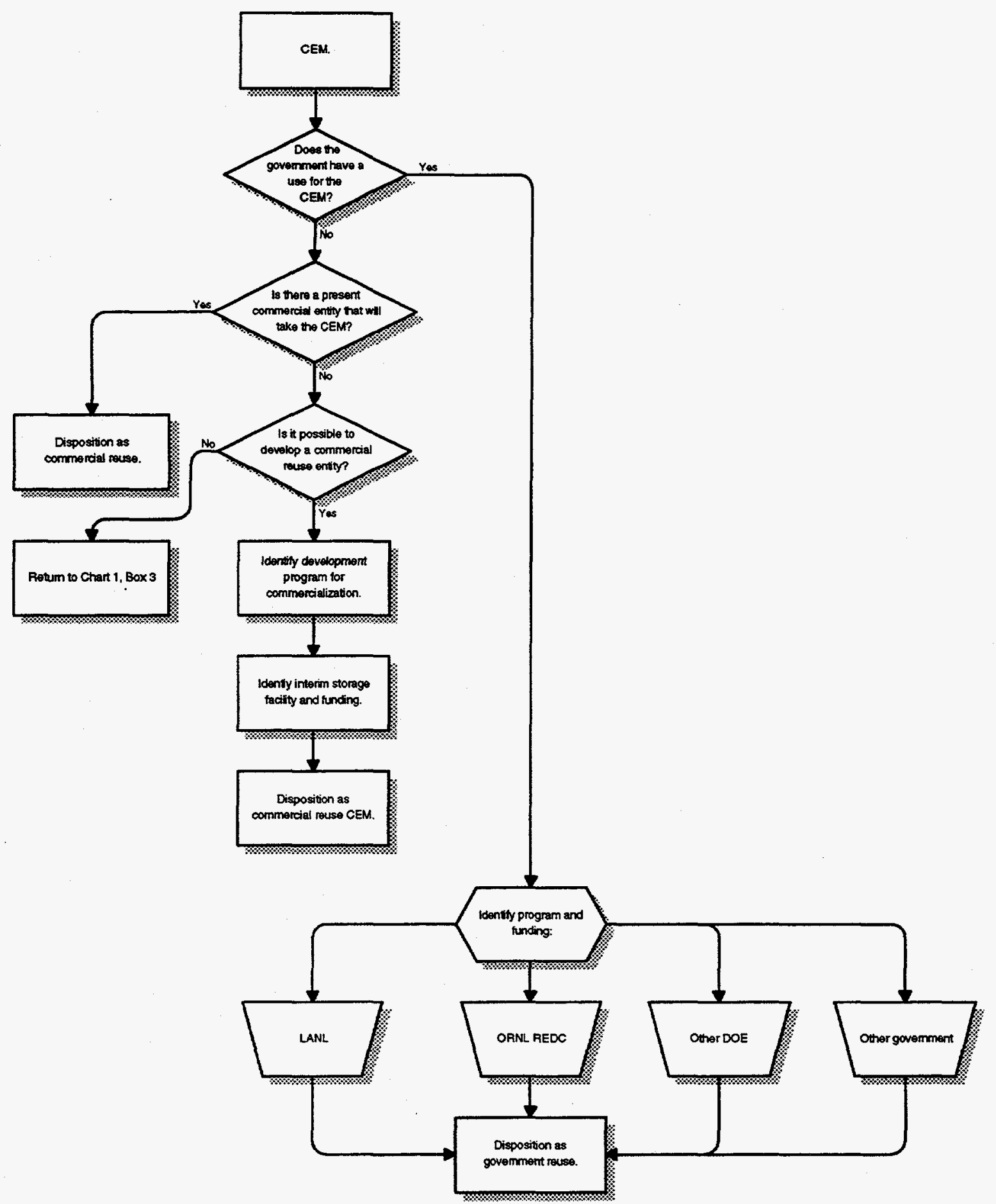

Fig. 3.2. Logical process for the disposition of CEM for reuse (Chart 2). 


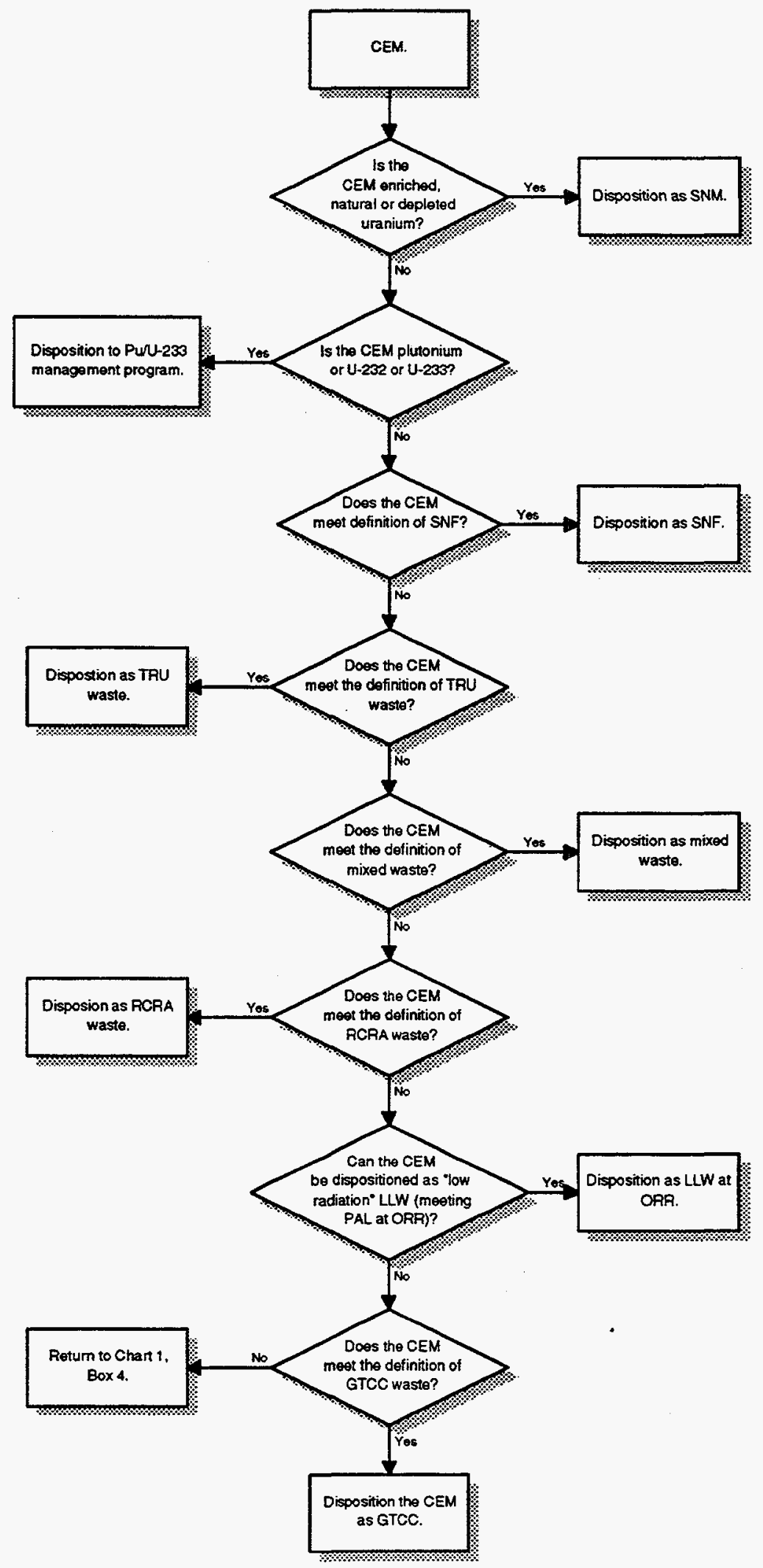

Fig. 3.3. Logical process to determine if CEM meets the criteria for a defined category (Chart 3). 


\subsection{RECYCLE AND FURTHER PROCESSING (CHART 4)}

The disposition of CEM by recycle and further processing is given in Chart 4 (Fig. 3.4). This chart gives alternatives for reducing the amount or volume of the waste by segregating high radiation or hazardous material from the bulk of the material. This segregation can be done mechanically or chemically. In some cases, the materials can be dispositioned by recycle for further use.

\subsection{COPROCESSING OR SEQUENTIAL PROCESSING (CHART 5)}

The disposition of CEM by processing with or processing before or after the processing of other materials is covered by Chart 5 (Fig. 3.5). The main alternative considered was processing with or following TRU waste processing. For example, the planned processing on the Oak Ridge site of TRU waste affords an opportunity to process some of the materials before or following the processing of supernate, sludge, or solid wastes, especially remote handled wastes.

\subsection{DISPOSAL IN OAK RIDGE (CHART 6)}

The disposition of CEM which will meet the requirement of the new IWMF in Oak Ridge is outlined in Chart 6 (Fig. 3.6). The chart shows no other disposition possibilities in Oak Ridge. The waste acceptance criteria (WAC) for the IWMF are given in Appendix B.

\subsection{DISPOSAL AT SITES OUTSIDE OAK RIDGE (CHART 7)}

The disposition of CEM in facilities outside of Oak Ridge is shown in Chart 7 (Fig. 3.7). The facilities considered in this study are:

- NTS

- WIPP

- WESF

- HCWF

- Savannah River Waste Facility (SRWF)

- Envirocare

- Barnwell

The criteria for acceptance of wastes for some of these sites are given in Appendix B. 


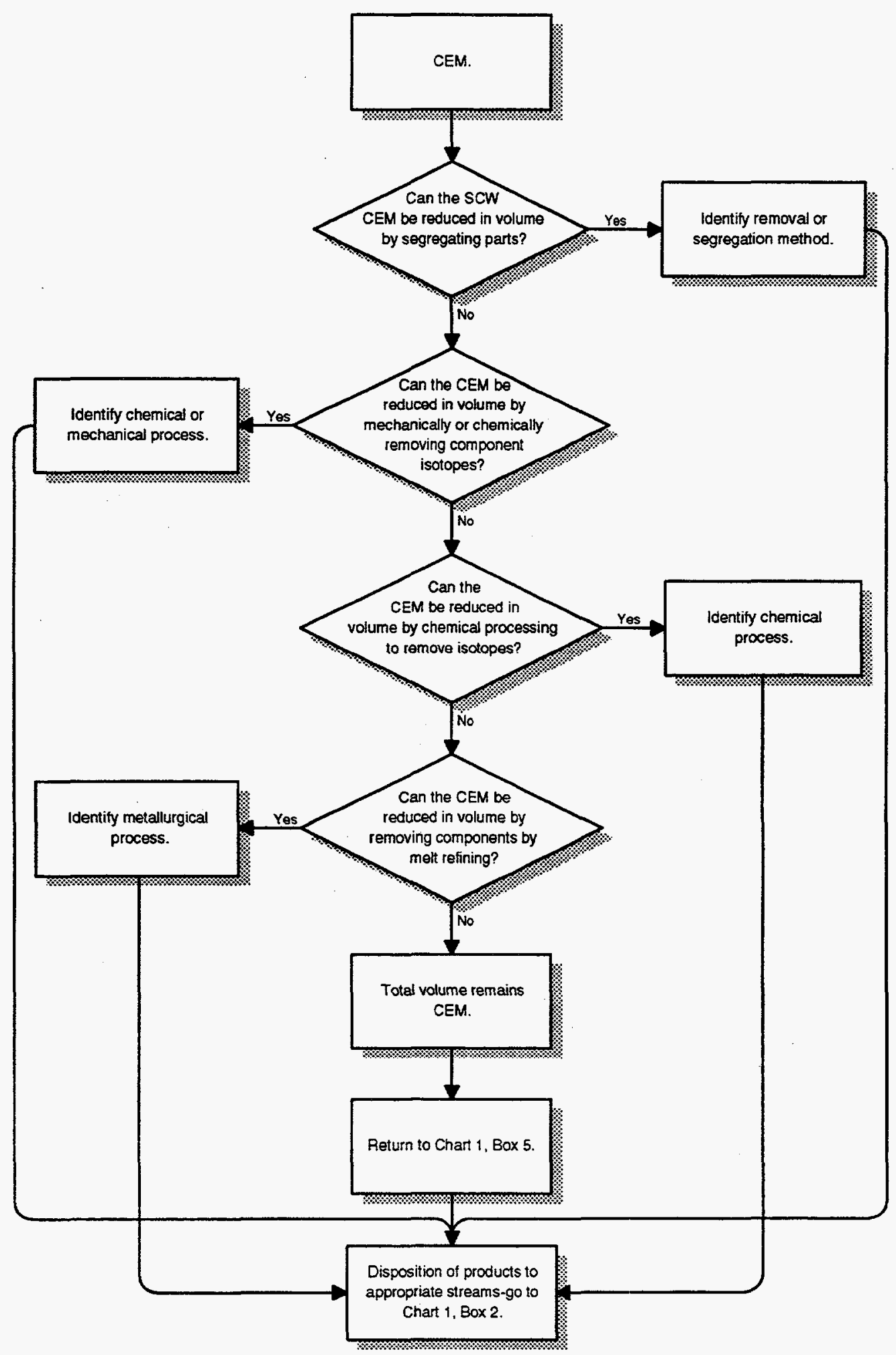

Fig. 3.4. Logical process for the disposition of CEM by recycle or further processing (Chart 4). 


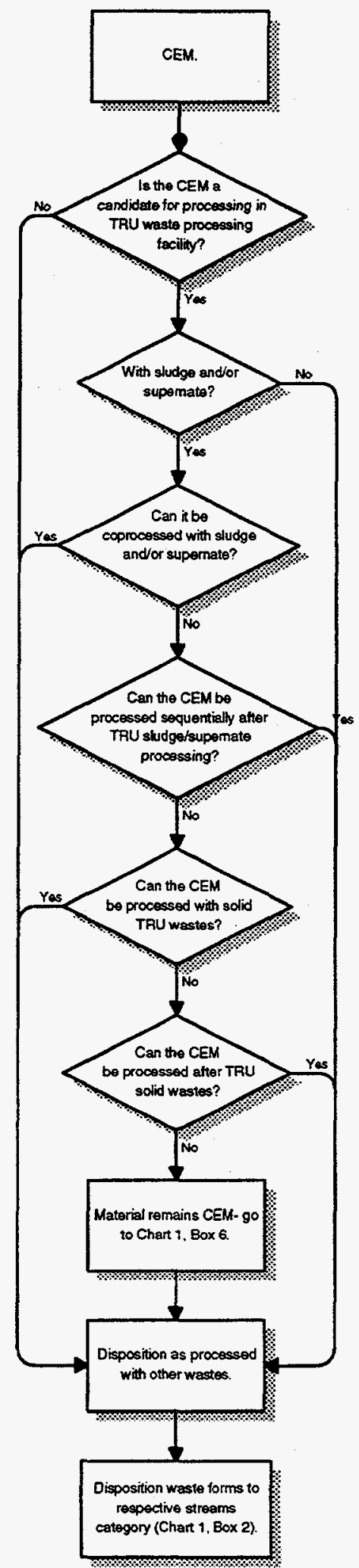

Fig. 3.5. Logical process to determine the disposition of CEM by coprocessing or sequential processing (Chart 5). 


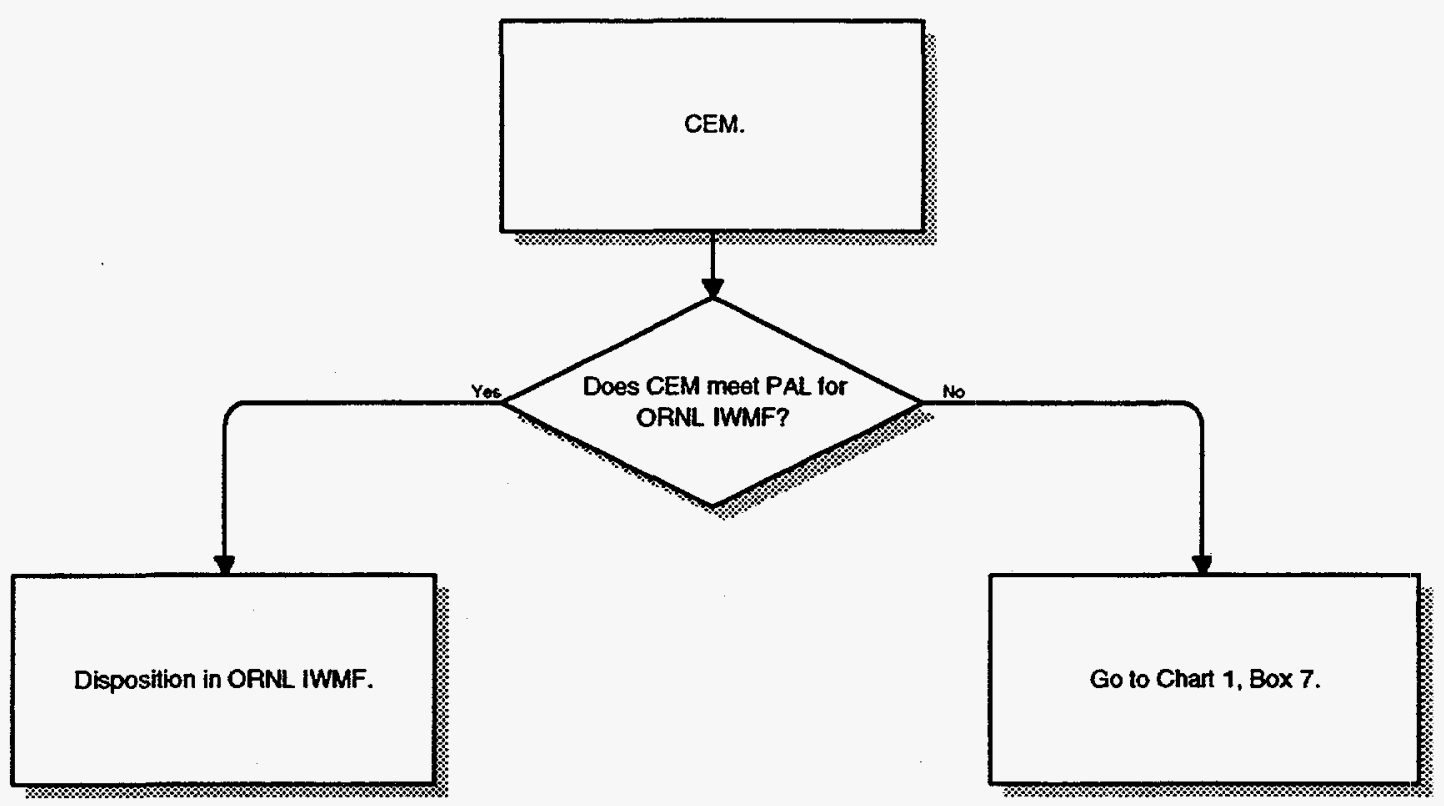

Fig. 3.6. Logical process for the disposition of CEM on-site by meeting PALs (Chart 6). 


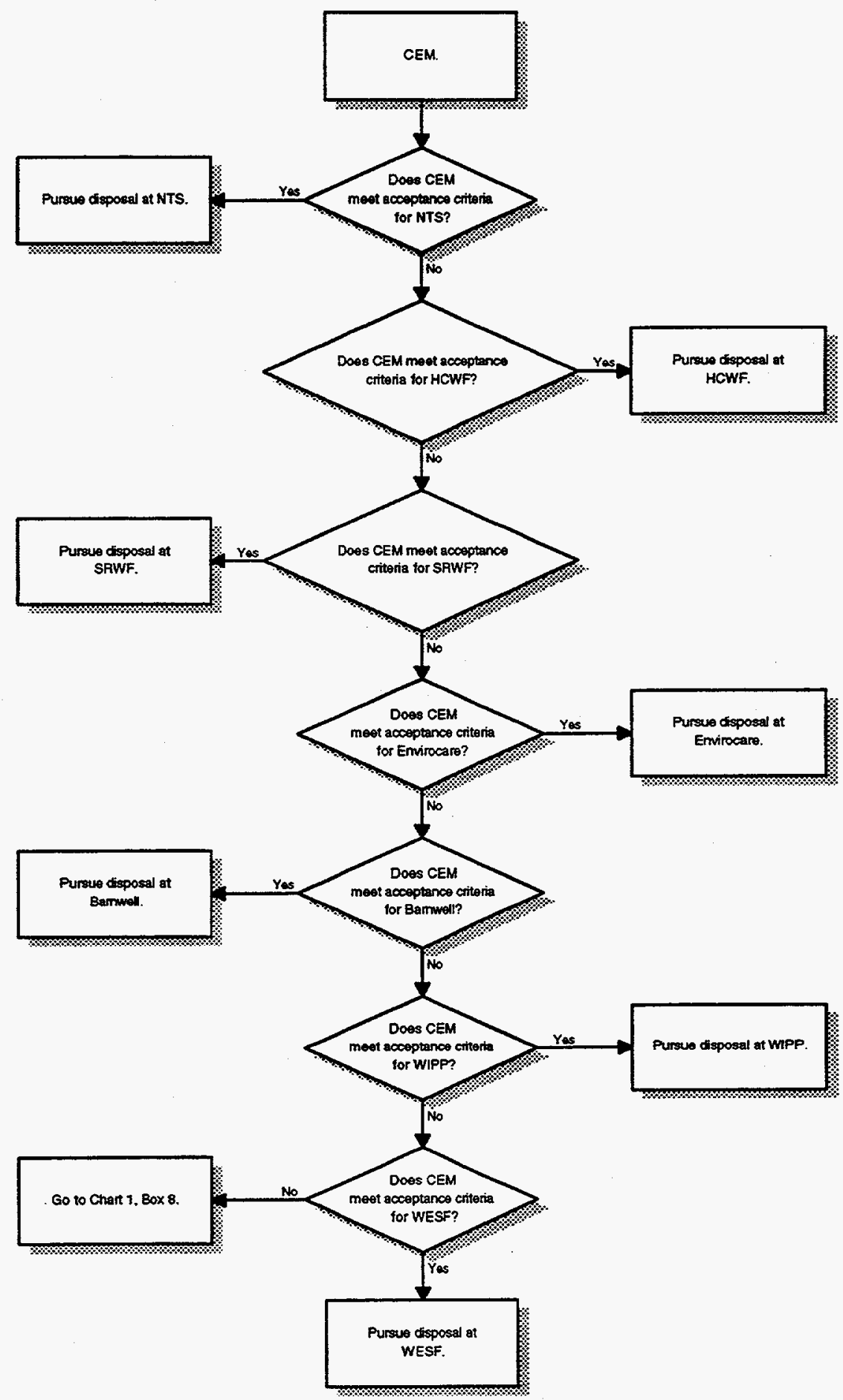

Fig. 3.7. Logical process for disposition of CEM at off-site facilities (Chart 7). 


\subsection{DISPOSITION AT REPOSITORY, MRS, OR OTHER PREPARED SITE (CHAIRT 8)}

Any CEM that cannot be dispositioned by the steps outlined in Charts 3 through 7 (Figs. 3.3-3.7) will be identified as SCW and must be dispositioned in a repository, monitored retrievable storage (MRS) facility, or another special facility prepared for waste storage in Oak Ridge. This disposition is outlined in Chart 8 (Fig. 3.8).

\subsection{CEM NOT SUFFICIENTLY CHARACTERIZED (CHART 9)}

Some of the CEM may not be sufficiently characterized such as to enable disposition according to the previous charts. Such wastes must be characterized after first seeking additional historical information or performing analytical work on the CEM. This is depicted by Chart 9 (Fig. 3.9).

\subsection{STATUS OF DISPOSITION ANALYSIS}

The methodology presented in Charts 1-9 (Figs. 3.1-3.9) provides a road map for path-forward analysis for CEM. Following the establishment of this approach, material at the ORR began to undergo assessment to determine the extent of existing and future SCW. At the time of this report, an initial pass at the top-level analysis, as embodied in Chart 1 (Fig. 3.1), was completed. In the process of applying Chart 1, dispositions embodied in Charts 3 and 7 (Figs. 3.3 and 3.7) also were evaluated. Therefore, to date, three of the nine charts have been exercised. Results of the analysis are presented in Sect. 5. 


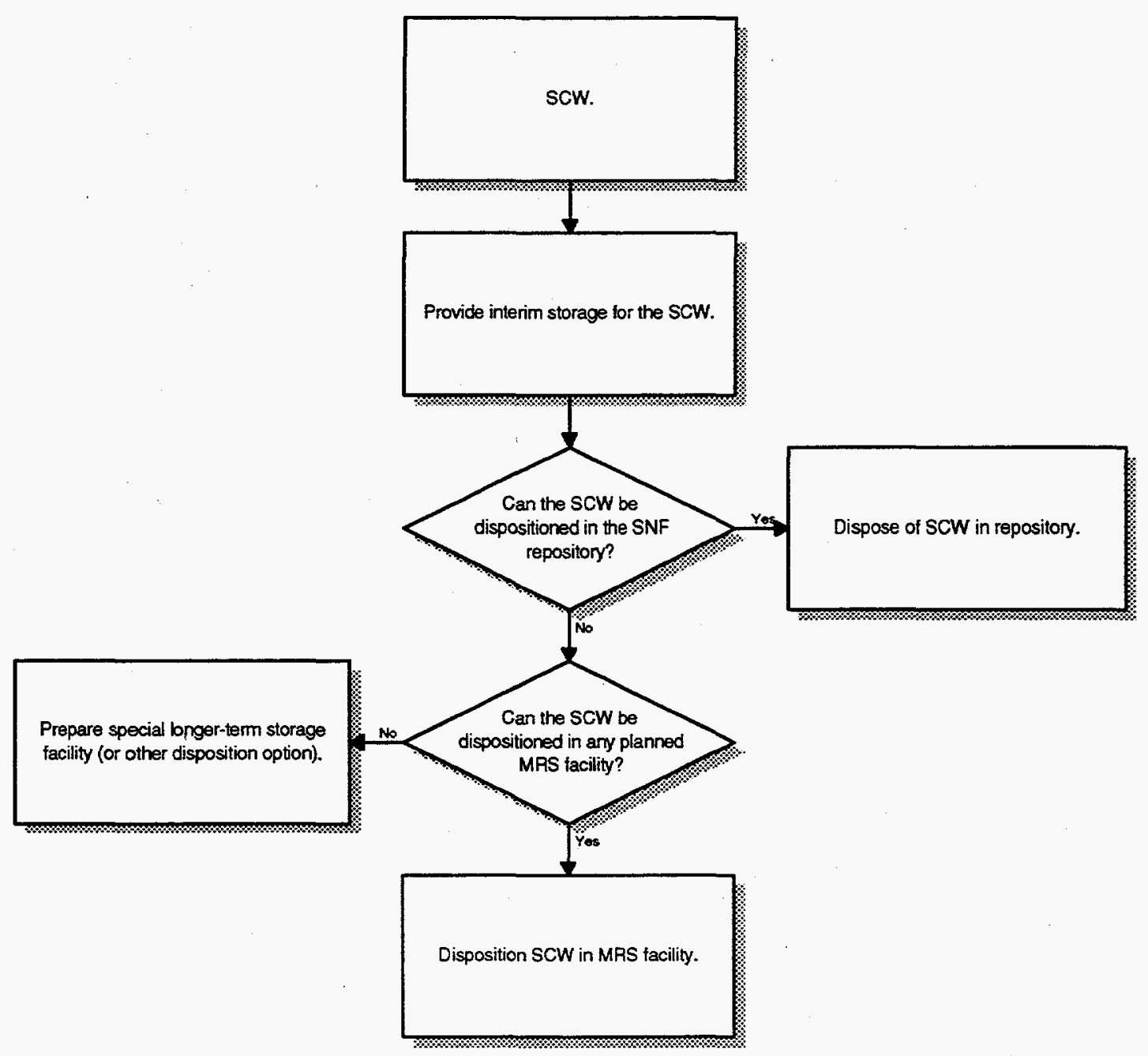

Fig. 3.8. Logical process for the disposition SCW at a repository or MSR (Chart 8). 


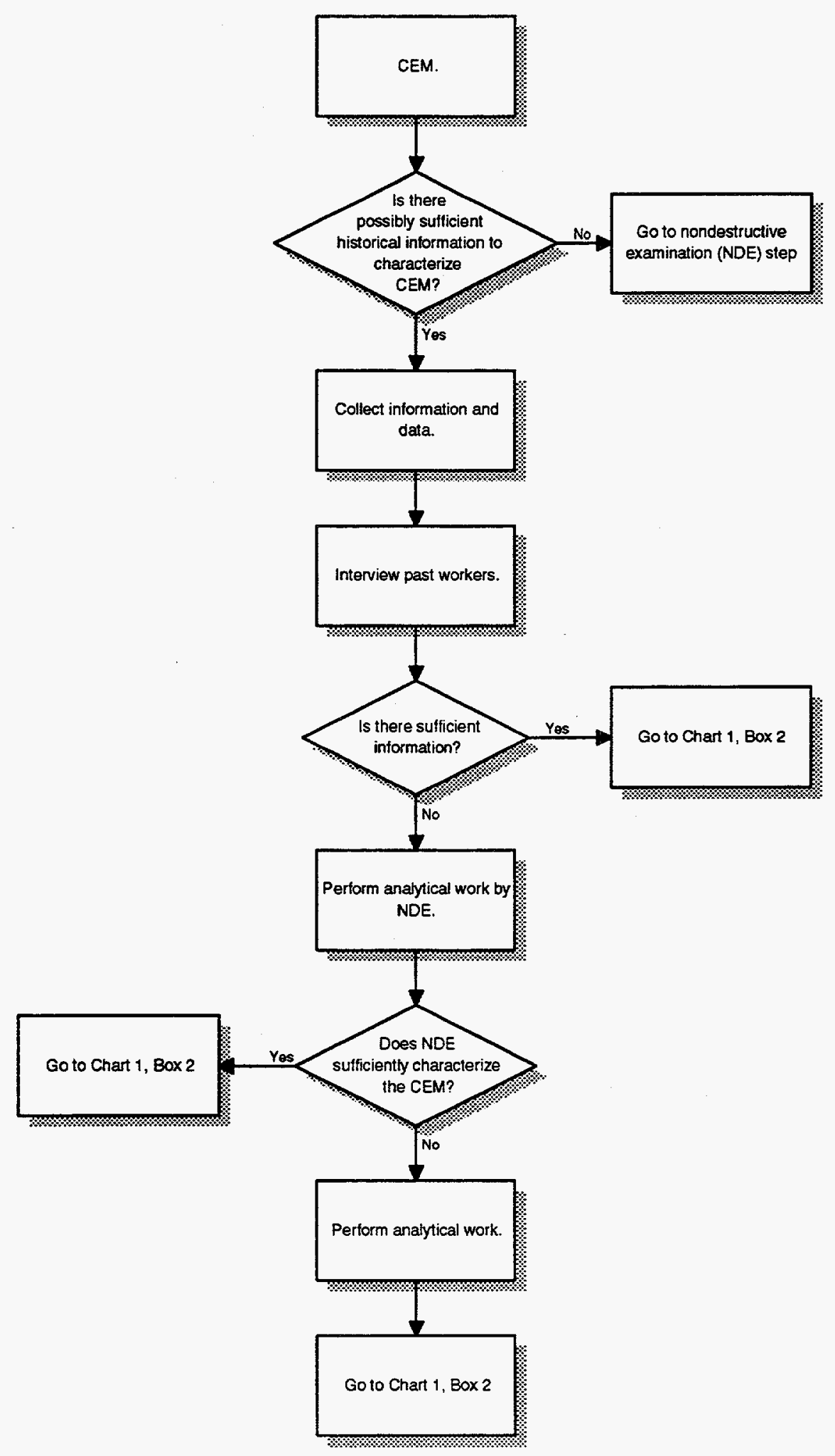

Fig. 3.9. Logical process to manage inadequately characterized CEM (Chart 9). 


\section{INVENTORY OF MATERIALS REVIEWED}

A large and diverse amount of waste from conducting operations are generated and stored at the three DOE facilities on the ORR (Fig. 4.1). In 1994, approximately $18,500 \mathrm{~m}^{3}$ of waste was stored at the three ORR sites, although the amount generated was less than one-third of that amount. ${ }^{4}$ The great majority of these wastes have a clearly defined future in terms of their management and ultimate disposition. Because some of these materials do not yet have a defined disposition path, further planning and analysis are required to define a path forward to disposition. This section defines the categories of CEM and provides information on the inventory of materials thought to have potential for becoming SCW. By comparison, a rough projection of SCW volumes for the year 2006 is in the range of 500 to $1000 \mathrm{~m}^{3}$, an amount equivalent to roughly $5 \%$ (by volume) of the total waste inventory for the ORR in 1994.

\subsection{CATEGORIES OF CEM (POTENTIALLY SCW)}

For this report, SCW is considered to be a material qualified as LLW and for which there is no identified path for disposition. The entire inventory of CEM was considered. However, disposition analyses show that much of the CEM can meet criteria for disposition, such that if the paths identified can be carried to conclusion, there will remain little actual SCW. Although there is no official definition of SCW, DOE has defined the following nine categories of such materials for planning purposes:

- Noncertifiable defense TRU waste

- Nondefense TRU waste

- GTCC waste

- Performance assessment limited waste

- Fuel and fuel debris-SNF

- Uncharacterized waste

- Excess nuclear material

- Radiation sources

- DOE-titled waste or material held by NRC licensees.

These nine categories are described in the following, and the descriptions are followed by summaries of material inventory on a plant-by-plant basis for the ORR. 
Waste Stored at the ORR In 1994

Total 18,950 $\mathrm{m}^{2}$

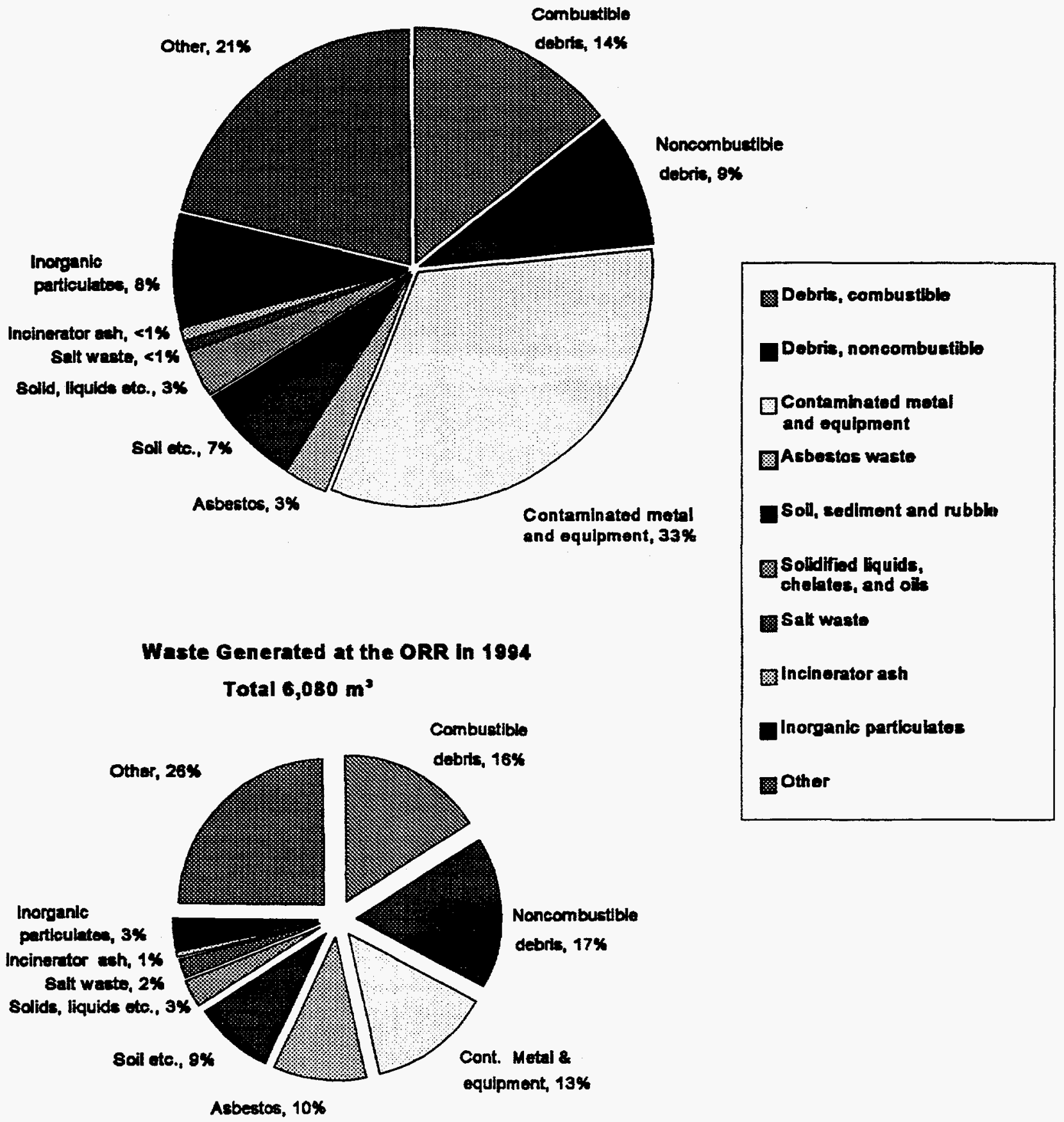

Fig. 4.1. Distribution of various LLW types generated and stored at the ORR in 1994 (ref. 2). 


\subsubsection{Noncertifiable Defense TRU Waste}

DOE TRU waste materials are defined (DOE Order 5820.2A, Attachment 2), on the basis of their activity content, as:

". . . without regard to source or form, waste that is contaminated with transuranic radionuclides with half-lives greater than 20 years and concentrations greater than $100 \mathrm{nCi} / \mathrm{g}$ at the time of assay."

Furthermore, TRU waste must be certified pursuant to the WIPP WAC, placed in interim storage, and sent to the WIPP when it becomes operational. The WIPP will accept only waste materials from DOE defense programs. However, some TRU waste materials generated from DOE defense programs may not be certifiable for disposal at the WIPP for various reasons, such as the inability of the waste to meet WIPP WAC, its unsuitability for the shipping container designated for transport, or security restrictions arising from the presence of classified shapes or materials. The acceptance criteria for the WIPP are given in Appendix B.

Hence, though there is a disposition plan for defense TRU waste in general, not all TRU waste at Oak Ridge may fully qualify to utilize that disposition pathway. Those materials that fall into the SCW category termed as noncertifiable defense TRU are depicted in Fig. 4.2.

\subsubsection{Nondefense TRU Waste}

TRU waste materials generated by other programs, termed nondefense TRU waste, do not have a longrange disposal alternative currently identified and are therefore SCW (Fig. 4.2). However, the CEM disposition program will treat all TRU waste as if it can be disposed of at the WIPP, because it is believed that there will be adequate room for the small incremental amount of nondefense waste involved and that waivers can and should be sought for it.

\subsubsection{GTCC LLW}

This category is used for certain wastes accepted by DOE from NRC licensees under the Low-Level Waste Policy Act of 1985 . LLW is radioactive waste not classified as high-level waste (HLW), TRU waste, SNF or by-product material. ${ }^{\dagger}$ High specific activity LLW-that is, having activity concentrations that exceed the Class $\mathrm{C}$ waste limits (Table 4.1)-are unsuitable for near-surface permanent disposal. No disposal alternative currently exists for these materials, so they are considered to be SCW.

\section{*As defined by 10 CFR Part 61.2.}

${ }^{\dagger}$ As defined in Sec. 11e.(2) of the Atomic Energy Act (uranium or thorium tailings and waste). 
ORNL/DWG 96-7688

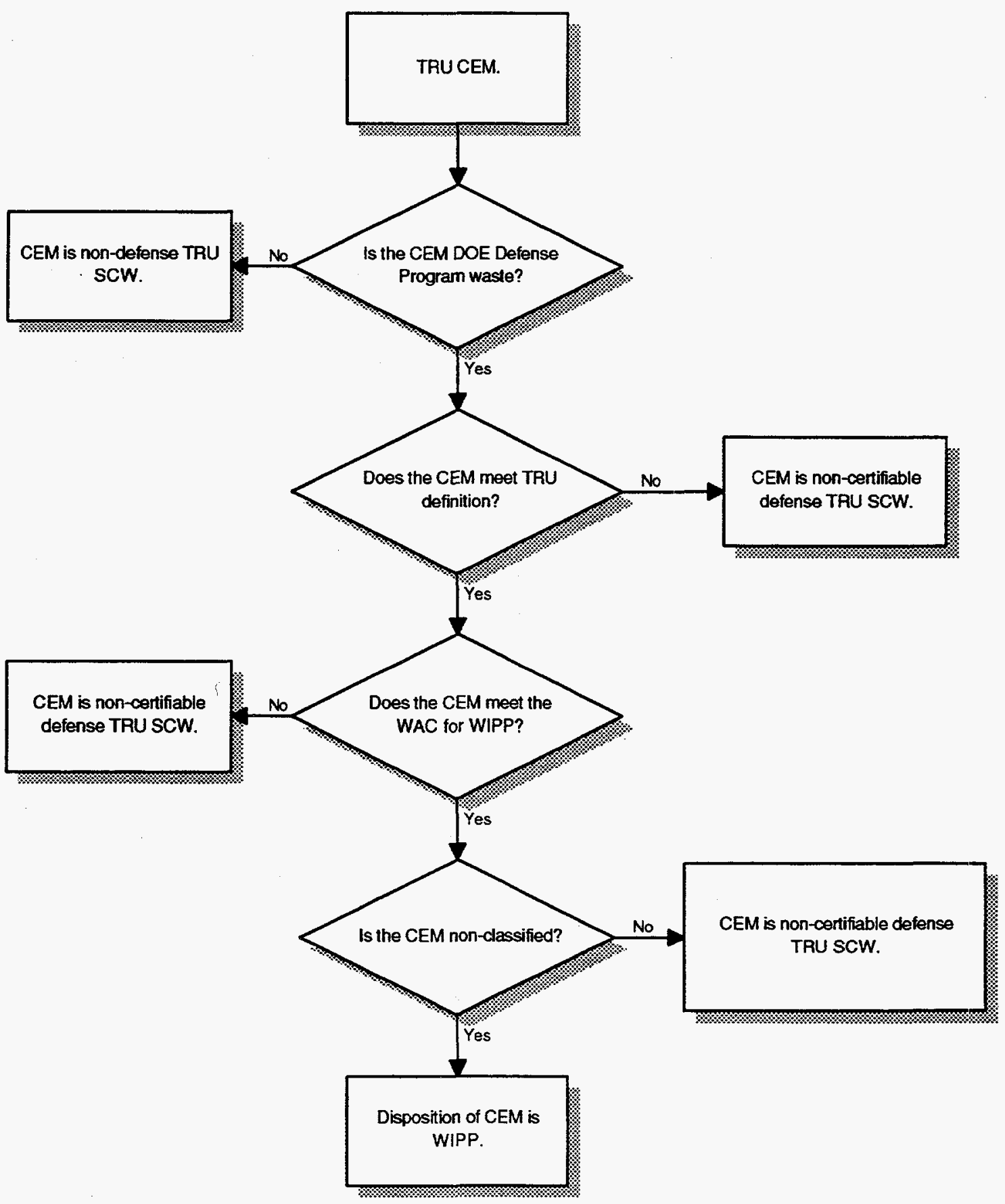

Fig. 4.2. Logical process for the determination of TRU categories of SCW. 


\subsubsection{Performance Assessment Limited Waste}

Materials in this category are similar in characteristics to those in the GTCC LLW category. Performance assessment limited waste is different in that it has been generated by DOE programs. The near-surface permanent disposal areas at ORNL have specific PALs-which are the radionuclide concentrations that are allowable in waste materials before environmental protection performance limits are exceeded. In the absence of another disposition option, such as an identified DOE off-site disposal site at which the PALs are not exceeded, these materials will be performance assessment limited SCW. The PALs for ORNL are given in Appendix B (Table B.1).

\subsubsection{SNF and Fuel Debris}

This planning category includes DOE SNF and fuel debris generated by research and development (R\&D) programs. SNF and fuel debris are defined as fuel, or parts of fuel, that have been withdrawn from a nuclear reactor following irradiation, but that have not been reprocessed to remove the constituent elements. Since DOE has established a national program for managing these materials, this category now has a defined disposition path and no longer constitutes SCW. Under the new program, the path forward for SNF and fuel debris involves interim regional storage at either the Savannah River Site (SRS) or INEEL. ORNL is in the process of cataloging and shipping these materials.

\subsubsection{Uncharacterized Waste}

Uncharacterized waste materials are radioactive materials identified as waste about which little is known. Yet, based on process knowledge or other factors (such as uncertainty of future packaging), it is believed that the waste will meet the definition of one of the other categories of SCW. Further characterization (i.e., to determine its material forms, approximate mass, and activity) and packaging of such waste are necessary, but may not currently be feasible. Some reasons why further characterization may be unfeasible include the following:

- excessive external dose rates deter characterization activities;

- contamination is concealed or inaccessible, such as in a vessel, sampling system, or other item of plant equipment that cannot be opened for sampling, but is suspected to contain a residual quantity of radionuclides that would be performance assessment limited SCW; or

- radionuclides are present which are not listed in the PALs table, but which may cause the waste to be SCW because of unusual radioactive or environmental performance characteristics.

Alternative paths forward for uncharacterized waste may indicate the need for further investigation to narrow the uncertainties about the material, the use of special examination facilities to provide better characterization while minimizing worker exposure, or interim or extended storage planning. 
Table 4.1. NRC limits for Class $\mathrm{C}$ low-level radioactive waste

\begin{tabular}{|c|c|c|}
\hline \multirow{2}{*}{$\begin{array}{l}\text { Nuclide } \\
\text { (Half-life) }^{\mathbf{a}}\end{array}$} & \multicolumn{2}{|c|}{ Concentration } \\
\hline & $\left(\mathrm{Ci} / \mathrm{m}^{3}\right.$ or $\left.\mu \mathrm{Ci} / \mathrm{cm}^{3}\right)$ & $(\mathrm{nCi} / \mathrm{g})$ \\
\hline \multicolumn{3}{|c|}{ Long-lived radionuclides ${ }^{b}$} \\
\hline${ }^{14} \mathrm{C}(5,730$ years $)$ & 8 & \\
\hline${ }^{14} \mathrm{C}$ in activated metal $(5,730$ years $)$ & 80 & \\
\hline${ }^{59} \mathrm{Ni}$ in activated metal $(75,000$ years $)$ & 220 & \\
\hline${ }^{94} \mathrm{Nb}$ in activated metal $(20,000$ years $)$ & 0.2 & \\
\hline${ }^{99} \mathrm{Tc}(214,000$ years $)$ & 3 & \\
\hline${ }^{129} 1(16,000,000$ years $)$ & 0.08 & \\
\hline Alpha-emitting TRUs (half-life exceeding years) & & 100 \\
\hline${ }^{241} \mathrm{Pu}\left(14\right.$ years $^{\mathrm{c}}$ & & 3,500 \\
\hline${ }^{242} \mathrm{Cm}(162.8 \mathrm{~d}){ }^{\mathrm{d}}$ & & 20,000 \\
\hline \multicolumn{3}{|c|}{ Short-lived radionuclides ${ }^{b}$} \\
\hline${ }^{63} \mathrm{Ni}$ (100 years) & 700 & \\
\hline${ }^{63} \mathrm{Ni}$ in activated metal ( 100 years) & 7,000 & \\
\hline${ }^{90} \mathrm{Sr}$ (29 years) & 7,000 & \\
\hline${ }^{137} \mathrm{Cs}$ (30 years) & 4,600 & \\
\hline
\end{tabular}

${ }^{2}$ Half-lives are from C. M. Lederer et al., Table of Isotopes, John Wiley and Sons, Inc., New York, 1978.

bLimits are for single radionuclides; for mixtures of radionuclides, limits are obtained by a sum-of-fractions rule separately for long- and short-lived radionuclides. The sum of fractions for either long- or short-lived radionuclides is determined by dividing each nuclide's concentrations by its Class $\mathrm{C}$ limit and adding the resulting values. If the sum exceeds 1 for either long- or short-lived radionuclides, the material is GTCC waste. Decays to a long-lived daughter product, ${ }^{237} \mathrm{~Np}\left(2.2 \times 10^{6}\right.$ years $)$.

${ }^{d}$ Decays to long-lived daughter products, ${ }^{238} \mathrm{Pu}$ (90 years) and ${ }^{234} \mathrm{U}\left(2.5 \times 10^{5}\right.$ years). 


\subsubsection{Excess Nuclear Materials}

DOE maintains special accountability for certain radioactive and stable isotopes that have strategic policy value. These are the following:

- DU,

- enriched uranium,

- ${ }^{233} \mathrm{U}$

- normal (natural) uranium,

- plutonium,

- ${ }^{241} \mathrm{Am}$,

- ${ }^{243} \mathrm{Am}$,

- curium,
- berkelium,

- ${ }^{252} \mathrm{Cf}$,

- ${ }^{6} \mathrm{Li}$,

- ${ }^{237} \mathrm{~Np}$,

- deuterium,

- tritium, and

- thorium.

Excess nuclear materials are scrap nuclear materials in quantities above an economic discard limit which are no longer useful to the present custodians, but which require processing that is not currently available to recover the useable nuclear materials. Examples of excess nuclear materials include plutonium isotopes, encapsulated neptunium, and uranium hexafluoride $\left(\mathrm{UF}_{6}\right)$ gas cylinders left over from isotope separation research.

\subsubsection{Sealed Radiation Sources}

Radiation sources are encapsulated (sealed) radioactive materials used to generate calibrated amounts of radiation. Eventually these sources become waste, and the concentrations of their radioactive materials determine whether they will be acceptable for disposal on-site as LLW. If their concentrations exceed the PALs for on-site disposal, such sources may be dispositioned off-site or may become SCW.

\subsubsection{DOE-Titled Waste or Material Held By Licensees}

This category includes radioactive waste or material for which a DOE organization holds responsibility, but which is held by licensees of the NRC (or agreement states). DOE has provided nuclear material to licensees through various mechanisms, including contracts, loans, leases, and grants for use in nuclear and related research fields. Both the materials and wastes are usually returned to DOE. This category would apply to waste materials (currently held at some location other than ORNL) which DOE intends to bring to ORNL, but which do not meet the criteria for permanent disposal at ORNL.

Currently, the predominant materials considered to be in this category are radioactive sources on loan through the Californium Loan Program. Under this program, NRC licensees (such as universities, research laboratories, and hospitals) or other DOE sites are loaned sealed sources of ${ }^{252} \mathrm{Cf}$, which, following its decay, comes back to ORNL with significant content of ${ }^{248} \mathrm{Cm}$, which is another valuable source material. Information on the sources currently on loan through the Californium Loan Program are summarized in Table 4.2 . 
Table 4.2 Sealed sources on loan through the Californium Loan Program

\begin{tabular}{|c|c|c|}
\hline Loanee type & $\begin{array}{l}\text { No. of } \\
\text { sources }\end{array}$ & $\begin{array}{c}\text { Quantity } \\
(\mu \mathrm{g})\end{array}$ \\
\hline Other DOE sites (e.g., national laboratories) & 138 & 56,574 \\
\hline Universities & 81 & 22,523 \\
\hline Military & 20 & 72,740 \\
\hline Hospitals & 16 & 126 \\
\hline $\begin{array}{l}\text { Other government agencics (e.g., National Institute of Standards } \\
\text { and Technology) }\end{array}$ & 14 & 1,950 \\
\hline Private sector & 10 & 82 \\
\hline Totals & 279 & 153,985 \\
\hline
\end{tabular}

\subsection{MATERIALS REVIEWED AT THE ORR}

Studies of SCW at the ORR have previously focused only on ORNL. In 1990, technical personnel from INEEL conducted a survey and study of the SCW at ORNL ${ }^{2}$; these were updated in $1995 .{ }^{3}$ Use has been made of the previous ORNL studies in this report. For the Y-12 Plant and the K-25 Site, however, no prior studies of SCW existed. Therefore, the information for these two sites is not as well developed as is that for ORNL. An investigation to improve SCW data for the ORR, especially for $\mathrm{Y}-12$ and $\mathrm{K}-25$ Sites, is currently underway.

As a starting point, this study has focused on the materials identified as a result of the Materials In Inventory (MIN) initiative. ${ }^{5}$ The purpose of the initiative is described as:

“. . an effort to locate surplus inventories of various materials that may no longer be needed for their original purpose and have no clearly identified future use."

The scope of the MIN initiative included the ORR facilities and the DOE facilities at Paducah and Portsmouth. The MIN report, ${ }^{5}$ developed with heavy reliance on previous studies, analyses, and existing documentation, provides valuable information on materials at the three ORR plants that could become SCW. Additional information was used from site-specific data bases, including data bases on LLW and radioactive sources.

The information described in the following is useful for our current purpose of examining potential paths forward for existing and future SCW. It is also valuable and necessary in developing strategies to better manage SCW. It is important to recognize, however, that the CEM inventory information presented in this report should not be considered as definitive. Further work is needed to accurately catalogue SCW at the three plants, especially for the $\mathrm{Y}-12$ and K-25 Sites. 


\subsubsection{Candidate Materials at ORNL}

The starting point for ORNL SCW was the ORNL data base, which originated from previous studies. The information in this data base, which contains over 1700 entries, is summarized in Table 4.3. Little is known about many of the items, and the table reflects considerable uncertainty. Based on what is known, performance assessment limited SCW is the predominant category, by mass, whereas radiation sources and other types of isotope inventories predominate based on curie content. Also, uncharacterized residues, scrap reactor internals, and waste and other materials generated from decontamination activities represent a substantial concern.

In addition to the ORNL SCW data base, information presented in this study was taken from the data base of loaned sources (Sect. 4.1.9) and from the MIN report, which defines ten categories of materials in storage that were not in use at the time of the survey, had not been used for a period of at least 1 year or more, and were not expected to be used within the next year. ${ }^{5}$ The ten material categories included in the MIN report are the following:

- SNF,

- scrap metals,

- enriched and natural uranium,

- DU,

- lithium,

- sodium,
- chemicals,

- plutonium and other Nuclear Materials

Management Safeguards System (NMMSS)-

tracked materials,

- lead, and

- weapons components.

SNF and lead are excluded from this report because they are no longer considered SCW. Weapons components at ORNL are not considered to be SCW.

The inventory of materials at ORNL based on the MIN report are summarized in Tables 4.4-4.10, including information on the types and amounts of scrap metal and equipment (Tables 4.4 and 4.5); depleted, enriched, and normal uranium (Tables 4.6-4.7); lithium, sodium, and some of their compounds (Table 4.8); excess chemicals (Table 4.9); and plutonium and other NMMSS materials (Table 4.10).

\subsection{MATERIALS AT THE Y-12 PLANT}

The inventory of materials, e.g., scrap metal, enriched uranium, lithium, and excess chemicals at the Y-12 Plant based on the MIN report is summarized in Tables 4.11-4.15. The sodium at $Y-12$ belongs to ORNL and was reported in the previous section. The DU inventory at the Y-12 Plant is confidential weaponsproduction-related information and may be obtained from the NMMSS Program Office at the Y-12 Plant. The NMMSS materials at $Y-12$ that exist in significant quantities include deuterium, thorium, and numerous radioactive sources used in various buildings. Inventory information on deuterium and thorium at the Y-12 Plant is classified. There exist about $3,000 \mathrm{~kg}$ of thorium-containing scrap from fuel elements. 
Table 4.3 Summary of information on SCW materials from the ORNL SCW data base

\begin{tabular}{|c|c|c|c|c|c|}
\hline $\begin{array}{l}\text { Material locations } \\
\text { (Buildings and sites) }\end{array}$ & Category & $\begin{array}{l}\text { No. of } \\
\text { containers }\end{array}$ & $\begin{array}{l}\text { Total weight } \\
(\mathrm{kg})\end{array}$ & $\begin{array}{l}\text { Total activity } \\
\text { (Ci) }\end{array}$ & Description \\
\hline 7827 & $\mathrm{ENM}^{a}$ & 1 & 23 & 0.00006 & Excess nuclear materials \\
\hline $\begin{array}{l}7879 \text { and other ORNL } \\
\text { building }\end{array}$ & Non-SCW & $>822$ & $>207,067$ & $>1,405,340$ & $\begin{array}{l}\text { Non-SCW of planning interest, such as } \\
\text { surplus isotope inventories }\end{array}$ \\
\hline $\begin{array}{l}7827,27822 \mathrm{~A}, 7841 \\
7842 \mathrm{~A}, 7900, \text { and } \\
\text { IWMF }^{b} \operatorname{Pad} 4\end{array}$ & $\begin{array}{l}\text { Performance } \\
\text { assessment } \\
\text { limited }\end{array}$ & 217 & $>1,728,538$ & $>398,358$ & $\begin{array}{l}\text { Waste that does not meet on-site PALs, } \\
\text { including scrap reactor internals from } \\
\text { HFIR }^{c}\end{array}$ \\
\hline $\begin{array}{l}7827 \text { and other ORNL } \\
\text { buildings }\end{array}$ & $\begin{array}{l}\text { Radiation } \\
\text { sources }\end{array}$ & $>19$ & $>2,598$ & $1,758,000$ & Various radiation sources \\
\hline $\begin{array}{l}3029,3525,3038 \\
351, \text { and } 3025 \mathrm{E}\end{array}$ & $\begin{array}{l}\text { Uncharacterized } \\
\text { residues }\end{array}$ & Unknown & Unknown & Unknown & $\begin{array}{l}\text { Residues from isotope production, spent } \\
\text { fuel examination, and research targets. }\end{array}$ \\
\hline $\begin{array}{l}3010,7500,7503, \text { and } \\
7700\end{array}$ & $\begin{array}{l}\text { Uncharacterized } \\
\text { scrap internals }\end{array}$ & Unknown & Unknown & Unknown & $\begin{array}{l}\text { Scrap reactor internals from BSR, } \\
\text { HRE, }^{e} \text { MSRE }^{\prime} \text {, and } \text { TSF }^{g}\end{array}$ \\
\hline $\begin{array}{l}7822 \mathrm{~J} \text { and liquid LLW } \\
\text { facilities }\end{array}$ & $\begin{array}{l}\text { Undetermined } \\
\text { SCW }\end{array}$ & Unknown & Unknown & Unknown & $\begin{array}{l}\text { SCW can be generated from } \\
\text { decontamination activities at storage } \\
\text { pads and other liquid LLW facilities }\end{array}$ \\
\hline
\end{tabular}

${ }^{a}$ ENM denotes excess nuclear material.

${ }^{b}$ IWMF denotes the Interim Waste Management Facility.

'HFIR denotes the High Flux Isotope Reactor.

${ }^{d}$ BSR denotes the Bulk Shielding Reactor.

${ }^{e} \mathrm{HRE}$ denotes the Homogeneous Reactor Experiment.

AMSRE denotes the Molten Salt Reactor Experiment. PALs denotes performance assessment limits.

${ }^{8}$ TSF denotes the Tower Shielding Facility. 
The radioactive sources at $\mathrm{Y}-12$ number close to one thousand. The sources are used in a variety of equipment such as radiation detection instruments and in operations processes. About $60 \%$ of these sources are in active use, while $40 \%$ are considered excess and are awaiting final disposition. Table 4.15 summarizes the source types in inventory at $\mathrm{Y}-12$.

\subsection{MATERIALS AT THE K-25 SITE}

The inventory of materials (e.g., scrap metal, scrap processing equipment, uranium, lithium, and excess chemicals) at the K-25 Site based on the MIN report is summarized in Tables 4.16-4.22. The NMMSS materials at K-25 consist of the three plutonium sources, as shown in Table 4.22.

Table 4.4 Scrap metal inventory at ORNL

(ref. 5)

\begin{tabular}{lc}
\hline Material & Quantity (t) \\
\hline Carbon steel & 1,240 \\
Stainless steel & 147 \\
Aluminum & 22 \\
Copper & 2 \\
\multicolumn{1}{c}{ Total } & 1,411 \\
\hline
\end{tabular}


Table 4.5 Surplus equipment scrap metal inventory at ORNL (ref. 5)

\begin{tabular}{|c|c|}
\hline Material & Quantity $\left(\mathrm{m}^{3}\right)$ \\
\hline \multicolumn{2}{|c|}{ Marketable metals } \\
\hline Beryllium & 15.808 \\
\hline Boron & 4.110 \\
\hline Cadmium & 0.160 \\
\hline Stainless steel & 0.100 \\
\hline Tin & 0.300 \\
\hline Graphite & 14.900 \\
\hline \multicolumn{2}{|c|}{ Other equipment } \\
\hline Concrete shielding & 287.000 \\
\hline Control plates & 1.000 \\
\hline Core support components & 2.000 \\
\hline Dummy fuel assemblies & 10.000 \\
\hline Equipment (used, machine shop) & 43.000 \\
\hline Fuel shipping casks & 3.000 \\
\hline Ion exchange resins & 2.380 \\
\hline Radioluminescent lights & 8.000 \\
\hline Reactor fuel racks & 1.170 \\
\hline Remote shear system & 70.000 \\
\hline Scrap equipment & 107.200 \\
\hline
\end{tabular}


Table 4.6 Excess DU ORNL (ref. 5)

\begin{tabular}{lc}
\hline Chemical-physical form & Quantity (kg) \\
\hline Oxide & 3 \\
Metal-billets & 82 \\
\hline
\end{tabular}

Table 4.7 Excess enriched and normal uranium at ORNL (ref. 5)

\begin{tabular}{|c|c|c|}
\hline \multirow{2}{*}{ Chemical-physical form } & \multicolumn{2}{|c|}{ Quantity (g) } \\
\hline & Element & Isotope \\
\hline \multicolumn{3}{|c|}{ Enriched uranium } \\
\hline Samples and standards & 206 & 200 \\
\hline Experimental capsules, elements, pins & 132 & 131 \\
\hline Metal & 187 & 175 \\
\hline Tetrafluoride products & 62 & 58 \\
\hline Oxides & 39 & 36 \\
\hline Fuel element and target fabrication & 6 & 6 \\
\hline \multicolumn{3}{|c|}{ Normal uranium } \\
\hline Oxide & 2 & 0 \\
\hline Metal & 6 & 0 \\
\hline
\end{tabular}


Table 4.8 Lithium hydride (LiH), Sodium ( $\mathrm{Na}$ ), potassium (K), and $\mathrm{NaK}$ at ORNL and ORNL facilities at Y-12 (ref. 5)

\begin{tabular}{|c|c|c|c|}
\hline Facility & Building No. & Material & Quantity (lb) \\
\hline TSF & 7708 & $\mathrm{LiH}$ & $77 \mathrm{ft}^{3}$ \\
\hline TSF & 7708 & $\begin{array}{l}\mathrm{LiH} \\
\text { contaminated } \\
\text { with }{ }^{60} \mathrm{Co}\end{array}$ & $22 \mathrm{ft}^{3}$ \\
\hline TSF & 7708 & $\mathrm{LiH}$ and $\mathrm{U}$ & $38 \mathrm{ft}^{3}$ \\
\hline TSF & 7708 & Tin sheet of $\mathrm{Li}$ & $.0013 \mathrm{ft}^{3}$ \\
\hline TSF & 7708 and pad & Na shields & 38,200 \\
\hline TSF & 7708 and pad & $\begin{array}{l}\text { Contaminated } \\
\text { Na shields }\end{array}$ & 66,500 \\
\hline TSF & 7708 and pad & $\begin{array}{l}\mathrm{Na} \text { shields with } \\
\text { activated cans }\end{array}$ & 4,540 \\
\hline TSF & 7708 & $\begin{array}{l}\mathrm{Na} \text { and } \mathrm{U} \\
\text { shields }\end{array}$ & 6,960 \\
\hline Heater test loop & $9201-3$ & $\mathrm{Na}$ & $<500$ \\
\hline $\begin{array}{l}\text { Potassium vapor } \\
\text { topping cycle }\end{array}$ & $9201-3$ & $\mathrm{~K}$ & $<100$ \\
\hline $\begin{array}{l}\text { Sodium boiling } \\
\text { test facility }\end{array}$ & $9201-3$ & $\mathrm{Na}$ & $<500$ \\
\hline $\begin{array}{l}\text { Thermal } \\
\text { hydraulic out- } \\
\text { of-reactor safety }\end{array}$ & $9201-3$ & $\mathrm{Na}$ & 2,400 \\
\hline $\begin{array}{l}\text { Thermal } \\
\text { transient test }\end{array}$ & $9201-3$ & $\mathrm{Na}$ & 5,500 \\
\hline $\begin{array}{l}\text { SNAP-10 } \\
\text { Reactor }\end{array}$ & $9720-5$ & NaK & $<100$ \\
\hline
\end{tabular}


Table 4.9 Excess chemicals at ORNL (ref. 5)

\begin{tabular}{lc}
\hline \multicolumn{1}{c}{ Type } & Quantity $\left(\mathrm{m}^{3}\right)$ \\
\hline Acetic acid, glacial & 0.0005 \\
Ammonium & 0.757 \\
${ }^{90} \mathrm{Sr}$ fluoride & 0.100 \\
Zinc bromide & 11.69 \\
\hline
\end{tabular}

Table 4.10 Plutonium and other NMMSS tracked materials at ORNL (ref. 5)

\begin{tabular}{|c|c|c|}
\hline \multirow{2}{*}{ Chemical-physical form } & \multicolumn{2}{|c|}{ Quantity (g) } \\
\hline & Element & Isotope \\
\hline \multicolumn{3}{|l|}{${ }^{238} \mathbf{P u}$} \\
\hline Dioxide-solid & 821.6 & 677.8 \\
\hline \multicolumn{3}{|l|}{${ }^{239.241} \mathbf{P u}$} \\
\hline Dioxide-solid & 286 & 253 \\
\hline Metal-solid & 152 & 116 \\
\hline Samples and standards & 89 & 78 \\
\hline Plutonium-beryllium sources & 80 & 79 \\
\hline \multicolumn{3}{|l|}{${ }^{242} \mathbf{P u}$} \\
\hline Experimental capsules, elements, and pins & 8 & 7 \\
\hline Metal_billets product & 9 & 9 \\
\hline \multicolumn{3}{|l|}{${ }^{241} \mathrm{Am}$} \\
\hline Dioxide & 22 & 19 \\
\hline \multicolumn{3}{|l|}{${ }^{233} \mathbf{U}$} \\
\hline Various & $1,383 \mathrm{~kg}$ & $423 \mathrm{~kg}$ \\
\hline \multicolumn{3}{|l|}{${ }^{237} \mathrm{~Np}$} \\
\hline Oxide & 16 & \\
\hline Sample & 2 & \\
\hline \multicolumn{3}{|l|}{ Th } \\
\hline Samples and standards & $2 \mathrm{~kg}$ & \\
\hline Oxides & $2 \mathrm{~kg}$ & \\
\hline Nitrate compound & $1 \mathrm{~kg}$ & \\
\hline Metal & $13 \mathrm{~kg}$ & \\
\hline
\end{tabular}


Table 4.11 Scrap metal inventory at Y-12 (ref. 5)

\begin{tabular}{lc}
\hline Material & Y-12 Plant $(t)$ \\
\hline Carbon steel & 10,490 \\
Stainless stecl & 752 \\
Aluminum & 42 \\
Copper & 48 \\
$\quad$ Total & 11,332 \\
\hline
\end{tabular}

Table 4.12 Excess enriched uranium at the Y-12 Plant (ref. 5)

\begin{tabular}{lc}
\hline Chemical-physical form & Quantity $(t)$ \\
\hline \multicolumn{1}{c}{ Highly enriched uranium } \\
Uranium metal & 147.9 \\
Uranium oxide & 18.8 \\
Alloys, nitrates, and other forms & 2.2 \\
& Low enriched uranium \\
Metals, alloys, oxides, and nitrates & 3.0 \\
Total & 171.9 \\
\hline
\end{tabular}


Table 4.13 Types of bulk lithium material in inventory at the ORR (ref. 5)

\begin{tabular}{|c|c|c|}
\hline $\begin{array}{l}\text { Physical/chemical } \\
\text { form of lithium }\end{array}$ & Isotopic composition & $\begin{array}{l}\text { Current storage } \\
\text { locations }\end{array}$ \\
\hline $\begin{array}{l}\text { Virgin lithium hydroxide } \\
\text { monohydrate }(\mathrm{LiOH})\end{array}$ & $\begin{array}{c}92.5 \text { wt } \%{ }^{7} \mathrm{Li} \\
7.5 \text { wt } \%{ }^{6} \mathrm{Li}\end{array}$ & 17 vaults at $K-25$ Site \\
\hline Depleted LiOH & $\begin{array}{l}{ }^{6} \mathrm{Li} \mathrm{wt} \%<2.5 \\
97.5 \text { wt } \%{ }^{7} \mathrm{Li}\end{array}$ & $\begin{array}{l}\text { Small quantities at the } \\
\text { Y-12 Plant and the } \\
\text { K-25 Site }\end{array}$ \\
\hline \multirow[t]{2}{*}{$\begin{array}{l}\text { Strategic }{ }^{6} \mathrm{Li} \text { (in various } \\
\text { chemical forms) }\end{array}$} & $60<{ }^{6} \mathrm{Li}$ wt $\%<95.5$ & $\begin{array}{l}2 \text { vaults at the } K-25 \\
\text { Site }\end{array}$ \\
\hline & & $\begin{array}{l}\text { Lithium storage } \\
\text { facilities at the } \mathrm{Y}-12 \\
\text { Plant }\end{array}$ \\
\hline
\end{tabular}

aThe quantity of strategic lithium is classified. The material is tracked through NMMSS procedures established in DOE Order 5633.5, Nuclear Materials

Reporting and Data Submissions, for level-4 materials. 
Table 4.14 Excess chemicals and chemicals of special concern at Y-12 (ref. 5)

\begin{tabular}{|c|c|c|}
\hline Chemicals & Number or amounts & Unit of Measure \\
\hline Calcium metal & 133 & 1-gal drum \\
\hline Methyl chloroform & 43 & 55-gal drum \\
\hline Nitric acid & 138 & Bottles \\
\hline Adhesive contact & 105 & Containers \\
\hline Adhesive Quick-Set & 25 & Bottles \\
\hline Acid hydrofluoric & 28 & Bottles \\
\hline Potassium hydroxide & 880 & Pounds \\
\hline Yttrium oxide & 78 & Pounds \\
\hline Plating solution & 19 & Drums \\
\hline Nickel enthrone $-415 \mathrm{C}$ & 240 & Gallons \\
\hline Sieve materials & 23 & Drums \\
\hline Acid nitric $9598-3$ & 138 & Bottles \\
\hline Tetrachloroethylene & 15 & Drums \\
\hline Mercury & 38,162 & (a) 76 lb/flask \\
\hline \multicolumn{3}{|c|}{ Chemicals of special concern } \\
\hline Sulfuric acid & $\begin{array}{l}\text { Average amounts between } \\
100,000-999,999\end{array}$ & $\begin{array}{l}\text { Above ground tanks, } \\
\text { tanks inside } \\
\text { building, } \\
\text { nonmetallic } \\
\text { drums, bottles }\end{array}$ \\
\hline Hydrochloric acid & $\begin{array}{l}\text { Average amounts between } \\
100,000-999,999\end{array}$ & $\begin{array}{l}\text { Above ground tank, } \\
\text { nonmetallic } \\
\text { drums, bottles }\end{array}$ \\
\hline Sodium hypochlorite & $\begin{array}{l}\text { Average amount between } \\
10,000-99,999\end{array}$ & $\begin{array}{l}\text { Above ground tank, } \\
\text { drums and } \\
\text { bottles }\end{array}$ \\
\hline Beryllium and compounds & $\begin{array}{l}\text { Average amount between } \\
10,000-99,999\end{array}$ & $\begin{array}{l}\text { Steel drums, bags, } \\
\text { glass and plastic } \\
\text { bottles }\end{array}$ \\
\hline
\end{tabular}


Table 4.15 Radioactive source types at the Y-12 Plant

\begin{tabular}{lcc}
\hline Isotope & No. of sources & $\mathrm{Ci}$ \\
${ }^{235} \mathrm{U}$ & 330 & $1.40 \mathrm{E}-02$ \\
${ }^{137} \mathrm{Cs}$ & 179 & $4.48 \mathrm{E}+00$ \\
${ }^{238} \mathrm{U}$ & 143 & $1.79 \mathrm{E}-02$ \\
${ }^{241} \mathrm{Am}$ & 98 & $1.05 \mathrm{E}+02$ \\
${ }^{63} \mathrm{Ni}$ & 73 & $9.17 \mathrm{E}-01$ \\
${ }^{228-232} \mathrm{Th}$ & 40 & $5.57 \mathrm{E}-04$ \\
${ }^{238-239} \mathrm{Pu}$ & 20 & $5.59 \mathrm{E}+01$ \\
${ }^{90} \mathrm{Sr}$ & 19 & $1.40 \mathrm{E}-02$ \\
${ }^{133} \mathrm{Ba}$ & 17 & $3.48 \mathrm{E}-02$ \\
${ }^{252} \mathrm{Cf}$ & 16 & $6.03 \mathrm{E}-03$ \\
${ }^{109} \mathrm{Cd}$ & 14 & $5.75 \mathrm{E}-03$ \\
${ }^{60} \mathrm{Co}$ & 14 & $1.72 \mathrm{E}+01$ \\
${ }^{169} \mathrm{Yb}$ & 14 & $2.22 \mathrm{E}-01$ \\
${ }^{153} \mathrm{Gd}$ & 13 & $1.62 \mathrm{E}-02$ \\
${ }^{3} \mathrm{H}$ & 12 & $1.15 \mathrm{E}+01$ \\
${ }^{147} \mathrm{Pm}$ & 9 & $4.74 \mathrm{E}-03$ \\
${ }^{226} \mathrm{Ra}$ & $1.20 \mathrm{E}-04$ \\
${ }^{234} \mathrm{U}$ & 5 & $7.29 \mathrm{E}-07$ \\
${ }^{237} \mathrm{~Np}$ & 1 & $7.52 \mathrm{E}-07$ \\
${ }^{204} \mathrm{Tl}$ & 1 & $2.57 \mathrm{E}-02$ \\
${ }^{207} \mathrm{Bi}$ & 1 & $6.55 \mathrm{E}-05$ \\
${ }^{55} \mathrm{Fe}$ & $1.62 \mathrm{E}-02$ \\
${ }^{192} \mathrm{Ir}$ & 1 & $5.23 \mathrm{E}+00$ \\
${ }^{151} \mathrm{Sm}$ & 1 & $2.31 \mathrm{E}-02$ \\
${ }^{99} \mathrm{Tc}$ & $6.16 \mathrm{E}-04$ \\
${ }^{233} \mathrm{U}$ & 3 & $3.55 \mathrm{E}-07$ \\
\hline $\mathrm{Total}$ & $1.01 \mathrm{E}+02$ \\
\hline & 1032 & \\
\hline & & \\
\hline
\end{tabular}


Table 4.16 Scrap metal inventory at the K-25 Site (ref. 5)

\begin{tabular}{lc}
\hline Material & Quantity (t) \\
\hline Carbon steel & 35,318 \\
Stainless steel & 114 \\
Aluminum & 1,211 \\
Copper & 46 \\
Monel & 10 \\
Total & 36,699 \\
\hline
\end{tabular}

Table 4.17 Process equipment scrap metal inventory at the K-25 Site (ref. 5)

\begin{tabular}{lr}
\hline Material & Quantity $(\mathrm{t})$ \\
\hline Ferrous metals/steel & 128,700 \\
Aluminum, copper & 8,500 \\
Copper wire, tubing, & 17,600 \\
valves & \\
Monel pipe, valves & 1,700 \\
Nickel & 22,100 \\
Miscellaneous & 123,300 \\
Total & 301,900 \\
\hline
\end{tabular}


Table 4.18 Inventory of DU at the K-25 Site and other Oak Ridge Operations gaseous diffusion plants (ref. 5)

\begin{tabular}{lcccc}
\hline & $\begin{array}{c}\text { K-25 } \\
\text { Site }\end{array}$ & $\begin{array}{c}\text { Portsmouth } \\
\text { GDP }\end{array}$ & $\begin{array}{c}\text { Paducah } \\
\text { GDP }\end{array}$ & Total \\
\hline Metric tons of $\mathrm{UF}_{6}$ & 36,716 & 110,132 & 231,536 & 378,384 \\
\hline
\end{tabular}

Table 4.19 Excess chemicals and chemicals of special concern at the K-25 Site (ref. 5)

\begin{tabular}{lc}
\hline Type & Amount \\
\hline Epoxy resins & $3,083,875 \mathrm{lb}$ \\
Ferric sulfate (Ferri-floc) & $6,000 \mathrm{lb}$ \\
C816/B437 Coolant & $32,000 \mathrm{gal}$ \\
\hline
\end{tabular}


Table 4.20 Description of enriched and natural uranium at the K-25 Site (ref. 5)

\begin{tabular}{|c|c|c|c|}
\hline Material & Container & $\begin{array}{l}\text { No. of } \\
\text { items }\end{array}$ & Physical location \\
\hline Normal UF 6 & $\begin{array}{l}\text { Cylinders }(2.5,10, \text { and } 14 \text { ton }) 8 \\
\text { and } 12 \text { in. }(>100 \mathrm{lb})\end{array}$ & $\begin{array}{l}66 \\
79\end{array}$ & $\begin{array}{l}\text { Cylinder yards and in } \mathrm{K}-25 \\
\text { building basement storage } \\
\text { area } \\
\text { 9A Vault }\end{array}$ \\
\hline $\begin{array}{l}\text { Enriched } \mathrm{UF}_{6} \\
\quad \text { (maximum } \\
\text { enrichment 4.5\%) }\end{array}$ & $\begin{array}{l}\text { Cylinders ( } 2.5,10 \text {, and } 14 \text { ton) } 8 \\
\text { and } 12 \text { in. }\end{array}$ & 646 & Cylinder yards \\
\hline $\begin{array}{l}\mathrm{K}-25 \text { Building-in } \\
\text { special nuclear } \\
\text { materials holdup }\end{array}$ & Process piping and equipment & 17,709 & $\begin{array}{l}\text { Within the K-25 Building } \\
\text { restricted access area }\end{array}$ \\
\hline $\begin{array}{l}\text { LEU in process } \\
\text { building holdup }\end{array}$ & Process piping and equipment & 95 & $\mathrm{~K}-25$ and $\mathrm{K}-29$ buildings \\
\hline $\begin{array}{l}\text { Centrifuge and atomic } \\
\text { vapor laser isotope } \\
\text { separation }\end{array}$ & $\begin{array}{l}\mathrm{UF}_{6} \mathrm{IS}, 2.5,5 \text {, and } 12 \mathrm{in} . \\
\text { cylinders; } 7 \text { and } 11 \mathrm{~kg} \mathrm{DU} \\
\text { dampers }\end{array}$ & 96 & $\begin{array}{l}\text { K-25 building withdrawal } \\
\text { alleys, K-101, K-1200, } \\
\text { K-1210, K-1220, K-1035 }\end{array}$ \\
\hline $\begin{array}{l}\text { Items held by } \\
\text { laboratories (e.g. } \\
\text { UF }_{6} \text { metal, alumina) }\end{array}$ & $\begin{array}{l}\text { Material in individual items } \\
\text { (including source material } \\
\text { for experiments, cold traps, } \\
\text { etc.) }\end{array}$ & 98 & K-1004L \\
\hline Fuel pins & Fuel pins in wooden crates & $\begin{array}{l}35 \text { wooden } \\
\text { crates }\end{array}$ & $\begin{array}{l}\text { Secure storage area in the } \\
\text { basement of the } K-25 \\
\text { building }\end{array}$ \\
\hline $\begin{array}{l}\text { Items in use or held for } \\
\text { use by operating } \\
\text { areas }\end{array}$ & $\begin{array}{l}\text { Small source cylinders, cold } \\
\text { traps, chemical traps, } \\
\text { individual items of process } \\
\text { piping or equipment }\end{array}$ & 5 & $\begin{array}{l}\text { Buildings K-1004D, K-1131, } \\
\text { K-1006 }\end{array}$ \\
\hline Sources and standards & $\begin{array}{l}\text { Sealed sources, small jars with } \\
\text { standards, olher matcrials } \\
\text { used by } \mathrm{NDA}^{\mathrm{a}} \text { as reference or } \\
\text { standard materials }\end{array}$ & 86 & $\begin{array}{l}\text { Buildings K-1030, K-1025A, } \\
\text { K-1025D }\end{array}$ \\
\hline $\begin{array}{l}\text { Individual items of } \\
\text { process equipment } \\
\text { and piping or } \\
\text { related materials } \\
\text { held in storage }\end{array}$ & $\begin{array}{l}\text { Section of pipe, valves, or other } \\
\text { items of equipment }\end{array}$ & 123 & $\begin{array}{l}\text { Buildings K-1420, K-33, } \\
\mathrm{K}-31, \mathrm{~K}-29, \mathrm{~K}-27, \mathrm{~K}-25\end{array}$ \\
\hline
\end{tabular}

${ }^{2}$ NDA is a measurement technique that can provide mcasurements of nuclear materials without altering their chemical or physical form. 
Table 4.21 Current storage locations and inventory for bulk lithium at K-25 (ref. 5)

\begin{tabular}{|c|c|c|}
\hline Physical/chemical form & Location and inventory & Basis of inventory \\
\hline Virgin $\mathrm{LiOH}$ & $\begin{array}{l}23,594,520 \mathrm{lb} \text { in } 17 \text { vaults in } \\
\mathrm{K}-25 \text { building at K-25 Site } \\
\text { (approximate) }\end{array}$ & $\begin{array}{l}\text { Count based on repackaging } \\
\text { effort completed in late } 1980 \mathrm{~s}\end{array}$ \\
\hline $\begin{array}{l}\text { Strategic lithium (in various } \\
\text { chemical forms) }\end{array}$ & $\begin{array}{r}\text { Quantity classified; material } \\
\text { stored at } Y-12 \text { and } \mathrm{K}-25\end{array}$ & $\begin{array}{l}\text { Material tracked through } \\
\text { NMMSS procedures } \\
\text { established in DOE Order } \\
5633.5, \text { Nuclear Materials } \\
\text { Reporting and Data } \\
\text { Submissions, for level-4 } \\
\text { materials }\end{array}$ \\
\hline
\end{tabular}

Table 4.22 Plutonium inventory at the K-25 Site (ref. 5)

\begin{tabular}{ccccc}
\hline Material & Quantity $(\mathrm{g})$ & Curies & Container & Building \\
\hline${ }^{238} \mathrm{Pu} /$ beryllium & 27.8 & 1.7 & $\begin{array}{c}\text { 15-gal drum, paraffin lined with } \\
\text { steel pipe annulus for holding } \\
\text { sealed capsule containing } \\
\text { plutonium powder }\end{array}$ & K-1025D \\
${ }^{239} \mathrm{Pu} /$ beryllium & 0.71 & 0.044 & $\begin{array}{c}55 \text {-gal outer drum, containing } \\
\text { several inner containers with } \\
\text { plutonium in a quart-sized metal } \\
\text { can, paraffin lined with annulus } \\
\text { for plutonium capsule }\end{array}$ & K-1025D \\
${ }^{238} \mathrm{Pu} /$ lithium & 2.2 & 0.025 & $\begin{array}{l}\text { 30-gal drum, paraffin lined with } \\
\text { annulus containing the sealed } \\
\text { plutonium capsule }\end{array}$ & K-1025D \\
\hline
\end{tabular}




\section{PRELIMINARY ANALYSIS OF DISPOSITION OF CANDIDATE EQUIPMENT AND MATERIALS IN THE DATA BASES}

Preliminary dispositions for the CEM in the data bases have been made using the logic presented in Sect. 3 and the CEM inventory described in Sect. 4. The results presented in this section provide needed guidance for CEM management and SCW planning. Dispositions were made on the basis of information and data which, in many cases, were not sufficiently definitive and complete. Also, none of the dispositions have been discussed with the managers and operators of various facilities and programs nor with oversight personnel who must concur on the disposition paths in many instances (e.g., transportation management). Thus, the disposition paths given by this analysis should be treated as an approximation of what could be possible; they represent a starting point for a more detailed consideration of the path forward to resolution of management issues related to each of the CEM items.

Also, in anticipation of the fact that many organizations have CEM that are no longer needed for missions, guidance was prepared on the transfer of excess radioactive materials and contaminated government property. The guidance is presented as Appendix C.

\subsection{PATH-FORWARD ANALYSIS USING THE OVERALL CHART (CHART 1)}

Figures 5.1 and 5.2 present the disposition of all of the CEM in the data bases. There are 2,996 items in the data base representing CEM from ORNL, Y-12, and K-25. About two-thirds of the items are sources. The other items are materials and equipment, both contaminated and uncontaminated.

As can be seen in Fig. $5.1, \sim 12 \%$ of the items can probably be reused. About $25 \%$ meet the definition of materials or wastes that are the responsibility of in-progress funded programs. About $35 \%$ of the CEM are under the performance assessment limits for near-surface disposal at ORR. This fraction could be larger, considering previous and future decay of constituent isotopes in the CEM. Up to $21 \%$ could be dispositioned at other sites, primarily the NTS, the HCWF, and the WESF, assuming that the materials would meet the detailed WAC. Special containers are required by WESF, for example, for cesium or strontium materials.

No material was dispositioned to paths for recycle and processing or for coprocessing or subsequent processing because other means of disposition were available. In fact, much of the CEM may need to be processed further for economical and feasible disposal. Currently, such processing is of concern to many of the programs. For example, ${ }^{252} \mathrm{Cf}$ sources, which number more than 200, were dispositioned to the Radiochemical Engineering Development Center (REDC) of ORNL, because the decayed sources are a good starting point for production of future

sources. The program for ${ }^{252} \mathrm{Cf}$ would do the recycling. Thus, it shows up in Path 2 (Reuse), not in Path 4. This assumes the desirability and capability to recycle specific materials-an assumption 
which should be examined further in cooperation with operators and program personnel who would approve the recycle of the materials from the californium sources.

In the pie chart for Path 1 (Fig. 5.1), 7\% of the CEM is represented as uncharacterized. Much of this is projected and existing materials from components of reactors and processing facilities. In some cases, these are materials that were previously nonradioactive, but that have become activated by neutron-irradiation, thus producing certain highly radioactive nuclides within the materials and equipment. In other cases, the CEM is contaminated by radioactive nuclides. More detailed analysis of the data bases and the type of contamination will allow classification of many of these items according to a proper path forward.

Almost none of the CEM were dispositioned as SCW. The 1.5 items estimated (Fig. 5.2) results from one item with an assigned probability of $100 \%$ and another item with an assigned probability of 50\%. Some of the uncharacterized CEM may yet be defined as SCW.

ORNL/DWG 96-7226

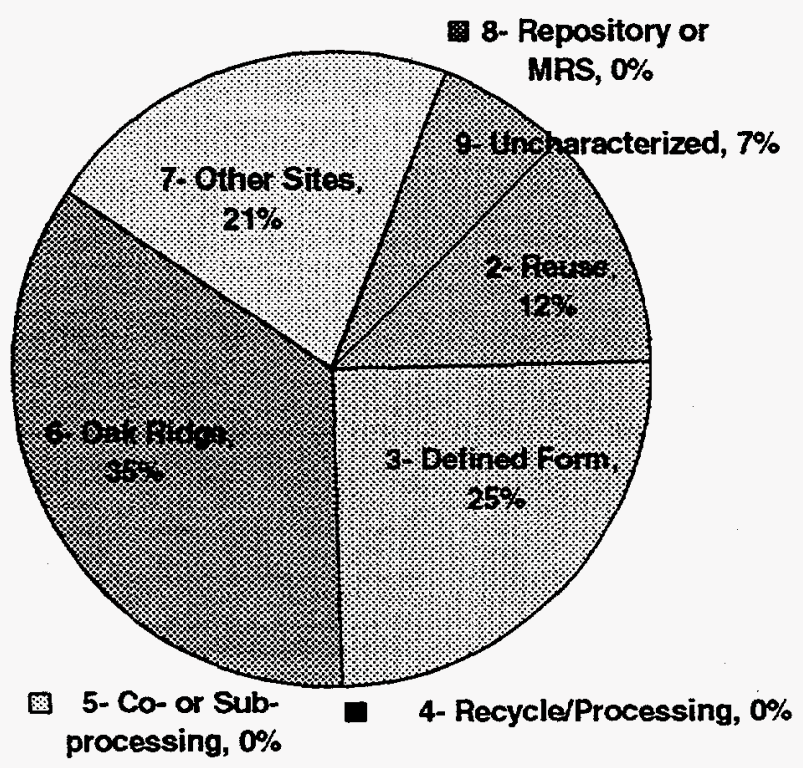

Fig. 5.1. Disposition of CEM by Chart 1 (percentage overall based on number of items). 


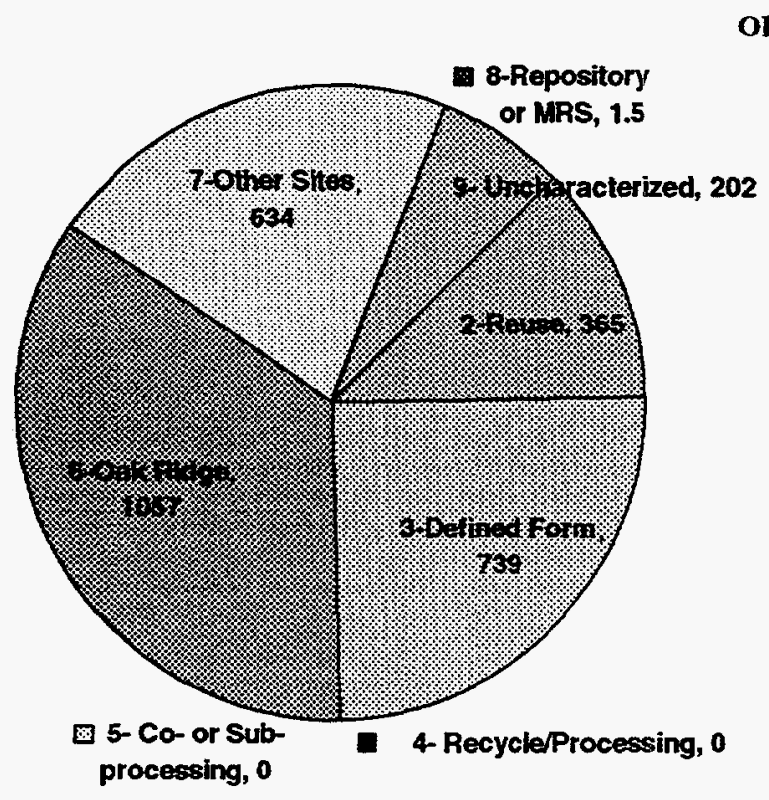

Fig. 5.2. Disposition of CEM by Chart 1 -overall (number of items).

\subsection{DISPOSITION OF CEM BY REUSE AND RECYCLE BY OTHERS (CHART 2)}

Figures 5.3 and 5.4 show the disposition of the CEM for reuse and recycle by others (12\% of total CEM). The REDC at ORNL would be the recipient of much of the material to be reused or recycled (62\%). These materials would be the ${ }^{252} \mathrm{Cf}$ sources (loaned and in inventory) and a few other isotopes of interest for isotope production. About $18 \%$ would be reused or recycled at other DOE facilities, particularly LANL for neutron generator sources. Most of the commercial disposition is for nonradioactive surplus materials, such as bulk chemicals and materials.

\subsection{DISPOSITION OF CEM BY DEFINED FORM (CHART 3)}

Much of the material (25\% of total CEM) is the responsibility of other programs. Disposition of this material is shown in Figs. 5.5 and 5.6. About 80\% of the items are dispositioned to the $\mathrm{Pu}{ }^{233} \mathrm{U}$ management program or to the TRU Waste Management Program. Many items are slated for management by the SNF Management Program or the programs for SNM, LLW, or DU. A few thorium items cannot go to disposal at the ORR, and there is currently no program for their disposition. 


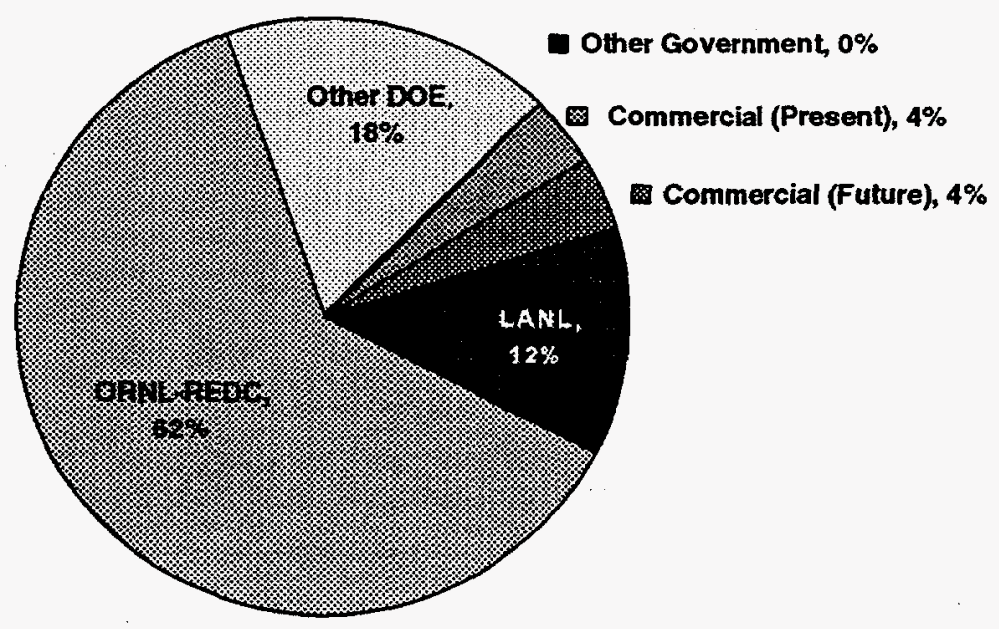

Fig. 5.3. Disposition of CEM by Chart 2-reuse (percentage based on number of items).

ORNL DWG 96-7229

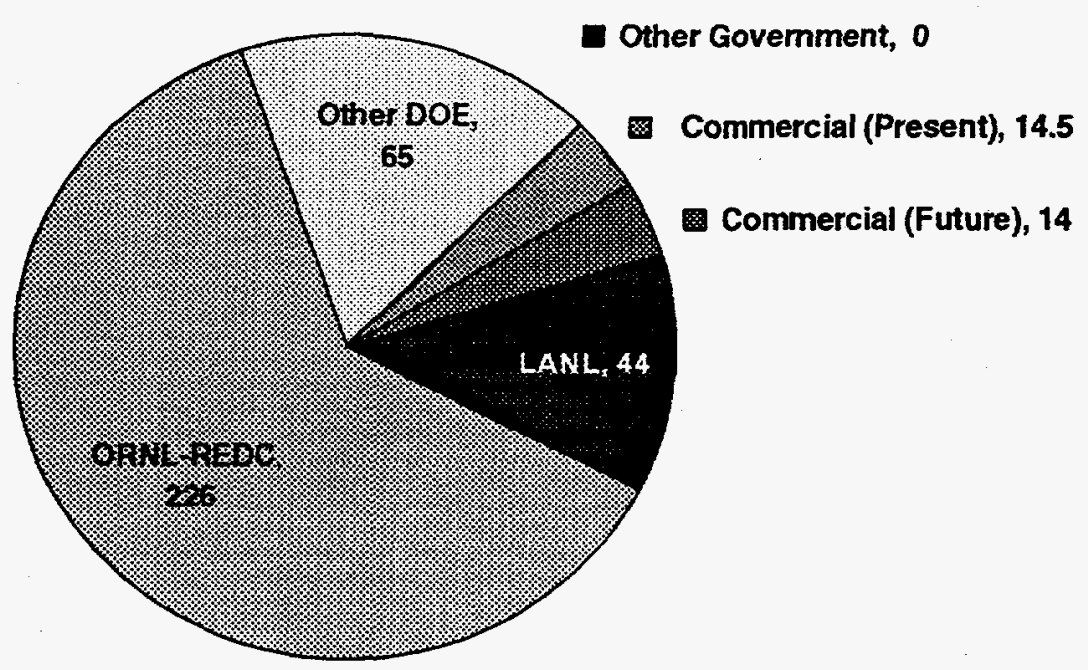

Fig. 5.4. Disposition of CEM by Chart 2-reuse (number of items). 
ORNL/DWG 96-7230

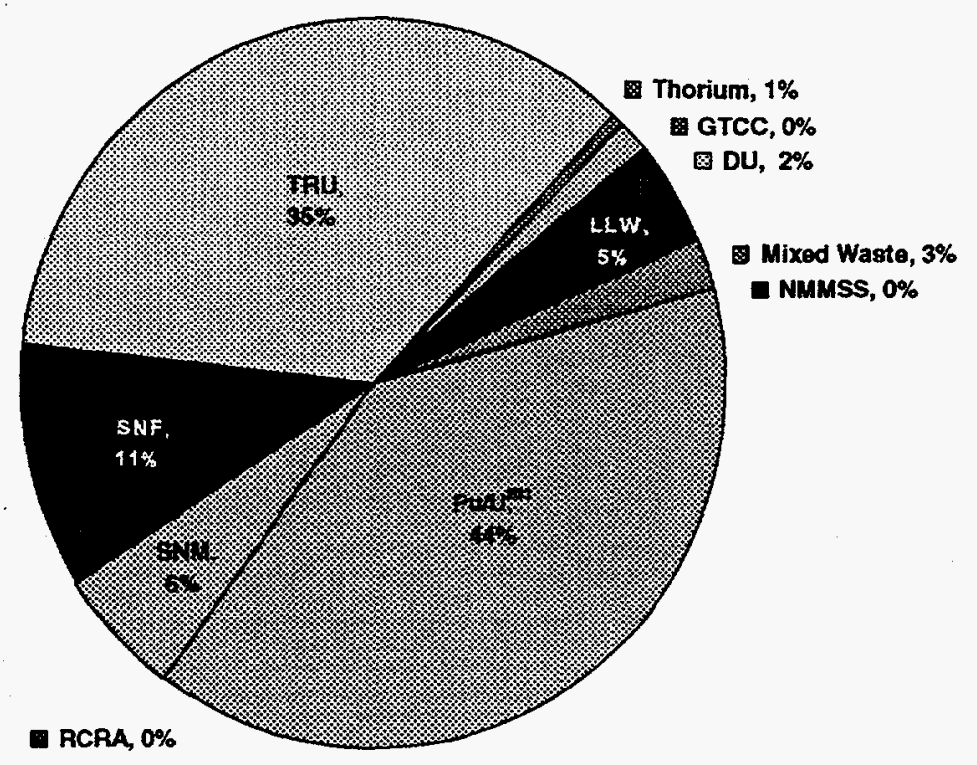

Fig. 5.5. Disposition of CEM by Chart 3-defined form (percentage based on number of items).

ORNL/DWG 96-7231

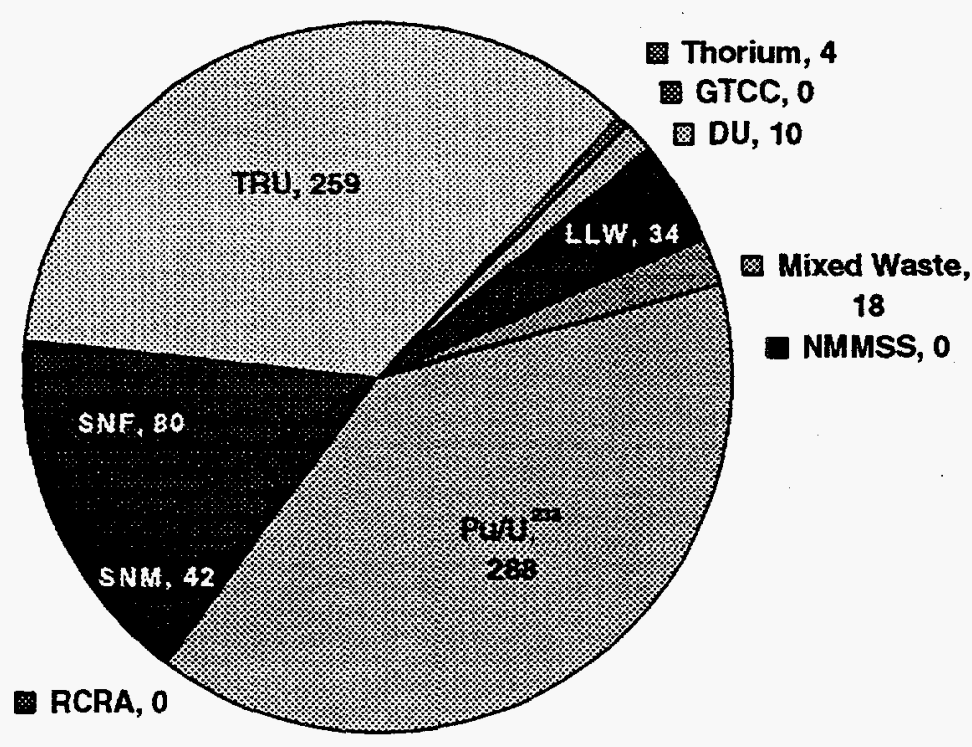

Fig. 5.6. Disposition of CEM by Chart 3-defined form (number of items). 


\subsection{DISPOSITION OF CEM TO OFF-SITE FACILITIES (CHART 7)}

Figures 5.7 and 5.8 present the disposition details for CEM to off-site facilities. It was assumed that any CEM not meeting the disposal PALs for the ORR could be disposed at other sites if the material meets the PALs of those sites. Most of the materials (88\%) that cannot meet the ORR PALs meet the PALs of either the NTS or the HCWF. These amounts acceptable to NTS and

ORNL/DWG 96-7232

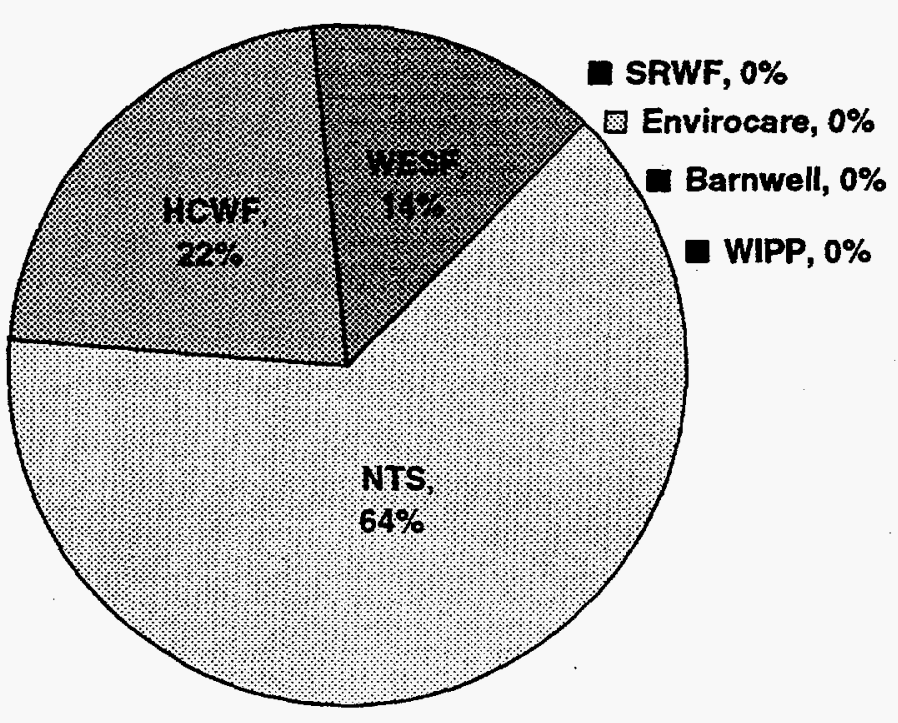

Fig. 5.7. Disposition of CEM by Chart 7 -off-site facilities (percentage based on number of items). 


\section{ORNL/DWG 96-7233}

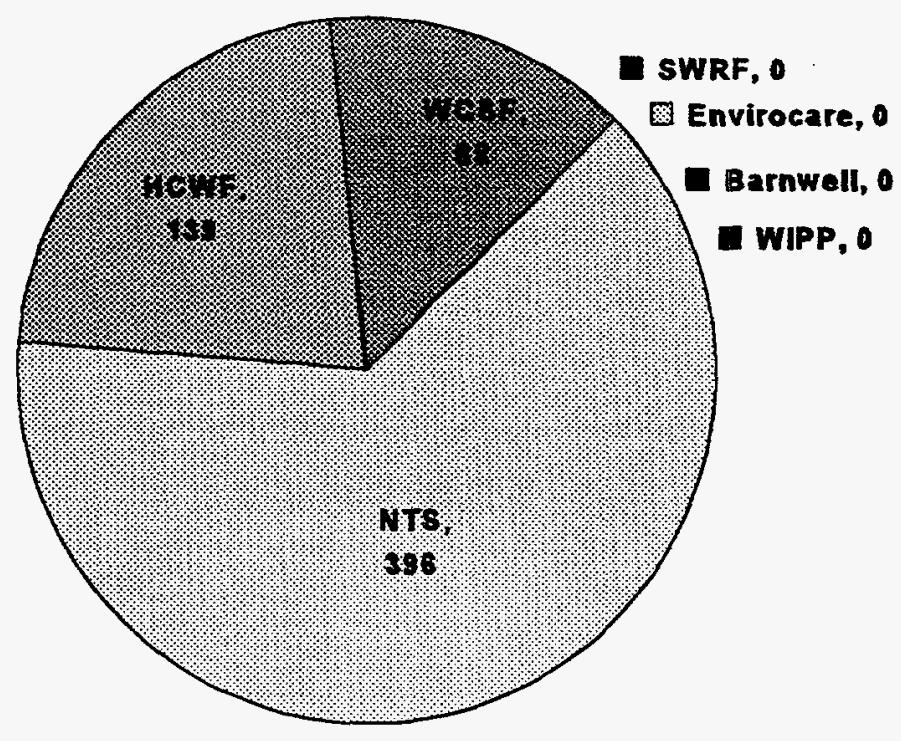

of items).

Fig. 5.8. Disposition of CEM by Chart 7 -off-site facilities (number

HCWF may change, depending on preferences established by DOE, by cost, or by experience. Virtually all the material that has been generally characterized and is to be disposed of can be sent to off-site disposal facilities. Since HCWF and NTS are used preferentially, it was necessary to consider only one other facility, WESF. Since the WESF has been designated as a storage facility for cesium and strontium, most of those materials exceeding the ORR PALS were assigned to the WESF.

It is not possible at this stage of the analysis to be precise about the amount of CEM that will become SCW. Further disposition-path analysis and more data are required to make that determination. However, it is anticipated that much of the uncharacterized category of CEM will be SCW based on its known characteristics. Also, it is likely that some portion of the CEM currently dispositioned for either reuse, handling by an existing program, or disposal, whether onsite or off-site, will be found unsuitable for the indicated pathway. Reuse materials, for example, may not be accepted for logistical or programmatic reasons. Acceptance criteria may change, or particular CEM items may be unable to meet all WAC or shipping requirements. Thus, the amount of SCW based on the number of items inventoried will likely be significant, ranging from 5 to $20 \%$. 


\subsection{ESTIMATES OF VOLUME, WEIGHT, AND RADIOACTIVITY}

A parallel estimate of quantities such as volume, weight, and radioactivity, consistent with the breakdown for all of the items, has not been undertaken. Such an estimate could be made to further define the pathways, provide validation of the disposition made to programs, and eliminate some future concerns. A recent estimate of the volume of CEM was made independently of this analysis of disposition. That estimate is given in Appendix D and includes most of the materials mentioned in this report. 


\section{RECOMMENDATIONS ON A PATH-FORWARD STRATEGY FOR SCW}

Because the continued accumulation of significant quantities of waste and materials with no identified means of disposition represents a vulnerability for DOE, our central goal has been the development of a path forward for this waste, especially that which becomes SCW. In addition to the need for waste management organizations (WMOs) to satisfy their own requirements, these organizations have a commitment to the regulators of the State of Tennessee to address the need for additional waste-storage capacity for SCW. In this section, a strategy is recommended for the successful management of SCW in the present context and some of its impacts are considered.

In Sect. 4, estimates are presented of waste inventories and projections of CEM that could, unless managed properly, become SCW. In Sect. 3 were shown the paths that should be considered for disposition of CEM. In Chapter 5 , it was demonstrated that most of the CEM can be dispositioned in various ways to minimize the amount that will be $\mathrm{SCW}$. Therefore the recommendations herein are based on the premise that disposition for much of the CEM can be found in existing facilities, both off-site and on-site, or to other programs which are funded to manage the CEM as surplus materials or wastes.

\subsection{RECOMMENDATIONS FOR MANAGEMENT OF SCW}

It is recommended that DOE take a proactive management strategy for resolving the SCW issue. The strategy must involve implementation of new policies and methodologies for dealing with CEM and, ultimately, SCW. The various policies recommended and their essential additional considerations are discussed in the following.

\subsubsection{Recommendations Concerning the Means of Disposition of CEM}

The recommended strategy for management of SCW involves implementation of the following policies for the disposition of CEM:

- Require that the customer and their WMO plan and use the best available alternative for each type or piece of equipment or material item that could become SCW.

- Maximize disposition of CEM to existing programs that are funded to manage particular defined materials or wastes.

- Maximize disposition of CEM by recycling and reusing materials.

- Maximize disposition of CEM by disposal in on-site facilities designed to handle the materials, when recycle and reuse are not feasible alternatives. 
- Maximize disposition of CEM by disposal or storage in off-site facilities designed to handle the materials, when recycle, reuse, and on-site disposal are not feasible alternatives.

- Maximize use of existing facilities for storing materials that cannot be dispositioned by the previous means; and

- Use new, dry storage casks or vaults, as necessary, and store on an existing pad at the ORR.

\subsubsection{Use of Existing ORR Facilities}

A question arises at this point as to whether the CEM that will become SCW can be stored at existing storage facilities at the ORR until a disposition path is available. It would appear that existing space will accommodate a significant part of the remaining SCW. A policy must be implemented for the efficient use of the following existing facilities:

- the remote-handled (RH) TRU waste bunker which can be used for mixed waste;

- the relined wells of Building 7827 that are being provided through the SNF Program; and

- the storage pads in SWSA 6, which can be used for storage of large, above-the-ground drystorage casks or vaults for very large CEM that cannot be dispositioned elsewhere.

\subsubsection{Recommendations for DOE on the Implementation of Policy on Management of SCW}

The following policies must be implemented by either DOE or the site contractor. These policies are required to commence proactive management of CEM that will minimize SCW generation where possible and disposition any SCW that is generated.

- Policy should mandate that the disposition path for all CEM must be determined in cooperation with the site's WMO using the disposition logic system (discussed later in Sect. 6.2).

- Policy should prohibit acceptance of waste by the WMO until such waste has been dispositioned and accepted in the logical system by which the WMO manages the wastes.

- Policy should be implemented through discussions with and acceptance by the responsible managers for CEM.

- Policy should make information readily available on the assistance, both technical and financial, that can be provided by the WMO for the disposition of SCW. 


\subsubsection{Recommended Actions to Manage CEM and SCW}

Several actions that are required for the implementation of the policies recommended above are readily apparent. These actions are listed below in order of priority.

1. Develop and immediately implement a policy for the proper management of CEM.

2. Develop a support system in the WMOs to assist the generators and holders of CEM inventory in determining the best path for disposition of CEM.

3. Initiate pilot processes to test the transfer of CEM (wastes) through various paths to determine the viability, methods, schedules, and costs associated with CEM transfers.

4. Initiate an activity to identify and catalogue CEM at the ORNL, $\mathrm{K}-25$, and $\mathrm{Y}-12$ sites.

5. Collect and analyze information on the costs associated with alternative disposition paths.

6. Continue to collect information on uncharacterized wastes and refine disposition paths.

7. Establish a SCW program to proactively implement these recommendations.

\subsubsection{Consequences of Not Implementing Proactive Management of CEM}

Failure to implement proactive management and most of the support policies will result in unacceptable consequences. These consequences, which are avoidable, include the following:

- receipt of waste from operating organizations and programs in a condition that is not acceptable in the long-term for disposal at the ORR, thus increasing vulnerability concerns;

- receipt of materials as waste that could have been reused or recycled and that need not have been declared as waste;

- $\quad$ receipt of wastes that are not packaged properly for transfer to off-site facilities;

- receipt of wastes with inadequate information for disposition to off-site facilities; and

- increased life-cycle costs for the WMOs and, in all likelihood, the DOE complex as a whole.

\subsection{STRATEGY FOR MANAGEMENT OF CEM}

The strategy for management of CEM consists of four elements (Fig. 6.1). Essentially, the strategy entails (1) application of the logical system discussed earlier in this report, (2) support to CEM holders in interpreting the logical system, (2) acceptance by the WMOs of the results 


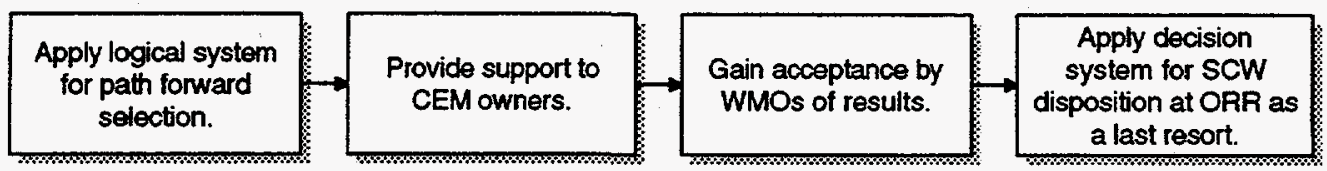

Fig. 6.1. Overview of recommended strategy for CEM management.

from the logical system, and (4) application of a decision system for disposition of SCW at ORNL after all other possibilities have been foreclosed.

\subsubsection{Application of Overall Logic and Decision System}

It is recommended that the operating organizations which are holding CEM that requires disposition use the set of charts given in Sect. 3 (Charts 1-9 in Figs. 3.1-3.9). CEM holders should use these charts to determine the alternatives available to them for their particular CEM items. This practice will enable CEM holders to begin developing an approved path for their CEM. The CEM holder's WMO should have the right to concur or not concur with the alternative(s) selected. It should be noted that, while these charts provide for the disposition of CEM through all alternatives, they do not include a solution for the storage of CEM and SCW in ORR facilities as a last resort. Storage at the ORR is discussed in Sect. 6.2.3.

\subsubsection{Waste Management Functions to Support Strategy}

Several staffed functions and other specific items are needed to ensure that a proactive management strategy can be realized. These requirements must be provided by the WMOs Lockheed Martin Energy Systems, Inc. (LMES) and Lockheed Martin Energy Research Corp. (LMER) with support from DOE-ORO. Some of the functions needed can be provided through the actions listed below.

- Provide assistance in interpreting and applying the decision system for CEM waste management to determine the best disposition alternative for CEM, given constraints of time, funds, and availability of paths.

- Facilitate the various paths for disposition. This should include the issuance of a handbook on how to pursue each disposition path.

- $\quad$ Provide cost estimates and other data for alternative disposition paths. 
- Provide WAC and other material relevant to disposition path selection and implementation.

- Provide design, procurement, and cost information on dry casks and storage vaults.

- Provide monetary assistance to facilitate the shipment of wastes to off-site facilities or to package them for shipment at some future date.

- Provide coordination of shipping and arrangements for off-site disposition.

If adequate funds are not available from WMO budgets to provide the required assistance, some of the support functions indicated could be provided through other means. For example, certain support requests, such as the one indicated in the last bullet above, would be at the waste holder's expense.

\subsubsection{Decision System for ORNL SCW}

As a final resort, some of the CEM will become SCW that must be stored at ORNL. The decision tree involved in identifying a disposition for such SCW is presented in Fig. 6.2. The first part of the tree requires that a final place for disposal of the SCW be identified and that the SCW be packaged in a manner that is acceptable for that location. If it is possible to ship the SCW off-site in the near future, the SCW need not be sent to the ORR waste storage facilities. If the holder can store the SCW as packaged without seriously impairing operations, then storage should be provided at the owner's facility. Finally, after consideration of all of the above, and providing that the SCW meets packaging requirements, options for storage at existing WMO facilities are to be examined. WMO storage options include bunkers, wells, and modular storage containers, (e.g., such as dry casks or vaults). The storage choices identified using the decision analysis logic of Fig. 6.2 should be subject to approval by the WMO.

\subsection{IMPACT OF STRATEGY ON CURRENT PROGRAM AND PLANS}

The recommended strategy would have a significant impact on current programs and plans. Specifically, there would be a major redirection regarding plans for the Class III-IV facility, with attendant National Environmental Protection Act of 1969 (NEPA) ${ }^{*}$ requirements and significant changes in cost allocations. Approval of the recommended path forward, including the use of existing facilities as described in Sect. 6.2, would obviate the need for the Class III-IV Storage Facility.

*The National Environmental Protection Act of 1969 (NEPA), P.L. No. 91-190, 42 USC 4321-4346, as amended by P.L. No. 95-52 and P.L. No. 94-83. 


\subsubsection{Class III-IV Facility}

The current waste management plan calls for two projects to develop additional waste management capacity in SWSA 7. These projects comprise the proposed Class III-IV facility. The Class III-IV below-grade storage project would provide new storage capacity for highspecific-activity LLW. The above-grade storage project would provide new storage capacity for LLW with less activity.

The Class III-IV below-grade storage facility, if approved as proposed, would be funded incrementally using general plant project (GPP) funding and would consist of three phases, as follows:

- Phase I, including excavation, site civil engineering, and one module of eight subgrade storage wells;

- Phase II, consisting of two additional modules which would add a total of 16 subgrade storage wells;

- Phase III, consisting of future module additions which, as projected, would occur at a rate of one module about every 2 years.

Although the design of the Class III-IV facilities is essentially complete, specific design criteria have not yet been prepared. The functional requirements have been prepared and have been through one revision. The proposed wells are double-confinement wells with a steel lined concrete shell and a somewhat removable steel inner sleeve. The term "somewhat removable" is used here because, while this is not an actual overpack design, it is feasible that the waste could eventually be retrieved from the sleeve. The sleeve could then be removed as part of the D\&D activities.

In many respects, the design of the Class III-IV below-grade facility resembles those of the storage wells at Building 7827 at ORNL. The wells would support waste containers with diameters up to that of a 55-gal drum and lengths up to $15 \mathrm{ft}$. The waste containers would have lanyard- and bail-retrievability features. The design is based on high-specific-activity SCW reported previously for ORNL. ${ }^{4}$

Under the recommended CEM management strategy, the option of last resort is to store the CEM at existing facilities after it is packaged. The program would not allow storage on an interim basis, followed by retrieval; characterization; packaging; and, finally, shipment off-site. Contingency storage capacity is available, should the need arise to immediately clear CEM from an ORNL site. The SNF program to clear approximately 20 relined wells in Building 7827 will provide storage capacity, similar to that for the Class III-IV below-grade storage facility, which can be used for buffer storage of SCW waste containers. Contingency storage capacity for larger objects can be found in Buildings 7826 and 7834 at SWSA $5 \mathrm{~N}$. There is also contingency storage 


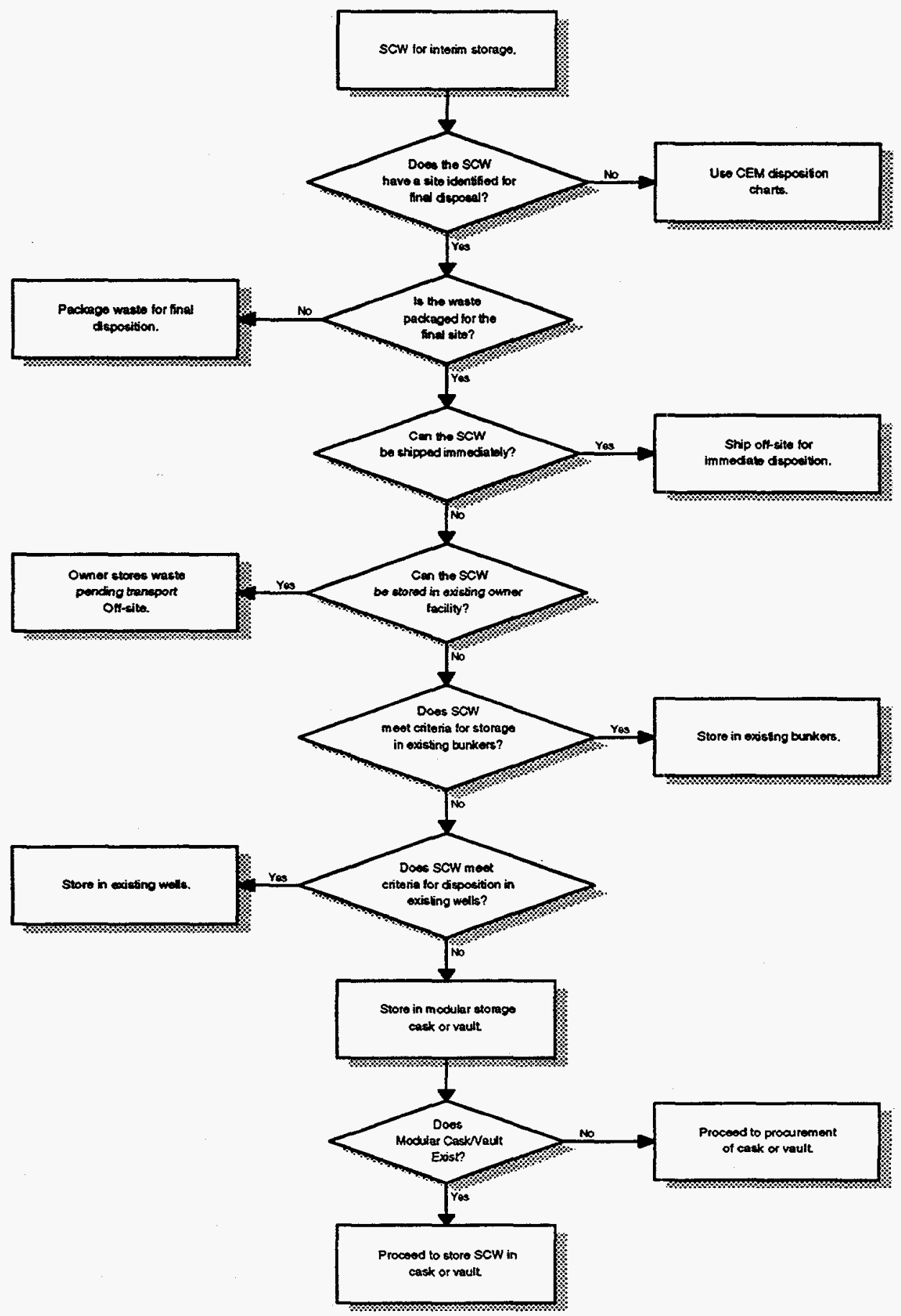

Fig. 6.2. Decision logic for selecting interim storage at the ORR. 
capacity for larger, shielded-cask types of storage containers or commercial dry-storage casks. Above-ground storage capacity is available at the pads at SWSA 6 for CEM which do not fit the category of mixed waste. Mixed waste must be stored in the new RH TRU bunker.

Hence, the recommended strategy represents a simpler, more economical approach than is currently practiced and which more effectively dispositions CEM that might otherwise become SCW. However, this change in strategy could have NEPA implications, and the impact on cost must also be examined.

\subsubsection{NEPA Impact-Revision of the Environmental Assessment}

The recommended path forward would eliminate the need for the planned Class III-IV facility, with probable cost savings and improvements in efficiency. Under NEPA, the impact on environmental protection must also be considered. Other regulations, such as RCRA, must be considered as well.

The environmental assessment (EA) for the construction of the Class III-IV facility ${ }^{6}$ is impacted if the recommended strategy is approved. Revised documentation associated with transfer of highspecific activity SCW from ORNL may be needed to satisfy NEPA. It is not known at this time whether another EA would be required or whether a categorical exclusion would be applicable. Shielded radioisotope transfers of the type proposed are made routinely at ORNL. Hence, if an EA is required, a finding of no significant impact (FONSI) is the anticipated result. A more detailed evaluation of the NEPA requirements based on the recommended SCW path forward is now needed.

There are RCRA permitting requirements that must also be considered. The RCRA permit for the Class III-IV below-grade storage would allow storage of SCW from which lead or other hazardous materials could not be easily separated. Under the recommended path forward, such mixed SCW would make use of the new RH TRU bunker for temporary storage. The new plan may require the concurrence of the State of Tennessee to use the RH TRU bunker for SCW containing hazardous materials under the current permit for ORNL.

\subsection{COST IMPACTS OF RECOMMENDED STRATEGY}

A detailed evaluation of the costs associated with the recommended strategy has not yet been made. However, some cost impacts are evident from the Class III-IV proposal. The use of existing wells, bunkers, and pads for the management of SCW will eliminate the need for the Class III-IV construction project, resulting in immediate cost savings of more than $\$ 2$ million for the basic facilities. The cost to package SCW-type material for off-site transfer is about the same as the cost to package for interim storage. Therefore, the cost for storage containers (if existing facilities are used) would be about equivalent to that for the Class III-IV project scenario. 
Early preparation for off-site transfers or other disposition would lead to earlier expenditures of funds than would be expected under past practices. Because transfers would occur sooner, some costs for the existing-facility scenario would also occur sooner than some costs in the Class III-IVfacility scenario. In the long run, however, direct packaging for the final location will be more cost effective than packaging for interim storage and then repackaging for final disposition.

Steps can be taken to achieve further cost effectiveness: (1) the standardization of containers, (2) the pooling of requirements to reduce procurement costs, and (3) the use of recycled materials when they are available in proper form. A cost-analysis study of SCW management could be performed to ensure that the most efficient and cost-effective methods are used, but it would be difficult to do. It is clear that it is considerably more expensive to package SCW for storage at ORNL, move it, examine it, verify it, repackage it to meet the WAC for off-site disposal, and then ship it off-site as compared to packaging the SCW for off-site disposition at the outset. It is of higher priority to spend the first available funding toward the disposition of CEM directly, rather than on studying and estimating the cost of various alternatives. It may be important, however, for the SCW program to track the costs and successes of alternative disposition pathways to help plan for future choices. 


\section{SCW ACTIVITIES FOR FISCAL YEAR (FY) 1997 AND OUT YEARS}

The strategy and recommendations presented in Sect. 6 indicate the need for new activities in the near term. Activities that might be undertaken for the balance of FY 1997, and in subsequent years include the establishment of a program for SCW management.

\subsection{SCW PROGRAM}

The SCW Program would have the initial goals of prioritizing existing SCW, proactively working toward its disposition, and implementing the proposed strategy. Some elements of the SCW Program mission are outlined below.

\subsubsection{SCW Policy Implementation}

The SCW Program would work to develop the support system needed for the implementation of SCW proactive management. This would entail promulgation of the new policy and execution of activities to apply the required tools for CEM decision analysis.

\subsubsection{SCW-Generation Forecasting}

The SCW program will have the responsibility for analyzing ORR operations and future programs with regard to SCW generation. The principle goals here will be to determine the amount and types of SCW that could be created and develop plans for its management. The first step will be to carefully catalogue existing CEM at the ORR and, to the greatest extent possible, identify anticipated CEM for the foreseeable future. Next, the three-plant CEM catalogue must be maintained and updated annually.

\subsubsection{Facilitation of CEM Disposition}

An important role of the SCW Program will be to act as the interface with CEM holders and the WMOs to ensure that CEM receives disposition. Two important elements of work for the program will be to further define the paths (via discussion with relevant stakeholders) and to gain the acceptance of responsible managers and oversight personnel. Work is also required to decrease the amount of uncharacterized CEM.

Depending on the objectives of each program or responsible entity, it may be necessary to analyze in more detail the possible disposition paths for the CEM. The analysis might focus, for example, on the life-cycle costs (Sect. 7.3) of disposal alternatives. Where available, such costs can be determined based on prior waste management experiences. However, for disposition paths that are different and untried, it will be important to establish the validity of the disposition option and, at the same time, gather cost data through demonstration or pilot disposition projects (Sect. 7.2). 


\subsection{PILOT DISPOSITION DEMONSTRATIONS}

Because LMES and LMER have an ongoing need to dispose of CEM, it is essential that detailed paths be clarified and demonstrated so that larger-scale disposition can proceed. At least three types of projects might be carried out by the SCW program:

1. Identification and demonstration of transfer to off-site waste management facilities of several key CEM items. The purpose of this effort is to learn how to work with the infrastructure (e.g., Hanford and DOE-Headquarters) to get materials transferred to off-site locations. This experience could then be applied more broadly.

2. Identification and demonstration of off-site transfer of several CEM items now in storage in closed-down processing or laboratory facilities. These would be done to demonstrate a methodology which could be used to accelerate decommissioning of a facility.

3. Retrieval, characterization, and disposition of sources or waste materials that are currently stored in waste management facilities (e.g., at ORNL) and are assumed to be SCW. The purpose would be to prove that many of these items can be dispositioned.

\subsection{DEVELOPMENT OF LIFE-CYCLE MODELS BY DISPOSITION PATH}

Life-cycle modeling for the various paths would provide stakeholders an informed determination of the path of choice. One activity under the SCW Program would be consolidating information related to cost, protocols, procedures, compliance issues, and other matters that are part of the logistics of transfer, storage, and disposal of the CEM. Much of this information would be obtained from the pilot disposition demonstrations discussed earlier.

\subsection{FUTURE WORK}

The next step, following the development of this report, should be to initiate those actions discussed above. The emphasis, as funds are available, should be on the (1) refinement of information and assignment dispositions to CEM now classified as uncharacterized waste, (2) demonstration of transfer of materials and wastes off-site, and (3) development of an agreement among stakeholders and managers on the path forward for the various disposition categories.

Emphasis should then be placed on (1) reducing the generation of potential SCW, (2) transferring CEM to the final or interim sites for disposition, and (3) establishing mechanisms for the generator to facilitate the proper disposition of CEM so that it does not become SCW. 


\section{CONCLUSIONS}

The vulnerability finding identified in the DOE-EM 1996 report $^{1}$ pointed out a need to develop a technical path forward for the disposition of SCW at the ORR. This report addresses that need by providing a logical process for determining disposition options for SCW, examining the current scope and nature of SCW at the ORR, and applying the logic system to the SCW inventory using existing information. As a result, preliminary disposition pathways for $\mathrm{SCW}$ have been identified and a new strategy for SCW management has been developed, with implications for current- and out-year activities.

The logical process developed as part of this work will be a key instrument for expediting CEM disposition and for the elimination of SCW. It will facilitate the early identification of disposition options for CEM and thus enable such materials to be packaged in a manner appropriate for final disposition. However, for its use to be effective, it is important that both CEM holders and WMOs understand and accept the CEM disposition logic.

The preliminary disposition analysis reported herein provides clear indication for a strategy to eliminate legacy SCW and effectively manage CEM on an on-going basis to minimize future SCW generation. Furthermore, the analysis provides the basis for the establishment of a technical path forward to disposition for the SCW identified in this report. Much of the material can now be prepared for handoff to established programs, some can be reused or recycled, while others may now be prepared for off-site disposition. It is also clear that some CEM must undergo further characterization or other processing before final disposition can be achieved. However, the steps necessary to accomplish this are feasible and within the scope of SCW program activities, as discussed in Sect. 7.

Finally, it should be recalled that the information on CEM inventories used in this report is of a preliminary nature. Further actions are needed to provided a more detailed and complete inventory to support the strategy recommended and provide for development and implementation of more specific plans for the disposition of CEM and legacy SCW. 


\section{REFERENCES}

1. U.S. Department of Energy, Final Report: Complex-Wide Review of DOE's Low-Level Waste Management ES\&H Vulnerabilities, Site-Specific Assessment Reports, Volume III, DOE/EM-0280, U.S. Department of Energy, Office of Environmental Management, Washington, D.C., May 1996.

2. Idaho National Engineering Laboratory, Departmemt of Energy Special Case Radioactive Waste Imventory and Characterization Data Report, DOE/LLW-96, Radioactive Waste Technical Support Program, Idaho National Engineering Laboratory, Idaho Falls, Idaho, May 1990 (draft).

3. J. R. Forgy, Jr., Special Case Waste Located at Oak Ridge National Laboratory Facilities-Survey Report, Waste Management and Remedial Action Division (WMRAD), 456-831-3, Lockheed Martin Energy Systems, Inc., Oak Ridge, Tennessee, September 1995.

4. U.S. Department of Energy, Imegrated Data Base Report-1994: U. S. Spent Nuclear Fuel and Radioactive Waste Invemtories, Projections, and Characteristics, DOE/RW-0006, Rev. 11, Oak Ridge National Laboratory, Oak Ridge, Tennessee, September 1995.

5. D. S. Eaker, et al., Materials in Inventory, ES/M-9/V1-9, 9 Vols., Lockheed Martin Energy Systems, Inc., Oak Ridge, Tennessee, August 1995.

6. U.S. Department of Energy, Draft Environmental Assessment: Construction and Operation of Class III-IV Solid LLW Storage Facilities at SWSA 7, DOE/EA-1043, U.S. Department of Energy, Oak Ridge Operations Office, Oak Ridge, Tennessee, November 1995. 
Appendix A

\section{DEFINITION OF VARIOUS MATERIALS IN PROCESS AND WASTE FORMS} DEFINED BY LAW OR PRACTICE 


\section{DEFINITION OF VARIOUS MATERIALS IN PROCESS AND WASTE FORMS DEFINED BY LAW OR PRACTICE}

Depleted Uranium (DU). DU is uranium in which the percentage by weight of the isotope ${ }^{235} U$ in the total uranium present is less than that occurring in natural (normal) uranium. The natural abundance of ${ }^{235} \mathrm{U}$ in uranium is $0.711 \mathrm{wt} \%$.

Special Nuclear Materials-Natural and Enriched Uranium. Natural and enriched uranium includes all forms of natural and enriched uranium. In natural uranium the abundance of ${ }^{235} U$ is $0.711 \%$. Enriched uranium has a weight percent of ${ }^{235} \mathrm{U}$ greater than that of natural uranium, including both low enriched (LEU) and highly enriched uranium (HEU). HEU is uranium containing more than $20 \mathrm{wt} \%{ }^{235} \mathrm{U}$. LEU is enriched uranium containing up to $20 \mathrm{wt} \%{ }^{235} \mathrm{U}$.

Plutonium and ${ }^{233} \mathrm{U}$ Program Materials. This category includes ${ }^{239-241} \mathrm{Pu},{ }^{238} \mathrm{Pu}$ greater than $10 \%$, ${ }^{242} \mathrm{Pu},{ }^{233} \mathrm{U}$ greater than $20 \%$ by weight, and ${ }^{232} \mathrm{U}$.

Spent Nuclear Fuel (SNF). SNF is fuel that has been withdrawn from a nuclear reactor following irradiation and the constituent elements of which have not been separated or processed. SNF also includes irradiated target material, blanket subassemblies, pieces of fuel, and fuel debris. Fuel that has been lightly irradiated and can be contact handled is included in this definition for DOE's SNF Program.

Transuranic (TRU) Waste. Without regard to source or form, waste that is contaminated with alpha-emitting transuranium radionuclides with an atomic number $>92$ and with half-lives greater than 20 years and concentrations greater than $100 \mathrm{nCi}$ alpha/g of waste at the time of assay. In addition, radium sources and ${ }^{233} \mathrm{U}$ in concentrations greater than $100 \mathrm{nCi} / \mathrm{g}$ of the waste matrix are managed as TRU waste.

Mixed Waste. Waste containing both radioactive and hazardous components as defined by the Atomic Energy Act (AEA) and the Resource Conservation and Recovery Act (RCRA), respectively. (DOE Order 5820.2A, Attachment 2).

Hazardous (RCRA) Waste. Those solid wastes designated by 40 CFR Part 261, and regulated as hazardous waste or mixed waste by the EPA (WAC 173-303-040) (40 CFR Part 260.10) (10 CFR Part 61.2) (DOE Order 5820.2A, Attachment 2) (49 CFR Part 171.8).

Low-Level Radioactive Waste (LLW). Waste that contains radioactivity and is not classified as high-level waste (HLW), transuranic (TRU) waste, SNF or 11E(2) byproduct material as defined by DOE Order 5820.2A. A test specimen of fissionable material irradiated for research and development only and not for the production of power or plutonium may be classified as LLW provided the concentration of TRU materials is less than $100 \mathrm{nCi} / \mathrm{g}$ (DOE Order 5820.2A, Attachment 2). 
Greater Than Class C Waste (GTTC). GTCC waste is high specific activity LLW accepted from the NRC by DOE, with concentrations that exceed the Class Climits, as defined by 10 CFR Part 61.2 (Table 4.1). This nomenclature is sometimes used to refer to DOE wastes that are similar to GTCC wastes. 
Appendix B

WASTE ACCEPTANCE CRITERIA (WACs) FOR VARIOUS DISPOSAL FACILITIES THROUGHOUT THE DOE COMPLEX 


\section{WASTE ACCEPTANCE CRITERIA (WACS) FOR VARIOUS DISPOSAL FACILITIES THROUGHOUT THE DOE COMPLEX}

Acceptance criteria for several waste disposal facilities across the DOE Complex are presented here.

\section{B. 1 THE INTERIM WASTE MANAGEMENT FACILITY (IWMF) AT THE OAK RIDGE RESERVATION (ORR)}

Table B.1 gives the limits for LLW waste disposal at the IWMF, the only LLW disposal facility on the Oak Ridge Reservation (ORR). ${ }^{1}$

\section{B.2 THE HANFORD SITE}

Tables B.2 and B.3 give the limits for LLW disposal at the Hanford site. ${ }^{2}$ A radionuclide characterization document must be prepared if process knowledge is used to determine the radionuclide content of their waste. This document includes the process knowledge, analyses, calculations, and scaling factors used to determine the radionuclide content of each waste stream. Once radionuclide compositions are known, the limits of Table B. 2 are used in a sum of the fractions calculation to determine the Hanford radionuclide disposal category for each container. Mobile radionuclides are indicated in Table B.3. Wastes with mobile radionuclides that exceed the reporting limits indicated in Table B.3 may require stabilization.

\section{B.3 THE NEVADA TEST SITE (NTS)}

The NTS acceptance limits for radionuclides in LLW are being developed and therefore have not yet been released. Table B.4 gives the guidance as to what the limits for LLW disposal at the NTS may look like. While these are not official WACs, they were used as a basis for the path forward analysis in this report.

\section{B.4 THE WASTE ISOLATION PILOT PLAN (WIPP)}

Acceptance limits for $\mathrm{CH}$ waste containing TRU radionuclides are given in Tables B.5-B.8:

\section{B.5 REFERENCES}

1. Energy Systems Waste Management Organization, Waste Acceptance Criteria for the Oak Ridge Reservation, ES/WM-10, Lockheed Martin Energy Systems, Oak Ridge, Tennessee, July 1994.

2. Hanford Site Solid Waste Acceptance Criteria, WHC-EP-0063-4, Westinghouse Hanford Company, Richland, Washington, November 1993 (revised May 1996). 
Table B.1 PALs for the ORNL IWMF (ref. 1)

\begin{tabular}{|c|c|c|c|c|c|}
\hline Isotope & $\begin{array}{c}\text { Half-life } \\
\text { (years) }\end{array}$ & $\begin{array}{l}\text { Concentration } \\
\text { Limit }\left(\mathrm{Ci} / \mathrm{ft}^{3}\right)^{a}\end{array}$ & Isotope & $\begin{array}{l}\text { Half-life } \\
\text { (years) }\end{array}$ & $\begin{array}{l}\text { Concentration } \\
\text { Limit }\left(\mathrm{Ci} / \mathrm{ft}^{3}\right)^{a}\end{array}$ \\
\hline${ }^{3} \mathrm{H}$ & $1.22 \mathrm{E}+01$ & $5.319 E+00$ & ${ }^{23 !} \mathrm{Pa}$ & $3.25 \mathrm{E}+04$ & $1.212 \mathrm{E}-07$ \\
\hline${ }^{14} \mathrm{C}$ & $5.73 E+03$ & $4.894 E-04$ & ${ }^{232} \mathrm{Th}$ & $1.41 E+10$ & $1.646 E-06$ \\
\hline${ }^{26} \mathrm{Al}$ & $7.20 \mathrm{E}+05$ & $1.445 \mathrm{E}-06$ & ${ }^{232} \mathrm{U}$ & $7.20 \mathrm{E}+01$ & $4.706 E-06$ \\
\hline${ }^{36} \mathrm{Ci}$ & $3.01 \mathrm{E}+05$ & $5.903 E-06$ & ${ }^{233} \mathrm{U}$ & $1.60 \mathrm{E}+04$ & $6.520 \mathrm{E}-04$ \\
\hline${ }^{40} \mathrm{~K}$ & $1.28 \mathrm{E}+09$ & $2.082 \mathrm{E}-05$ & ${ }^{234} \mathrm{U}$ & $2.45 \mathrm{E}+05$ & $6.441 E-04$ \\
\hline${ }^{60} \mathrm{Co}$ & $5.27 E+00$ & $1.251 \mathrm{E}+01$ & ${ }^{235} \mathrm{U}$ & $7.04 \mathrm{E}+08$ & $3.726 E-05$ \\
\hline${ }^{63} \mathrm{Ni}$ & $1.00 \mathrm{E}+02$ & $3.128 \mathrm{E}-01$ & ${ }^{236} U$ & $2.42 \mathrm{E}+07$ & $7.079 E-04$ \\
\hline${ }^{85} \mathrm{Kr}$ & $1.07 \mathrm{E}+01$ & $2.185 E+01$ & ${ }^{237} \mathrm{~Np}$ & $2.10 \mathrm{E}+06$ & $1.221 \mathrm{E}-05$ \\
\hline${ }^{90} \mathrm{Sr}$ & $2.86 \mathrm{E}+01$ & $4.436 E-03$ & ${ }^{238} \mathrm{Pu}$ & $8.78 \mathrm{E}+01$ & $2.226 \mathrm{E}-03$ \\
\hline${ }^{99} \mathrm{Tc}$ & $2.13 \mathrm{E}+05$ & $6.442 E-04$ & ${ }^{238} \mathrm{U}$ & $4.47 E+09$ & $1.770 \mathrm{E}-04$ \\
\hline${ }^{129} \mathbf{I}$ & $1.57 E+07$ & $1.204 E-07$ & ${ }^{239} \mathrm{Pu}$ & $2.41 E+04$ & $1.785 E-04$ \\
\hline${ }^{137} \mathrm{Cs}$ & $3.02 \mathrm{E}+01$ & $2.200 E-03$ & ${ }^{240} \mathrm{Pu}$ & $6.57 E+03$ & $1.827 E-04$ \\
\hline${ }^{151} \mathrm{Sm}$ & $9.00 \mathrm{E}+01$ & $4.755 E-01$ & ${ }^{241} \mathrm{Am}$ & $4.32 \mathrm{E}+02$ & $2.045 E-04$ \\
\hline${ }^{152} \mathrm{Eu}$ & $1.36 \mathrm{E}+01$ & $1.180 E-02$ & ${ }^{242} \mathrm{Pu}$ & $3.76 \mathrm{E}+05$ & $1.864 E-04$ \\
\hline${ }^{154} \mathrm{Eu}$ & $8.80 E+00$ & $1.693 E-01$ & ${ }^{243} \mathrm{Am}$ & $7.38 E+03$ & $2.694 E-05$ \\
\hline${ }^{156} \mathrm{Eu}$ & $4.96 E+00$ & $3.183 E+05$ & ${ }^{243} \mathrm{Cm}$ & $2.85 \mathrm{E}+01$ & $5.034 \mathrm{E}-02$ \\
\hline${ }^{207} \mathrm{Bi}$ & $3.22 \mathrm{E}+01$ & $3.197 E-02$ & ${ }^{244} \mathrm{Cm}$ & $7.81 \mathrm{E}+01$ & $2.500 \mathrm{E}-01$ \\
\hline${ }^{209} \mathrm{Po}$ & $1.03 \mathrm{E}+02$ & $9-077 E^{-} 07$ & ${ }^{244} \mathrm{Pu}$ & $8.20 \mathrm{E}+07$ & $1.204 \mathrm{E}-07$ \\
\hline${ }^{210} \mathrm{~Pb}$ & $2.23 \mathrm{E}+01$ & $5.308 E-03$ & ${ }^{248} \mathrm{Cm}$ & $3.40 \mathrm{E}+05$ & $1.205 E-07$ \\
\hline${ }^{226} \mathrm{Ra}$ & $1.60 E+03$ & $2.372 \mathrm{E}-06$ & ${ }^{249} \mathrm{Bk}$ & & \\
\hline${ }^{228} \mathrm{Ra}$ & $5.75 E+00$ & $3.468 \mathrm{E}+01$ & ${ }^{249} \mathrm{Cf}$ & $3.51 E+02$ & $2.247 E-05$ \\
\hline${ }^{229} \mathrm{Th}$ & $7.34 \mathrm{E}+03$ & $1.400 \mathrm{E}-05$ & ${ }^{250} \mathrm{Cf}$ & $1.31 \mathrm{E}+01$ & $1.089 \mathrm{E}+00$ \\
\hline${ }^{230} \mathrm{Th}$ & $8.00 E+04$ & $6.452 E-04$ & & & \\
\hline
\end{tabular}

a The concentration limits are from WM-SWO-502. Concentration limits are derived by dividing the performance assessment limits, in curies, by the volume of storage space available in the on-site disposal facility, in cubic feet. In actual practice, the concentration limits are specified in Ci per storage vault ( 96.4 cubic $f t$ volume). 
Table B.2 Category 1 and 3 activity limits for disposal at the Hanford Site (ref 2)

\begin{tabular}{|c|c|c|c|c|c|}
\hline \multirow{3}{*}{ Nuclide } & \multicolumn{5}{|c|}{ Activity Limits $\left(\mathrm{Ci} / \mathrm{m}^{3}\right)$} \\
\hline & \multicolumn{2}{|c|}{ Waste limit } & \multirow{2}{*}{ Class $\mathrm{C}^{a}$} & \multicolumn{2}{|c|}{ Category 3} \\
\hline & Category 1 & Category 3 & & $\begin{array}{l}\text { Noncombustible waste } \\
\text { limit }\end{array}$ & $\begin{array}{l}\text { Combustible } \\
\text { waste limit }\end{array}$ \\
\hline${ }^{3} \mathrm{H}^{\mathrm{f}}$ & $9.9 E+04$ & c & c & $4.0 \mathrm{E}+07$ & $5.0 \mathrm{E}+02$ \\
\hline${ }^{10} \mathrm{Be}$ & $1.1 \mathrm{E}+00$ & $2.4 E+02$ & & $1.0 \mathrm{E}+04$ & $2.5 \mathrm{E}+02$ \\
\hline${ }^{14} \mathrm{C}$ & $9.1 \mathrm{E}-02$ & $2.1 \mathrm{E}+01$ & $8.0 \mathrm{E}+00$ & $1.8 \mathrm{E}+06$ & $4.4 \mathrm{E}+04$ \\
\hline${ }^{14} \mathrm{C}^{\mathrm{a}}$ & $9.1 E-01$ & $2.1 E+02$ & $8.0 \mathrm{E}+01$ & $1.8 \mathrm{E}+06$ & $4.4 \mathrm{E}+04$ \\
\hline${ }^{36} \mathrm{Cl}$ & $6.4 E-05$ & $1.4 E-01$ & & $1.7 \mathrm{E}+05$ & $4.2 \mathrm{E}+03$ \\
\hline${ }^{40} \mathrm{~K}$ & $1.8 E-03$ & $3.8 E-01$ & & $3.0 \mathrm{E}+05$ & $7.5 E+03$ \\
\hline${ }^{59} \mathrm{Ni}$ & $3.9 E+00$ & $8.5 E+02$ & & $2.9 E+06$ & $7.1 \mathrm{E}+04$ \\
\hline${ }^{59} \mathrm{Ni}^{\mathrm{a}}$ & $3.9 E+01$ & $8.5 E+03$ & $2.2 \mathrm{E}+02$ & $2.9 \mathrm{E}+06$ & $7.1 \mathrm{E}+04$ \\
\hline${ }^{60} \mathrm{Co}$ & $7.5 E+01$ & & & $1.8 \mathrm{E}+04$ & $4.5 \mathrm{E}+02$ \\
\hline${ }^{60} \mathrm{Co}^{\mathrm{af}}$ & $7.5 \mathrm{E}+02$ & & & $1.8 \mathrm{E}+04$ & $4.5 \mathrm{E}+02$ \\
\hline${ }^{63} \mathrm{Ni}$ & $5.9 E+00$ & $2.0 \mathrm{E}+04$ & $7.0 \mathrm{E}+02$ & $1.2 \mathrm{E}+06$ & $3.0 \mathrm{E}+04$ \\
\hline${ }^{63} \mathrm{Ni}^{\mathrm{a}}$ & $5.9 \mathrm{E}+01$ & $2.0 E+05$ & $7.0 \mathrm{E}+03$ & $1.2 \mathrm{E}+06$ & $3.0 \mathrm{E}+04$ \\
\hline${ }^{79} \mathrm{Se}$ & $5.1 E-01$ & $1.1 E+02$ & & $3.9 \mathrm{E}+05$ & $9.7 E+03$ \\
\hline${ }^{90} \mathrm{Sr}$ & $1.6 E-02$ & $5.4 E+04$ & $7.0 \mathrm{E}+03$ & $1.5 \mathrm{E}+04$ & $3.7 E+02$ \\
\hline${ }^{93} \mathrm{Zr}$ & $2.5 E+00$ & $5.4 E+02$ & & $4.6 \mathrm{E}+03$ & $1.2 E+02$ \\
\hline${ }^{93} \mathrm{Mo}$ & $8.7 E-01$ & $2.0 \mathrm{E}+02$ & & $1.3 E+05$ & $3.2 E+03$ \\
\hline${ }^{94} \mathrm{Nb}$ & $2.2 E-04$ & $4.8 E-02$ & & $9.2 \mathrm{E}+03$ & $2.3 E+02$ \\
\hline${ }^{94} \mathrm{Nb}^{\mathrm{a}}$ & $2.2 E-03$ & $4.8 E-01$ & $2.0 \mathrm{E}-01$ & $9.2 \mathrm{E}+03$ & $2.3 E+02$ \\
\hline${ }^{99} \mathrm{Tc}$ & $2.3 E-02$ & $5.0 E+00$ & $3.0 E+00$ & $4.0 \mathrm{E}+05$ & $1.0 \mathrm{E}+04$ \\
\hline${ }^{107} \mathrm{Pd}$ & $1.5 E+01$ & $3.3 E+03$ & & $2.9 E+05$ & $7.1 E+03$ \\
\hline${ }^{113 \mathrm{~m}} \mathrm{Cd}$ & $7.6 E-01$ & & & $1.8 \mathrm{E}+03$ & $4.5 \mathrm{E}+01$ \\
\hline${ }^{121 m} S n$ & $6.7 E-01$ & $2.2 E+04$ & & $3.1 \mathrm{E}+05$ & $7.7 E+03$ \\
\hline${ }^{126} \mathrm{Sn}$ & $1.6 E-04$ & $3.4 E-02$ & & $3.6 \mathrm{E}+04$ & $9.1 \mathrm{E}+02$ \\
\hline${ }^{129} \mathrm{I}$ & $8.5 E-03$ & $1.8 E+00$ & $8.0 E-02$ & $7.1 E+03$ & $8.9 \mathrm{E}-02$ \\
\hline
\end{tabular}

B-3 
Table B.2 Category 1 and 3 activity limits for disposal at the Hanford Site (ref 2) (continued)

\begin{tabular}{|c|c|c|c|c|c|}
\hline \multirow{3}{*}{ Nuclide } & \multicolumn{5}{|c|}{ Activity Limits $\left(\mathrm{Ci} / \mathrm{m}^{3}\right)$} \\
\hline & \multicolumn{2}{|c|}{ Waste limit } & \multirow{2}{*}{ Class $\mathrm{C}^{c}$} & \multicolumn{2}{|c|}{ Category 3} \\
\hline & Category 1 & Category 3 & & $\begin{array}{l}\text { Noncombustible waste } \\
\text { limit }\end{array}$ & $\begin{array}{l}\text { Combustible } \\
\text { waste limit }\end{array}$ \\
\hline${ }^{133} \mathrm{Ba}$ & $7.1 \mathrm{E}-01$ & & & $4.6 \mathrm{E}+05$ & $1.2 \mathrm{E}+04$ \\
\hline${ }^{135} \mathrm{Cs}$ & $1.6 \mathrm{E}-01$ & $3.5 \mathrm{E}+01$ & & $8.0 E+05$ & $2.0 \mathrm{E}+04$ \\
\hline${ }^{137} \mathrm{Cs}$ & $5.5 \mathrm{E}-03$ & $1.2 E+04$ & $4.6 E+03$ & $1.2 \mathrm{E}+05$ & $3.0 \mathrm{E}+03$ \\
\hline${ }^{147} \mathrm{Sm}$ & $1.7 E-02$ & $3.7 E+00$ & & $2.9 \mathrm{E}+01$ & $7.1 \mathrm{E}-01$ \\
\hline${ }^{150} \mathrm{Eu}$ & $1.4 \mathrm{E}-03$ & $6.7 E+02$ & & $1.4 \mathrm{E}+04$ & $3.4 \mathrm{E}+02$ \\
\hline${ }^{151} \mathrm{Sm}$ & $4.6 \mathrm{E}+01$ & $2.1 E+05$ & & $7.1 \mathrm{E}+04$ & $1.8 E+03$ \\
\hline${ }^{152} \mathrm{Eu}$ & $4.8 E-02$ & & & $1.7 E+04$ & $4.3 E+02$ \\
\hline${ }^{152} \mathrm{Gd}$ & $6.4 E-03$ & $1.4 \mathrm{E}+00$ & & $3.6 \mathrm{E}+00$ & $9.1 \mathrm{E}-02$ \\
\hline${ }^{154} \mathrm{Eu}$ & $7.5 E-01$ & & & $1.3 \mathrm{E}+04$ & $3.3 E+02$ \\
\hline${ }^{187} \mathrm{Re}$ & $3.6 E+01$ & $7.8 E+03$ & & $6.3 \mathrm{E}+07$ & $1.6 E+06$ \\
\hline${ }^{209} \mathrm{Po}$ & $9.8 E-03$ & $3.2 \mathrm{E}+01$ & & $3.0 \mathrm{E}+02$ & $7.5 E+00$ \\
\hline${ }^{210} \mathrm{~Pb}$ & $3.7 E-02$ & $2.1 E+06$ & & $1.8 \mathrm{E}+02$ & $4.5 E+00$ \\
\hline${ }^{226} \mathrm{Ra}$ & $1.7 E-04$ & $4.3 E-02$ & & $4 * 4 E+02$ & $1.1 \mathrm{E}+01$ \\
\hline${ }^{227} \mathrm{Ac}$ & $4.2 E-03$ & $3.0 \mathrm{E}+05$ & & $3.1 \mathrm{E}-01$ & $7.7 E-03$ \\
\hline${ }^{228} \mathrm{Ra}$ & $1.7 E+01$ & & & $8.6 E+02$ & $2.1 \mathrm{E}+01$ \\
\hline${ }^{229} \mathrm{Th}$ & $4.4 E-04$ & $9.8 E-02$ & & $7.1 \mathrm{E}-01$ & $1.8 E-02$ \\
\hline${ }^{230} \mathrm{Th}$ & $2.1 E-03$ & $1.5 E-01$ & & $4.6 \mathrm{E}+00$ & $1.2 \mathrm{E}-01$ \\
\hline${ }^{23 !} \mathrm{Pa}$ & $1.4 E-04$ & $3.0 E-02$ & & $1.1 \mathrm{E}+00$ & $2.7 E-02$ \\
\hline${ }^{232} \mathrm{Th}$ & $1.1 E-04$ & $2.3 E-02$ & & $8.6 E-01$ & $2.1 \mathrm{E}-02$ \\
\hline${ }^{232} \mathrm{U}$ & $4.6 \mathrm{E}-04$ & $4.6 E+00$ & & $5.5 \mathrm{E}+00$ & $1.4 \mathrm{E}-01$ \\
\hline${ }^{233} \mathrm{U}^{\mathrm{b}}$ & $7.4 E-03$ & $9.7 E-01$ & & $2.7 \mathrm{E}+01$ & $6.7 E-01$ \\
\hline${ }^{234} \mathrm{U}$ & $8.9 E-03$ & $1.9 E+00$ & & $2.7 E+01$ & $6.8 E-01$ \\
\hline${ }^{235} \mathrm{U}$ & $2.8 \mathrm{E}-03$ & $5.0 \mathrm{E}-01$ & & $2.9 \mathrm{E}+01$ & $7.3 E-01$ \\
\hline${ }^{236} \mathrm{U}$. & $9.5 E-03$ & $2.0 E+00$ & & $2.9 \mathrm{E}+01$ & $7.1 \mathrm{E}-01$ \\
\hline
\end{tabular}

B-4 
Table B.2 Category 1 and 3 activity limits for disposal at the Hanford Site (ref 2) (continued)

\begin{tabular}{|c|c|c|c|c|c|}
\hline \multirow{3}{*}{ Nuclide } & \multicolumn{5}{|c|}{ Activity Limits $\left(\mathrm{Ci} / \mathrm{m}^{3}\right)$} \\
\hline & \multicolumn{2}{|c|}{ Waste limit } & \multirow{2}{*}{ Class $\mathrm{C}^{a}$} & \multicolumn{2}{|c|}{ Category 3} \\
\hline & Category 1 & Category 3 & & $\begin{array}{l}\text { Noncombustible waste } \\
\text { limit }\end{array}$ & $\begin{array}{l}\text { Combustible } \\
\text { waste limit }\end{array}$ \\
\hline${ }^{237} \mathrm{~Np}^{b}$ & $6.8 E-04$ & $1.5 \mathrm{E}-01$ & & $2.6 \mathrm{E}+00$ & $6.4 \mathrm{E}-02$ \\
\hline${ }^{238} \mathrm{U}$ & $5.7 \mathrm{E}-03$ & $1.2 \mathrm{E}+00$ & & $3.1 \mathrm{E}+01$ & $7.7 E-01$ \\
\hline${ }^{238} \mathrm{Pu}^{b}$ & $4.7 E-03$ & $2.4 \mathrm{E}+01$ & & $5.2 E+00$ & $1.3 E-01$ \\
\hline${ }^{239} \mathrm{Pu}{ }^{b}$ & $1.9 E-03$ & $4.2 E-01$ & & $4.6 E+00$ & $1.2 E-01$ \\
\hline${ }^{240} \mathrm{Pu}{ }^{b}$ & $1.9 E-03$ & $4.3 E-01$ & & $4.6 \mathrm{E}+00$ & $1.2 \mathrm{E}-01$ \\
\hline${ }^{241} \mathrm{Am}^{b}$ & $2.1 E-03$ & $8.5 E-01$ & & $4.4 \mathrm{E}+00$ & $1.1 \mathrm{E}-01$ \\
\hline${ }^{241} \mathrm{Pu}$ & $6.1 E-02$ & $2.5 \mathrm{E}+01$ & $3.5 \mathrm{E}+03^{d}$ & $2.4 \mathrm{E}+02$ & $5.9 E+00$ \\
\hline${ }^{242 \mathrm{~m}} \mathrm{Am}^{b}$ & $1.9 E-03$ & $1.6 \mathrm{E}+00$ & & $4.6 \mathrm{E}+00$ & $1.2 \mathrm{E}-01$ \\
\hline${ }^{242} \mathrm{Cm}^{f}$ & & & $2.0 \mathrm{E}+04^{d}$ & $2.0 \mathrm{E}+02$ & $5.1 \mathrm{E}+00$ \\
\hline${ }^{242} \mathrm{Pu}^{b}$ & $2.0 E-03$ & $4.3 E-01$ & & $5.0 E+00$ & $1.2 E-01$ \\
\hline${ }^{243} \mathrm{Am}^{b}$ & $1.0 \mathrm{E}-03$ & $2.3 E-01$ & & $4.4 \mathrm{E}+00$ & $1.1 \mathrm{E}-01$ \\
\hline${ }^{243} \mathrm{Cm}^{b}$ & $1.8 E-02$ & $3.4 E+02$ & & $6.7 E+00$ & $1.7 E-01$ \\
\hline${ }^{244} \mathrm{Cm}$ & $1.4 E-01$ & $1.6 E+02$ & & $8.6 E+00$ & $2.1 E-01$ \\
\hline${ }^{244} \mathrm{Pu}^{b}$ & $6.1 E-04$ & $1.3 E-01$ & & $5.0 E+00$ & $1.2 \mathrm{E}-01$ \\
\hline${ }^{245} \mathrm{Cm}^{b}$ & $1.3 E-03$ & $2.2 \mathrm{E}-01$ & & $4.4 E+00$ & $1.1 E-01$ \\
\hline${ }^{246} \mathrm{Cm}^{b}$ & $1.8 E-03$ & $4.2 E-01$ & & $4.3 E+00$ & $1.1 \mathrm{E}-01$ \\
\hline${ }^{247} \mathrm{Cm}^{b}$ & $5.6 E-04$ & $1.2 E-01$ & & $4.8 E+00$ & $1.2 \mathrm{E}-01$ \\
\hline${ }^{248} \mathrm{Cm}^{b}$ & $5.1 E-04$ & $1.1 E-01$ & & $1.2 E+00$ & $3.0 \mathrm{E}-02$ \\
\hline
\end{tabular}

${ }^{a}$ Limit for isotope in activated metal.

${ }^{b}$ The Category 3 limit is the lower of this value and $100 \mathrm{nCi} / \mathrm{g}$.

' A blank in the Category 3 limit or the Class $\mathrm{C}$ limit indicates that no upper limit exists for this isotope.

${ }^{d}$ These limits are in nanocuries per gram of waste.

- $100 \mathrm{nCi} / \mathrm{g}$ is the Class $\mathrm{C}$ limit for alpha emitting transuranic nuclides with half lives greater than FIVE years).

${ }^{f}$ ISB limits for these isotopes are less than the Category 1 limit. If these isotopes are present in Category 1 waste, the waste must be checked against the combustible and noncombustible limits. 
Table B.3 Mobile radionuclide reporting $\left(\mathrm{Ci} / \mathrm{m}^{3}\right)$ for disposal at the Hanford Site (ref. 2)

\begin{tabular}{lc}
\hline Radionuclide & Reporting limit \\
\hline${ }^{3} \mathrm{H}$ & $4.4 \mathrm{E}+00$ \\
${ }^{14} \mathrm{C}$ & $1.3 \mathrm{E}-04$ \\
${ }^{36} \mathrm{Cl}$ & $9.2 \mathrm{E}-05$ \\
${ }^{79} \mathrm{Se}$ & $3.4 \mathrm{E}-05$ \\
${ }^{99} \mathrm{Tc}$ & $2.1 \mathrm{E}-04$ \\
${ }^{129} \mathrm{I}$ & $1.0 \mathrm{E}-06$ \\
${ }^{187} \mathrm{Re}$ & $3.3 \mathrm{E}-02$ \\
$\mathrm{U}(\mathrm{all})$ & $1.4 \mathrm{E}-05$ \\
${ }^{237} \mathrm{~Np}$ & $1.1 \mathrm{E}-05$ \\
\hline
\end{tabular}


Table B.4 Radionuclide action levels for waste characterization and reporting pertaining to waste acceptance at the NTS

\begin{tabular}{|c|c|c|c|}
\hline Nuclide & $\begin{array}{c}\text { Action level } \\
\left(\mathrm{Ci} / \mathrm{m}^{-3}\right)\end{array}$ & Nuclide & $\begin{array}{c}\text { Action level } \\
\left(\mathrm{Ci} / \mathrm{m}^{-3}\right)\end{array}$ \\
\hline $\begin{array}{l}\text { Any nuclide not listed } \\
\text { with } a t_{1 / 2}<5 \text { year }\end{array}$ & No limit & ${ }^{227} \mathrm{Ac}$ & 27.000 \\
\hline${ }^{3} \mathrm{H}$ & $1.5 \times 10^{5}$ & ${ }^{220} \mathrm{Th}$ & 0.110 \\
\hline${ }^{14} \mathrm{C}$ & $6.3 \times 10^{-3}$ & ${ }^{230} \mathrm{Th}$ & 0.034 \\
\hline${ }^{36} \mathrm{Cl}$ & 0.30 & ${ }^{232} \mathrm{Th}$ & 0.022 \\
\hline${ }^{59} \mathrm{Ni}$ & $2.2 \times 10^{2}$ & ${ }^{231} \mathrm{~Pa}$ & 0.038 \\
\hline${ }^{63} \mathrm{Ni}$ & $7.0 \times 10^{3}$ & ${ }^{232} \mathrm{U}$ & 0.250 \\
\hline${ }^{60} \mathrm{Co}$ & No limit & ${ }^{233} \mathrm{U}$ & 0.170 \\
\hline${ }^{90} \mathrm{Sr}$ & 40 & ${ }^{234} U$ & 0.026 \\
\hline${ }^{93} \mathrm{Zr}$ & $3.9 \times 10^{2}$ & ${ }^{235} U$ & 0.130 \\
\hline${ }^{99} \mathrm{Tc}$ & 3 & ${ }^{236} \mathrm{U}$ & 3.200 \\
\hline${ }^{107} \mathrm{Pd}$ & $3.6 \times 10^{3}$ & ${ }^{238} \mathrm{U}$ & 1.600 \\
\hline${ }^{126} \mathrm{Sn}$ & 0.016 & ${ }^{237} \mathrm{~Np}$ & 0.019 \\
\hline${ }^{126} \mathrm{I}$ & 0.08 & ${ }^{236} \mathrm{Pu}$ & 6.300 \\
\hline${ }^{133} \mathrm{Ba}$ & No limit & ${ }^{238} \mathrm{Pu}$ & 3.300 \\
\hline${ }^{135} \mathrm{Cs}$ & 77 & ${ }^{239} \mathrm{Pu}$ & 0.610 \\
\hline${ }^{137} \mathrm{Cs}$ & 9.2 & ${ }^{240} \mathrm{Pu}$ & 0.610 \\
\hline${ }^{151} \mathrm{Sm}$ & $3.3 \times 10^{4}$ & ${ }^{24 !} \mathrm{Pu}$ & 14.000 \\
\hline${ }^{152} \mathrm{Eu}$ & $1.3 \times 10^{3}$ & ${ }^{242} \mathrm{Pu}$ & 0.640 \\
\hline${ }^{154} \mathrm{Eu}$ & $3.2 \times 10^{5}$ & ${ }^{241} \mathrm{Am}$ & 0.480 \\
\hline${ }^{210} \mathrm{~Pb}$ & $3.5 \times 10^{2}$ & ${ }^{243} \mathrm{Am}$ & 0.190 \\
\hline${ }^{207} \mathrm{Bi}$ & 3.0 & ${ }^{242} \mathrm{Cm}$ & 650.000 \\
\hline${ }^{226} \mathrm{Ra}$ & 0.035 & ${ }^{244} \mathrm{Cm}$ & 210.000 \\
\hline${ }^{227} \mathrm{AC}$ & 27 & ${ }^{248} \mathrm{Cm}$ & 0.170 \\
\hline
\end{tabular}


Table B.5 Summary of WAC limiting parameters ${ }^{a}$ for CH-TRU waste at the WIPP-Waste container requirements/criteria

\begin{tabular}{ccc}
\hline $\begin{array}{c}\text { Criterion/require- } \\
\text { ment and section }\end{array}$ & Limiting parameter(s) & $\begin{array}{c}\text { Source(s) of } \\
\text { limit(s) }\end{array}$ \\
\hline $\begin{array}{c}\text { Waste containers } \\
3.2 .1\end{array}$ & $\begin{array}{c}\text { Containers shall be noncombustible and meet U.S. Department of } \\
\text { Transportation (DOT) Type A packaging requirements. }\end{array}$ & 1 \\
& $\begin{array}{c}\text { Current TRUPACT-II requirements limit acceptable containers to } \\
55 \text {-gal drums, standard waste boxes (SWBs), or SWB overpack of } \\
\text { 55-gal drums or test bins. }\end{array}$ & 2 \\
& $\begin{array}{l}\text { Current TRUPACT-II limits are 55-gal drums in two seven-packs or } \\
\text { two SWBs. }\end{array}$ & 2 \\
Waste package size & $\begin{array}{l}\text { All packages shall be configured as specified in the TRUPACT-II } \\
\text { Waste packaging } \\
\text { handling 3.2.2 }\end{array}$ & Safety Analysis Report for Packaging (SARP) (3.2.2 above). \\
\hline
\end{tabular}

a Source(s) of limit(s): (1) WIPP operations and safety criteria, (2) transportation-waste package requirements: TRAMPAC, (3) RCRA requirements, and (4) performance-assessment criteria. 
Table B.6 Summary of WAC limiting parameters ${ }^{a}$ for CH-TRU waste at the WIPP-Waste form requirements/criteria

\begin{tabular}{|c|c|c|}
\hline $\begin{array}{l}\text { Criterion/require- } \\
\text { ment and section }\end{array}$ & Limiting parameter(s) & $\begin{array}{l}\text { Source(s) of } \\
\text { limit(s) }\end{array}$ \\
\hline $\begin{array}{l}\text { Immobilization } \\
3.3 .1\end{array}$ & $\begin{array}{l}\text { Waste materials shall be immobilized if }>1 \mathrm{wt} \% \text { is particulate } \\
\text { material }<10 \mu m \text { in diameter or if }>15 \mathrm{wt} \% \text { is particulate material } \\
<200 \mu m \text { in diameter. }\end{array}$ & 1 \\
\hline Liquids 3.3 .2 & $\begin{array}{l}\text { Only residual liquids; as a guideline, residual liquid in well-drained } \\
\text { internal containers to be restricted to } \sim 1 \text { vol } \% \text { of the internal } \\
\text { container; aggregate amount of residual liquid }<1 \text { vol } \% \text { of } \\
\text { external container. }\end{array}$ & 1 \\
\hline $\begin{array}{l}\text { Pyrophoric materials } \\
3.3 .3\end{array}$ & $\begin{array}{l}\text { No nonradionuclide pyrophorics permitted. Radionuclides in } \\
\text { pyrophoric form are limited to }<1 \mathrm{wt} \% \text { in each waste package. }\end{array}$ & 2,3 \\
\hline $\begin{array}{l}\text { Explosives and } \\
\text { compressed gases }\end{array}$ & No explosives (49 CFR Part 173, Subpart C) are permitted. & $1,2,3$ \\
\hline 3.3 .4 & No compressed gases are permitted. & 2 \\
\hline \multirow[t]{7}{*}{$\begin{array}{l}\text { TRU mixed wastes } \\
\text { 3.3.5 }\end{array}$} & $\begin{array}{l}\text { TRU wastes shall contain no hazardous wastes unless they exist as co- } \\
\text { contaminants with transuranics. }\end{array}$ & 1 \\
\hline & $\begin{array}{l}\text { Waste generators must determine if their wastes are regulated by } \\
\text { RCRA and meet the requirements in the WIPP RCRA Part A and } \\
\text { Part B permit applications. }\end{array}$ & 3 \\
\hline & $\begin{array}{l}\text { Generators must document procedures for sampling, analytical } \\
\text { protocols, QA/quality control (QC) guidelines, and other } \\
\text { information called for in } 40 \text { CFR Parts } 264.13 \text { and } 265.13 \text { in a } \\
\text { site-specific Quality Assurance Project Plan (QAPjP). }\end{array}$ & 3 \\
\hline & $\begin{array}{l}\text { Characteristic ignitable (D001), corrosive (D002), and reactive } \\
\text { (D003) wastes are not acceptable at WIPP. }\end{array}$ & $1,2,3$ \\
\hline & $\begin{array}{l}\text { Any waste container sent to WIPP or loaded into a bin destined for } \\
\text { WIPP must meet the two times }(2 \mathrm{X}) \text { the maximum comparability } \\
\text { requirement for five nonflamable VOCs as specified in the NMD. }\end{array}$ & 3 \\
\hline & $\begin{array}{l}\text { Any waste container sent to WIPP must meet the ten times }(10 \mathrm{X}) \\
\text { the average comparability requirement for three nonflamable } \\
\text { VOCs as specified in the no-migration determination (NMD). }\end{array}$ & 3 \\
\hline & $\begin{array}{l}\text { Sludges shall be analyzed for total VOCs and toxic metals } \\
\text { specified in the NMD. }\end{array}$ & 3 \\
\hline $\begin{array}{l}\text { Specific activity of } \\
\text { waste } 3.3 .6\end{array}$ & $\begin{array}{l}\text { Waste shall be greater than } 100 \mathrm{nCi} \text { of TRU per gram of waste, } \\
\text { exclusive of added shielding, rigid liners, and the waste containers, } \\
\text { including alpha-contaminated wastes handled as TRU under DOE } \\
\text { Order } 5820.2 \mathrm{~A} \text {. }\end{array}$ & 1 \\
\hline
\end{tabular}

${ }^{a}$ Source(s) of limit(s): (1) WIPP operations and safety criteria, (2) transportation-waste package requirements: TRAMPAC, (3) RCRA requirements and (4) performance-assessment criteria. 
Table B.7 Summary of WAC limiting parameters ${ }^{a}$ for $\mathrm{CH}-\mathrm{TRU}$ waste at the WIPP-Waste package requirements/criteria

\begin{tabular}{|c|c|c|}
\hline $\begin{array}{l}\text { Criterion/require- } \\
\text { ment and section }\end{array}$ & Limiting parameter(s) & $\begin{array}{l}\text { Source(s) } \\
\text { of limit(s) }\end{array}$ \\
\hline \multirow[t]{3}{*}{$\begin{array}{l}\text { Waste package } \\
\text { weight 3.4.1 }\end{array}$} & $\begin{array}{l}\text { Current waste package limits are } 1000 \mathrm{lbs} \text { per } 55 \text {-gal drum, or } 4000 \\
\mathrm{lbs} / \mathrm{SWB} \text {. }\end{array}$ & 2 \\
\hline & TRUPACT-II payload is limited to $7265 \mathrm{lb}$. & 2 \\
\hline & $\begin{array}{l}\text { TRUPACT-II is limited to } 19,250-1 \mathrm{~b} \text { total gross weight, with a total } \\
\text { shipment gross vehicle weight (GVW) of } 80,000 \mathrm{lbs} \text {. }\end{array}$ & 2 \\
\hline \multirow{2}{*}{$\begin{array}{l}\text { Nuclear criticality } \\
{ }^{[39} \mathrm{Pu} \text { fissile } \\
\text { gram } \\
\text { equivalent } \\
\text { (FGE)] } 3.4 .2\end{array}$} & $\begin{array}{l}\text { Accepted package limits, including two times the error, are: } \\
-<200 \mathrm{~g} / 55 \text {-gal drum and } \\
-<325 \mathrm{~g} / \mathrm{SWB} \text {. }\end{array}$ & 2 \\
\hline & $\begin{array}{l}\text { The sum of FGE of all packages in TRUPACT-II payload shall be } \\
<325 \mathrm{~g} \text {. }\end{array}$ & 2 \\
\hline $\begin{array}{r}{ }^{239} \mathrm{Pu} \text { equivalent } \\
\text { activity } 3.4 .3\end{array}$ & Waste packages shall not exceed $1000 \mathrm{Ci}$ of ${ }^{239} \mathrm{Pu}$ equivalent activity. & 1 \\
\hline \multirow[t]{4}{*}{$\begin{array}{l}\text { Surface dose rate } \\
\quad 3.4 .4\end{array}$} & $\begin{array}{l}\text { Drums or SWBs shall not exceed } 200 \mathrm{mrem} / \mathrm{h} \text { surface reading, or } \\
10 \mathrm{mrem} / \mathrm{h} \text { at } 2 \mathrm{~m} \text {. }\end{array}$ & 1,2 \\
\hline & Shielded containers are allowed for ALARA purposes only. & 2 \\
\hline & Neutron contributors of $>20 \mathrm{mrem} / \mathrm{h}$ shall be separately documented. & 1 \\
\hline & $\begin{array}{l}\text { External dose rates on the loaded TRUPACT-II shall not exceed } \\
200 \mathrm{mrem} / \mathrm{h} \text { surface, or } 10 \mathrm{mrem} / \mathrm{h} \text { at } 2 \mathrm{~m} \text {. }\end{array}$ & 2 \\
\hline $\begin{array}{l}\text { Removable surface } \\
\text { contamination } \\
3.4 .5\end{array}$ & $\begin{array}{l}\text { Removable package surface contamination shall not be } \\
>50 \mathrm{pCi} / 100 \mathrm{~cm}^{2} \text { beta/gamma. }\end{array}$ & 1 \\
\hline \multirow[t]{3}{*}{$\begin{array}{l}\text { Thermal power } \\
\text { 3.4.6 }\end{array}$} & $\begin{array}{l}\text { Thermal (wattage) limits for individual waste packages, including } \\
\text { the error, are contained in the TRUPACT-II SARP. }\end{array}$ & 2 \\
\hline & TRUPACT-II load limits are contained in the TRUPACT-II SARP. & 2 \\
\hline & TRUPACT-II design limit is $40 \mathrm{~W}$. & 2 \\
\hline \multirow[t]{4}{*}{$\begin{array}{l}\text { Gas generation } \\
3.4 .7\end{array}$} & $\begin{array}{l}\text { All confinement layers, such as bags, shall be closed only by a twist- } \\
\text { and-tape or fold-and-tape method. }\end{array}$ & 2 \\
\hline & No sealed containers $>1$ gal may be in the waste. & 2 \\
\hline & The maximum number of confinement layers shall be known. & 2 \\
\hline & $\begin{array}{l}\text { Waste packages placed in WIPP during the experimental period shall } \\
\text { not exceed } 50 \% \text { of lower explosive limit in any confinement layer }\end{array}$ & 3 \\
\hline
\end{tabular}

B-10 
Table B.7 Summary of WAC limiting parameters ${ }^{a}$ for CH-TRU waste at the WIPP-Waste package requirements/criteria (continued)

\begin{tabular}{|c|c|c|}
\hline $\begin{array}{l}\text { Criterion/require- } \\
\text { ment and section }\end{array}$ & Limiting parameter(s) & $\begin{array}{l}\text { Source(s) } \\
\text { of limit(s) }\end{array}$ \\
\hline \multirow[t]{12}{*}{$\begin{array}{l}\text { Gas generation } \\
3.4 .7 \text { (continued) }\end{array}$} & $\begin{array}{l}\text { Total flammable VOCs are limited to } 500 \mathrm{ppm} \text { in the head-space gas } \\
\text { of waste packages. }\end{array}$ & 2 \\
\hline & $\begin{array}{l}\text { If total flammable VOCs are }>500 \mathrm{ppm} \text { in the head space, a flame } \\
\text { test must be performed prior to emplacement of the waste in the } \\
\text { WIPP. }\end{array}$ & 3 \\
\hline & $\begin{array}{l}\text { If total flammable VOCs are }>500 \mathrm{ppm} \text { in head space, a Le Chatelier } \\
\text { calculation is necessary. }\end{array}$ & 3 \\
\hline & $\begin{array}{l}\text { All chemicals/materials }>1 \mathrm{wt} . \% \text { must be evaluated for compatibility } \\
\text { within the waste form and with TRUPACT-II materials of } \\
\text { construction. }\end{array}$ & 2 \\
\hline & $\begin{array}{l}\text { Trace chemicals ( }<1 \mathrm{wt} \% \text {.limit) must total }<5 \mathrm{wt} \% \text { of the waste in } \\
\text { any package. }\end{array}$ & 2 \\
\hline & $\begin{array}{l}\text { Chemicals and other materials present in concentrations greater than } \\
1 \mathrm{wt} \% \text { shall conform to the allowable chemicals in each waste } \\
\text { material type. }\end{array}$ & 2 \\
\hline & Real-time radiography or equivalent examination. & 4 \\
\hline & $\begin{array}{l}\text { Visual characterization of solid waste for ten waste categories listed } \\
\text { in the QAPjP. }\end{array}$ & 4 \\
\hline & $\begin{array}{l}\text { Analysis of sludges for } \mathrm{pH} \text { and major cations and anions listed in the } \\
\text { Sandia National Laboratory (SNL) Bin-Scale Test Plan. }\end{array}$ & 4 \\
\hline & $\begin{array}{l}\text { Total alpha activity of waste on a container basis using methodology } \\
\text { listed in QAPjP. }\end{array}$ & 4 \\
\hline & $\begin{array}{l}\text { All waste packages shipped in TRUPACT-II shal be vented with one } \\
\text { or more filters that meet specifications listed in the TRUPACT-II } \\
\text { SARP. }\end{array}$ & 2 \\
\hline & All rigid liners shall be punctured or vented. & 2 \\
\hline \multirow[t]{3}{*}{ Labeling 3.4.8 } & $\begin{array}{l}\text { A unique identification barcode label expected to last } 10 \text { years shall } \\
\text { be affixed. }\end{array}$ & 1,2 \\
\hline & Each package shall have appropriate DOT labels. & $1,2,3$ \\
\hline & Each package shall be marked with the shipping category. & 2 \\
\hline
\end{tabular}

a Source(s) of limit(s): (1) WIPP operations and safety criteria, (2) transportation-waste package requirements: TRAMPAC, (3) RCRA requirements, and (4) performance-assessment criteria. 
Table B.8 Summary of WAC limiting parameters ${ }^{a}$ for CH-TRU waste at the WIPP-Data package and other requirements/criteria

\begin{tabular}{|c|c|c|}
\hline $\begin{array}{l}\text { Criterion/require- } \\
\text { ment and section }\end{array}$ & Limiting parameter(s) & $\begin{array}{l}\text { Source.(s) of } \\
\text { limit(s) }\end{array}$ \\
\hline \multirow[t]{4}{*}{$\begin{array}{l}\text { Data package/ } \\
\text { certification } 3.5 .1\end{array}$} & $\begin{array}{l}\text { A data package with certification shall be transmitted prior to } \\
\text { shipment. }\end{array}$ & 1 \\
\hline & $\begin{array}{l}\text { Documentation for certification of individual packages or a group of } \\
\text { packages for shipment in each TRUPACT-II unit shall be } \\
\text { submitted. }\end{array}$ & 2 \\
\hline & $\begin{array}{l}\text { A hazardous waste manifest shall be utilized for each shipment of } \\
\text { TRU mixed waste. }\end{array}$ & 3 \\
\hline & Information required by the WIPP shall be provided. & 4 \\
\hline \multirow[t]{4}{*}{$\begin{array}{l}\text { Additional } \\
\text { requirements 3.6.1 }\end{array}$} & $\begin{array}{l}\text { All packages in a single TRUPACT-II shall belong to the same } \\
\text { shipping category. }\end{array}$ & 2 \\
\hline & $\begin{array}{l}\text { Each package shipped shall belong to one of the content codes } \\
\text { defined in TRUCON. }\end{array}$ & 2 \\
\hline & $\begin{array}{l}\text { Retrievably stored waste that has been unvented shall be vented } \\
\text { and aspirated per the TRUPACT-II SARP. }\end{array}$ & 2 \\
\hline & $\begin{array}{l}\text { Payload control procedures outlined in Sect. } 7.4 .3 \text { of the } \\
\text { TRUPACT-II SARP shall be followed. }\end{array}$ & 2 \\
\hline
\end{tabular}

a Source(s) of limit(s): (1) WIPP operations and safety criteria, (2) transportation-waste package requirements: TRAMPAC, (3) RCRA requirements, and (4) performance-assessment criteria. 


\section{REFERENCES}

1. Energy Systems Waste Management Organization, Waste Acceptance Criteria for the Oak Ridge Reservation, ES/WM-10, Lockheed Martin Energy Systems, Oak Ridge, Tennessee, July 1994.

2. Hanford Site Solid Waste Acceptance Criteria, WHC-EP-0063-4, Westinghouse Hanford Company, Richland, Washington, November 1993 (revised May 1996). 
Appendix C

GUIDANCE FOR TRANSFER OF EXCESS RADIOACTIVE MATERIALS 


\section{GUIDANCE FOR TRANSFER OF EXCESS RADIOACTIVE MATERIALS}

\section{C.1. INTRODUCTION}

ORNL has significant quantities of radioactive materials which no longer have any planned use. In addition, ORNL has radioactively contaminated materials and equipment assigned to ORNL divisions other than WMRAD, for which (a) no planned or foreseen use exists, and (b) no current ORNL waste storage or disposal methodology can be effectively used. In general, these items have not been identified as waste. Many items are simply surplus and can be used in other programs with little or no modification, but with significant transfer costs. Other items will require significant decontamination, packaging, or disassembly costs before further use or transfer is possible. As funding is reduced for the research and operating divisions at ORNL, it can be expected that these divisions will make every effort to close unused facilities and retrofit others to make the best use of scarce resources. Frequently, however, a stock of radioactive or contaminated material will prevent an unused facility from either being closed, downgraded to a less costly safety status, or reused for other purposes. Therefore, there will be a strong pressure to transfer these materials.

DOE property management regulations are configured to manage radioactive and contaminated government property in the same manner as nonradioactive government property. That is, these materials are not supposed to be declared "waste" until a legitimate effort has been made to find another government user or a commercial sale of the property. For example, a gamma radiation source unit used at ORNL for research contains radioisotope material which might be used for industrial or medical purposes. Every effort should be made to reuse this material rather than incur the cost of disposal or storage of the material at an ORNL waste management site. In the past, there has been little pressure to handle these materials as surplus property (although it has been done twice in the last 5 years), nor have there been as great a variety of other uses for the materials as there are today. Consequently, no specific written procedure exists for ORNL research and operating divisions to guide them in the transfer of this type of surplus property. Such written guidance is necessary because:

- There are important overall safety, nuclear material accountability, and liability issues associated with the transfer of this property that could be overlooked during the transfer by inexperienced personnel.

- Inappropriate cost collection mechanisms can result in significant losses of operational funds to LMER or LMES.

- DOE regulations require specific property management actions and protocols to ensure that all potential users of the surplus property are treated fairly.

- ORNL organizations will need to interact with several different LMES organizations and oversight groups that have interest in such surplus property transactions.

To fill this need, ORNL Waste Management has provided this informal guidance for the disposition of excess radioactive and contaminated materials. With such guidance available, research and operating divisions at ORNL can take the actions necessary for disposition of such excess materials 
independent of WMRAD because these materials are not waste. As pointed out previously, the procedure for disposition of these materials is essentially the same process as that used for disposition of nonradioactive excess property. That function is centralized at LMES. Furthermore, discussions concerning this matter with other LMES organizatons indicate that disposition of such excess materials can be expected at all LMES sites as the site missions change. ORNL Waste Management has a definite interest in ensuring that the disposition of these excess materials is performed according to DOE regulations and that ORNL will support the effort needed to modify this procedure with input and review by experienced, knowledgeable technical staff.

\section{C.2. PROCEDURAL OVERVIEW}

Disposition of surplus government radioactive materials is simple in concept. First, an effort is made to give the materials to another organization which might wish to have them. Usually, other DOE and government organizations get first priority for such donations; universities get second priority. Second, an effort is made to recover as much of the cost either originally expended to procure,or fabricate these materials or needed to transfer these materials to another "owner." This cost recovery is achieved by offering the materials for sale by an authorized government property sales organization. Such materials may be sold to the highest bidder just like other nonradioactive property. Conditions of the sale are negotiable. Third, if no buyers are forthcoming, cooperative agreements with private or commercial interests are considered. Included in this type of transaction is the situation in which the government offers remuneration in some form to allow the transaction to occur. Finally, if no organization can be located which wishes to purchase or accept the materials, the materials may be declared to be waste, and an effort will be required to store or transfer the materials for final disposal. Figure C. 1 is a schematic diagram of this procedural overview.

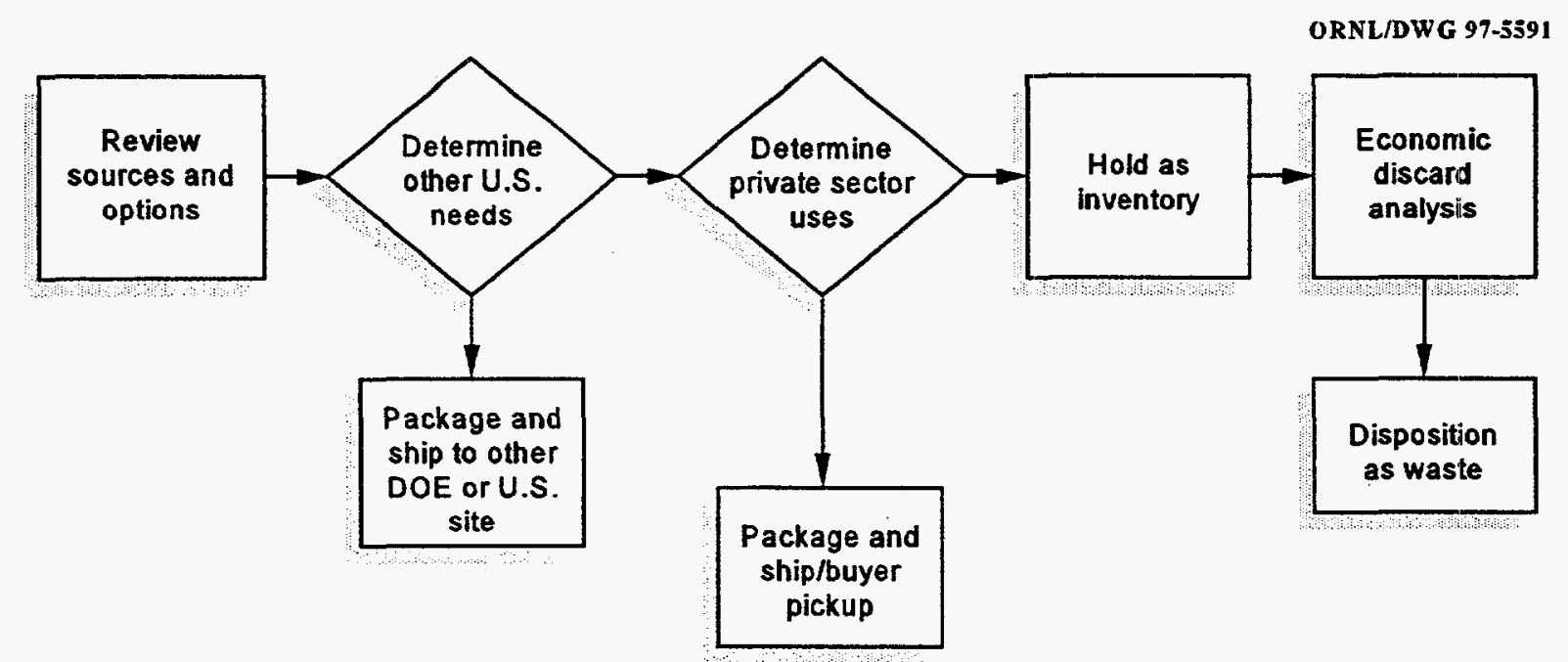

Fig. C.1. Procedural overview of the transfer of surplus radioactive material. 


\section{C.3. SALE OF SURPLUS RADIOACTIVE PROPERTY}

As noted previously, surplus materials must be offered for sale by an authorized government property sales organization. This restriction prevents individual employees from selling government property for personal profit. At ORNL two such organizations are available. The Chemical Technology Division Isotope Sales (IS) organization is specifically organized to sell to authorized buyers those radioactive isotopes that are not otherwise available commercially. The proceeds of the sale are deposited to the U.S. Treasury. Alternatively, the ORNL Property Management organization is authorized to sell surplus government property of all kinds through the LMES Property Sales organization. Any proceeds of the sale in excess of the costs incurred in the transfer of the surplus property are deposited to the U.S. Treasury. The IS organization operates on a charge-back basis; the Property Management organization is a laboratory overhead function. In both cases, the sales activity is a clear sale. That is, the ownership and liability of the surplus property are transferred to the buyer as soon as the sale is completed. At the end of the sale, the United States no longer has any financial or legal obligation associated with the material.

\section{C.3.1 USING THE IS ORGANIZATION}

The IS organization deals in high-specific-activity, encapsulated materials which have a known market value. In general, the U.S. government may not sell for profit any materials or services which are sold commercially by U.S. firms. The IS organization was established to supply those radioactive materials which are not available commercially. However, the government may chose to surplus any excess material for which it has no further use. Freshly prepared ${ }^{60} \mathrm{Co}$ is an example of such a material. An ORNL division with such surplus materials for transfer can simply contact $R$. $\mathbf{L}$. Cline (574-6995), and he will take the transaction from this point, making arrangements as necessary. A specific charge account for costing of the time and materials necessary for shipment of the surplus materials must be established. In essence, the IS organization acts as a no-fee broker, providing the necessary services at cost.

\section{C.3.2 USING THE PROPERTY MANAGEMENT ORGANIZATION}

A division with (a) surplus material having little market value or (b) limited resources but desiring to demonstrate that all opportunities for transfer of the material have been exhausted may choose to explore the possibility of a sale of material through the ORNL Property Management organization. There are three major differences between using this organization and the IS organization. First, the overall supervision of the transaction will rest with the division holding the surplus material, and much of the planning and preparation will be performed by personnel of that division. Second, the Property Management organization personnel are trained specialists in property disposal operations, but have little experience or training in the movement of radioactive material. The responsibility for the actual transfer of the material and for compliance with the safety and regulatory requirements of such a transfer rests with the division holding the surplus material. In essence, the Property Management organization provides the point of sale and the legal mechanism for the clear sale of the material as part of that organization's general support function to the Laboratory. All other responsibility rests with the division holding the material. Third, although no transfer of radioactive material is rapid, 
the planning and coordination phase of the sale through the Property Management organization will take longer because of the procedural requirements. Figure C.2 is a schematic diagram of these requirements.

- The division holding the material must gather all known data and provide a succinct description of the surplus material (Fig. C.2, Block 1). The description must include what is known and what is not known regarding the radioactivity of the material, its physical characteristics, its chemical makeup, and its shipping requirements. In preparing the description, it may be assumed that the potential buyer has a working knowledge of radioactive materials, since the material can only be sold to a holder of an NRC license or equivalent. (Caution: This description will be used throughout the transaction process and must be as accurate as possible; if the description is not correct, the government is liable for any costs introduced by a discrepancy.) For instance, one can imagine the problems introduced if a buyer purchases a surplus beta-radiation source, ships it to an alpha-radiation-free hot cell at that buyer's location, opens the final confinement, and finds an alpha source. Consequently, each word of the description should be checked for technical accuracy with cognizant personnel. Throughout the sales process, the use of the description by the Property Management organization in electronic mail, sales announcements, etc. should be checked by the division holding the material to ensure that error is not introduced into its retransmission.

- The division holding the material should prepare a disposition plan (Fig. C.2, Block 2) after reviewing this generic procedure. Since most surplus material transfers will involve different types of material, the required coordination and mechanics of the transfer will be specific to the material being transferred. To avoid having the laboratory waste valuable personnel resource time, the plan details should be checked with the key organizational elements routinely involved in radioactive material transfers to ensure their accuracy.

The WMRAD (D. W. Tumer, 576-2017) will provide advice, as will Chemical Technology Division (B. D. Patton, 576-0603) and LMES Transportation Safety (TS) and Compliance (M. B. Hawk, 574-6042). There are two important by-products of this planning and coordination. First, these organizational elements will be able to recommend ways to avoid unnecessary costs and liabilities. Second, rather than having each division attempt individual transfers of radioactive material, ways may be found to consolidate or otherwise streamline the transfer effort.

\section{C.3.2.1 Initiating the Sale Through the Property Management Organization}

At ORNL the sale transaction (Fig. C.2, Block 3) is initiated with a call to A. L. Martin (576-7610). Martin operates the ORNL surplus property disposal point at Bldg. 7605 (in the Robotics and Process Systems Complex). Prior to this call, the division holding the surplus material will need to do some preparatory work to provide Martin information for the sale. This preparatory work is listed below: 


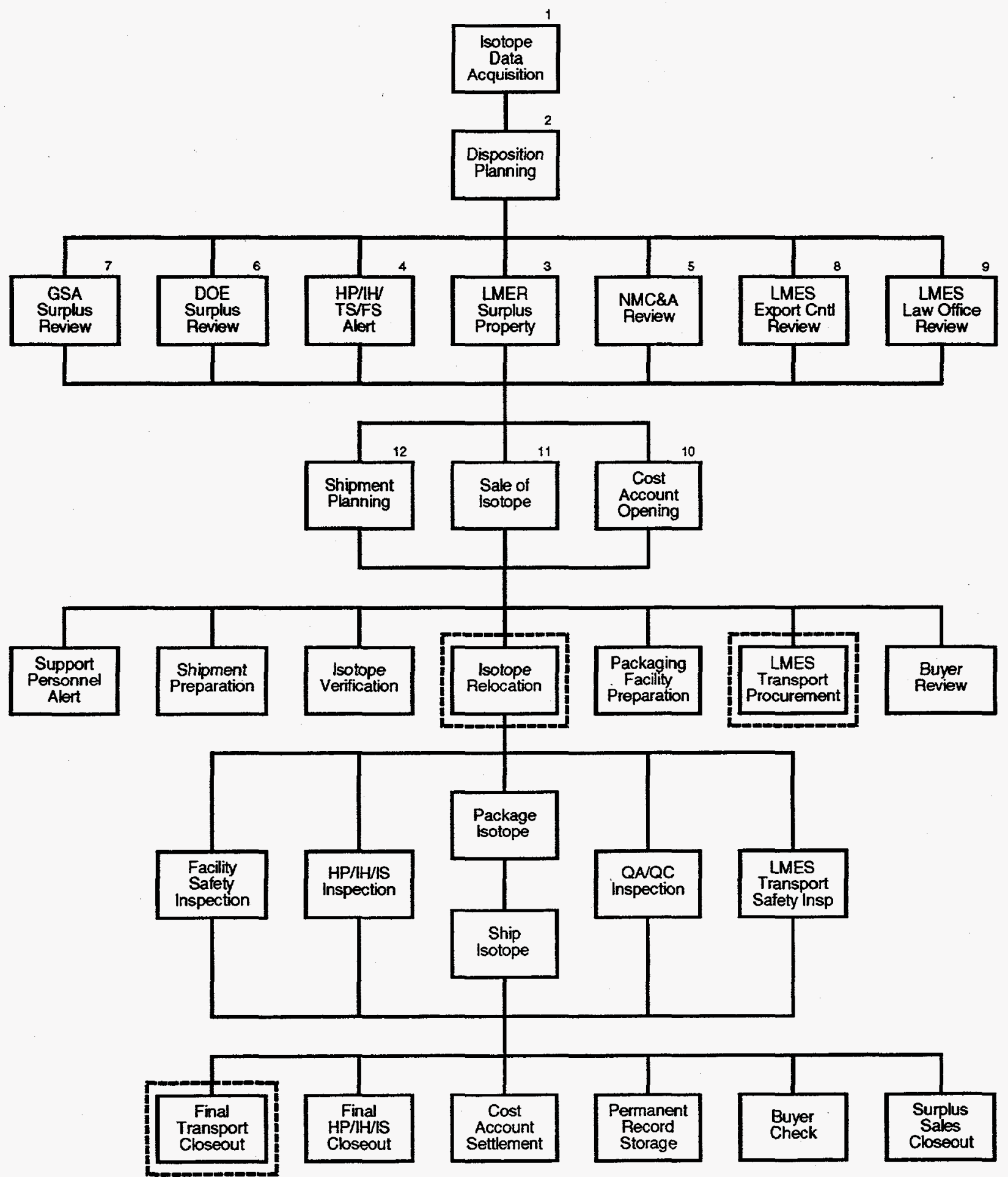

Fig. C.2. Surplus radioactive material transfer requirements. 
A representative of the division holding the material should be identified as the communication point of contact for the division. This identification will be critical for all further activities associated with this procedure.

- Before Martin can offer surplus material for sale without a Health Physics (HP) clearance label ("green tag"), permission is required from the appropriate ORNL Radiation Protection [also referred to as Health Physics (HP)] oversight personnel (Fig. C.2, Block 4). A copy of the description of the surplus material and an announcement of the intent to dispose of the material as surplus property should be sent to J. B. Hunt (576-5117). After a discussion with the division holding the material, Hunt will notify Martin that she can offer the material for sale.

- For those items which are accountable sealed sources, permission for the transfer is required from the ORNL Source Control organization (Fig. C.2, Block 4). A copy of the description of the surplus material and an announcement of the intent to dispose of the material as surplus property should be sent to K. R. Geber (574-0929). After discussion with the division holding the material, Geber will notify the division that the material can be offered for sale.

- For those items which contain hazardous materials, permission for the transfer is required from the ORNL Industrial Hygiene (IH) organization (Fig. C.2, Block 4). A copy of the description of the surplus material and an announcement of the intent to dispose of the material as surplus property should be sent to the $\mathrm{IH}$ representative having oversight of the items. After discussion with the division holding the material, the representative will notify the division that the material can be offered for sale.

- Later, both the ORNL Office of Operational Readiness and Facility Safety (OORFS) and the LMES TS and Compliance organizations will be involved in overseeing the transfer process. It is advisable to send a copy of the description of the surplus material and an announcement of the intent to dispose of the material as surplus property (Fig. C.2, Block 4) to J. F. Alexander (574-4340) and M. B. Hawk (574-6042) and discuss the proposed transfer with them at the earliest time.

- For those items which contain strategic "nuclear materials," as defined by DOE Order 5633.3A, (e.g., fissile isotopes, fissionable isotopes, neutron sources), permission for the transfer is required from the ORNL Nuclear Materials Control and Accountability (NMC\&A) organization (Fig. C.2, Block 5). In some cases and quantities, these materials are restricted from transfer. Additionally, both the ORNL and the Oak Ridge DOE NMC\&A organizations maintain an informal watch over any transactions of other radioactive materials to organizations outside the DOE. A copy of the description of the surplus material and an announcement of the intent to dispose of the material as surplus property should be sent to B. T. Fowler ORNL (574-7017). After discussion with the division holding the material, Fowler will notify the division which material can be offered for sale. This requirement points out the need for a complete description of the surplus material from the division holding the material. For example, a sealed source of ${ }^{137} \mathrm{Cs}$ is not restricted by this DOE order. However, a DU shield in which it is stored would be restricted from some types of transfer. 
- Property offered for sale by ORNL requires an Excess Property Tag (UCN 20426). Whether the tag will ever be fastened on the surplus material or not, Martin requires a completed tag and can supply an instruction sheet for completion of the tag. The "property condition" box labeled "obsolete/salvage" should be checked. Insert "N/A" in all the "custodian/technician" signature blocks. The "high-risk property" section box labeled "yes" should be checked.

- Property offered for sale by ORNL requires a review of its status as "high-risk property," where property requiring special handling, control, and disposition because its unintentional or premature release could pose risks to the public, the environment, or the interests of the United States. There are nine categories of high-risk property. Surplus radioactive materials will (at the least) meet the criteria for category 109-1.5302(g), "Radioactively Contaminated Property." This is "any item or material that is, in itself, radioactive or that is contaminated with radioactive material and which spontaneously emits ionizing radiation in excess of background radiation as measured on instrumentation suitable for the type of radiation being emitted." Depending on the type of surplus material or equipment, the criteria for one or more of the other eight categories may also be met. These are:

- Proliferation Sensitive Property

- Export Controlled Property

- Hazardous Property

- Special Nuclear Material
- Nuclear-related or Dual-use Property

- Military Critical Technologies List Property

- Specially Designed and Produced Property

- Unclassified Controlled Nuclear Information

In addition, property offered for sale requires a review to determine if it is on the "Trigger List." In general, an item on the Trigger List is useful for the production of nuclear weapons or their precursors.

Martin requires a completed High-Risk Property Checklist Form. Martin can supply the forms and an instruction sheet for completion of the form. Copies of the property management regulations defining high-risk property and Trigger List property are available. Enter the appropriate information in the "badge number" and "description of property" boxes. Circle the "excessing property" status in the "purpose for submitting..." box. Circle the "yes" status in the "results" box and briefly explain the reason for considering the property to be high risk.

High-risk property is not precluded from sale as surplus. It does, however, require a higher level review to determine under what conditions it may be transferred. Martin will arrange this review; the division holding the property may be called upon for additional information. For example, simple sealed source isotopes such as ${ }^{60} \mathrm{Co}$ and ${ }^{137} \mathrm{Cs}$ are considered "export controlled" and may not be transferred to North Korea, Libya, or Cuba at this time.

With the permission from ORNL Radiation Protection, the completed Excess Property Tag, and the completed High-Risk Property Checklist, Martin will initiate the sale procedure. This involves formally checking to determine if other DOE organizations will take the surplus material (Fig. C.2, Block 6), formally checking to determine if other U.S. Government organizations will take the surplus 
material (Fig. C.2, Block 7), obtaining an export control review for high-risk materials transfer (Fig. C.2, Block 8), and notification of key safety and compliance organizations of the transfer by electronic mail. These activities take about $30-45 \mathrm{~d}$.

While these checks are being completed, the division holding the material should be checking the sales contract. As noted previously, each sale of surplus material is likely to be different. Usually, a sale of surplus property is conducted "as-is, where-is" and allows a buyer to view and examine the surplus material. Usually a buyer is responsible for loading and transporting the purchased surplus property, and usually a buyer must take possession and transport the property within a set time. Clearly this may not be possible for high-specific-activity radioactive materials. Details will need to be placed in the sale contract, such as (1) where and when the buyer takes possession of the surplus material, (2) how the buyer can be assured that the material is as described in the sale announcement, (3) how the buyer can transport the surplus material, and (4) whether the buyer is responsible for loading and shipping the surplus material. Standard contract time restrictions on pickup of sold property may need to be altered. Buyers must be contractually obligated to ship radioactive materials in compliance with ORNL, DOE, and DOT requirements. The LMES Property Sales organization (J. D. Huddleston, 576-1451) has examples of surplus radioactive property sales contracts that can be used, but care must be taken at this point. Again, the Property Management organization personnel are trained specialists in property disposal operations, but have little experience or training in the movement of radioactive material. The responsibility for the actual transfer of the material and compliance with the safety and regulatory requirements of such a transfer rest with the division holding the surplus material. Sales contract requirements should be reviewed (Fig. C.2, Block 9) with the LMES Law Office (D. Ray, 576-6568).

\section{C.3.2.2 Conducting the Sale Through the Property Sales Organization}

Once Martin's checks are complete, she will formally request a sale of the property by the LMES Property Sales organization (J. D. Huddleston, 576-1451). To make this request, a financial account number into which the proceeds of the sale can be paid will be required. This should be a financial account belonging to the division holding the material, and organized by that division's finance officer as a cost recovery account (Fig. C.2, Block 10). That is, the account should allow charges from both the craft activities and the service charges required for loading and shipping the material to be accrued against the sales price. This allows the division holding the material to recover as much of its costs for disposition of the material as possible. The account will not be used until a sale is actually contracted and loading and shipping of the surplus material begins. Martin's activities are essentially completed at this point.

Huddleston will review the sale announcement and sale contract terms with the division holding the material for completeness and accuracy. In addition to the review, he will check to see if the division has knowledge of any potential bidders for the surplus materials. When the review is completed, the material will be formally offered for sale in several public documents as a minimum (Fig. C.2, Block 11). Additionally, potential bidders may be offered a chance to bid by invitation. This process will take at least $30 \mathrm{~d}$. 
Unless there is a reason to do otherwise, the materials will be offered for sale and sold to the firm presenting the highest sealed bid. The bid process is formalized and conducted by Property Sales. Personnel from the division holding the material may be contacted by Property Sales to answer technical or administrative questions from the bidders, but direct communication between the division holding the material and any potential bidders will generally invalidate the sale, opening the division to charges of collusion or giving unfair advantage to one specific bidder over another.

It turns out that only a few firms in the United States are licensed by the NRC to process and fabricate radioactive materials. Most of the other U.S. firms which are licensed to possess quantities of radioactive materials are radioactive material brokers or radioactive waste disposal operations. Surplus materials may be sold to any of these firms. Surplus materials may also be sold to firms outside the United States, if they have the IAEA equivalent of an NRC license and are not prohibited by export controls discussed previously. Technically, once the material is sold, the United States has no further responsibility or claim on it. Some due diligence is called for, however. A sale to an overseas radioactive material broker without an adequate inspection of the broker's background will probably not be favorably viewed. The LMES law office should be checked in the event a sale to such a buyer is contemplated.

While the bid process is being conducted, a detailed plan for loading and shipping the surplus material should be prepared (Fig. C.2, Block 12). Loading is the process of packaging the material for shipment off-site according to DOE and DOT regulations. Shipping is the process of obtaining all the necessary documentary permission to transport the material off-site in the buyer's transport container on the buyer's transport vehicle and placing the packaged material on the transport vehicle and conducting the final inspection. Unless otherwise negotiated in the sales contract, the sale is complete, and funds are paid to the division's cost recovery account once the loading and shipping are completed and the vehicle is ready for dispatch. However, transferring radioactive material of any type is a carefully controlled process from start to finish and involves several organizations at ORNL. Divisions with little experience in this area will need to contact the TS and Compliance organization for a complete briefing on the procedures required.

There are three possible outcomes of the bid process: (1) A buyer may present a high bid and claim the sale, (2) no bidders may elect to participate, or (3) bidders may present counteroffers. For the situation in which a buyer claims the sale as the high bidder, the Property Sales organization will conduct the formal sales paperwork, verifying that all of the terms and conditions of the sale contract are understood and completed by both the buyer and the United States. It may be that the sale is held up temporarily because a losing buyer appeals the award of the sale. Again, the Property Sales organization will conduct the procedural aspects of the sale, including any appeal responses. For the situation in which no bidders elect to participate, the Property Sales organization will send a notice to the division holding the material that no buyers could be located for the material. For the situation in which a counteroffer is made by a bidder, the Property Sales organization will send a notice to the division holding the material and negotiate a response to the counteroffer. 


\section{C.3.2.3 Completing the Sale Through the Property Sales Organization}

Other than checking to ensure that the sales contract provisions are being met, the Property Sales organization will remain in the background as the division holding the surplus material loads and ships the material. Nevertheless, during the loading and shipping phase, all communication between the buyer and the division holding the material should either be routed through the Property Sales organization or take place as part of a Property Sales-initiated conference call. This prevents inadvertent commitment of government resources because of mistakes in communications and also allows officially negotiated changes to the sales contract in the event that unexpected physical or administrative difficulties arise. This is particularly important when RH radioactive materials are being transferred, because mistakes in communication can result in significant reworking because of failure to meet loading and shipping quality standards or demurrage charges for leased shipping casks that are delayed in transit.

Finally, when the surplus material has been loaded and the shipping inspection completed, a Property Sales representative will oversee the payment of funds into the cost-recovery account and the release of the material to the buyer. 
Appendix D

ROUGH ESTIMATE FOR VOLUME OF SPECIAL CASE WASTE AT OAK RIDGE NATIONAL LABORATORY 


\section{ROUGH ESTIMATE FOR VOLUME OF SPECIAL CASE WASTE AT OAK RIDGE NATIONAL LABORATORY}

\section{D.1, INTRODUCTION}

For planning purposes, an estimate was requested for the potential volume of SCW present and expected at ORNL by 2006. Using the Special Case Waste Located at Oak Ridge National Laboratory Facilities-Survey Report by Forgy ${ }^{1}$ as a basis, specifically summary Tables A-3 through A- 6 in the appendix of that report, we prepared this estimate. Because most of this waste is unpackaged and uncharacterized and because the actual volume will depend on how the waste is reduced in volume and packaged for off-site shipment, this estimate must be considered as a roughorder-of-magnitude estimate. Since the Forgy report was written, SNF is no longer considered to be SCW. Therefore, this estimate does not include the table entries for SNF and fuel debris from the survey report.

\section{D.2 SUMMARY}

The estimate for the total SCW at ORNL is $800 \mathrm{~m}^{3}$. If the approach to D\&D of the defueled reactors is modified to emphasize entombment (backfilling the core cavities with grout), then a significant component of this material will not be processed and shipped to another location. Perhaps $250 \mathrm{~m}^{3}$ of other waste (SNF and some of the TRU wastes) could become special case if the current planned approaches do not materialize. Thus, overall the $800 \mathrm{~m}^{3}$ could become $500 \mathrm{~m}^{3}$ if less waste is generated because of a modified approach to the $\mathrm{D} \& \mathrm{D}$ of reactors. The estimate could become $1000 \mathrm{~m}^{3}$ if other waste becomes SCW when there is no off-site storage. The total rough order-ofmagnitude estimate is that the volume that should be planned for is in the range of 500 to $1000 \mathrm{~m}^{3}$ with a nominal value of $750 \mathrm{~m}^{3}$. A summary of the estimate is given in Table D.1. Details concerning the values in this table are given in the discussion which follows the table.

\section{D.2.1. Survey Report Table A-3}

Building 7900, High Flux Isotope Reactor (HFIR) Performance assessment limited material. The HFIR is an operating reactor and is expected to operate well into the next century. The SNF from HFIR is managed on site by the extensive in-pool storage afforded by the recent re-racking project at HFIR. Eventually, the SNF is to be shipped to the regional storage facility for aluminum-clad fuels or, if that becomes not possible for some reason, a backup alternative of on-site dry storage could be exercised. The pool is also used for SCW from the reactor, principally from reactor components and irradiation-test structural components.

The recent planning basis is that the fuel pool would need to be cleared of scrap about every 5 years. The pool was cleared of much of its scrap (not all was SCW) in preparation for the installation of new SNF racks. Reracking is completed, and scrap is accumulating. This means that by FY 2006, two more storage vaults of reactor internals will be stored at Building $7842 \mathrm{~A}$. The waste will not be fully characterized until it is prepared for waste acceptance. The agreement between DOE-NE and DOEEM is that DOE-NE must recover the waste materials from away-from-reactor-storage and prepare them for waste acceptance. This can be done most economically in the HFIR pool. 
Table D.1 Summary of estimated volumes of SCW by category

\begin{tabular}{|c|c|c|c|}
\hline Location & SCW category & $\begin{array}{l}\text { Volume } \\
\left(\mathrm{m}^{3}\right), \\
\text { legacy and } \\
\text { process }\end{array}$ & $\begin{array}{l}\text { Volume } \\
\left(\mathrm{m}^{3}\right) \\
\text { D\&D }\end{array}$ \\
\hline $\begin{array}{l}\text { Building } 7900, \text { High Flux Isotope } \\
\text { Reactor }\end{array}$ & $\begin{array}{l}\text { Performance assessment } \\
\text { limited (D\&D wastes up to } \\
150 \mathrm{~m}^{3} \text { not included in total) }\end{array}$ & 8 & \\
\hline $\begin{array}{l}\text { Building } 3025 E \text {, Irradiated Materials } \\
\text { Examination and Testing Facility }\end{array}$ & Uncharacterized waste & 10 & \\
\hline $\begin{array}{l}\text { Building } 3525 \text {, Irradiated Fuels } \\
\text { Examination Laboratory }\end{array}$ & Uncharacterized waste & 1 & \\
\hline ORNL buildings & Radiation Sources & 80 & \\
\hline $\begin{array}{l}\text { Building } 7503 \text {, Molten Salt Reactor } \\
\text { Experiment }\end{array}$ & Uncharacterized & & 100 \\
\hline $\begin{array}{l}\text { Building } 7500 \text {, Homogeneous Reactor } \\
\text { Experiment }\end{array}$ & Uncharacterized & & 100 \\
\hline Building 3010 , Bulk Shielding Facility & Uncharacterized & & 100 \\
\hline Building 7700 , Tower Shielding Facility & Uncharacterized & & 50 \\
\hline $\begin{array}{l}\text { Building } 3038 \text {, an isotope processing } \\
\text { facility }\end{array}$ & Uncharacterized & 1 & \\
\hline $\begin{array}{l}\text { Building } 3039 \text {, an isotope processing } \\
\text { facility }\end{array}$ & Uncharacterized & 1 & \\
\hline $\begin{array}{l}\text { Building } 3517 \text {, Fission Product } \\
\text { Development Laboratory }\end{array}$ & Uncharacterized & 50 & \\
\hline ORNL buildings & Excess nuclear materials & 10 & \\
\hline Building 7842A (HFIR Vault) & HFIR scrap & 4 & \\
\hline WMRAD SCW-accepted & & 10 & \\
\hline WMRAD SCW-might be Accepted & $\begin{array}{l}\text { NFS }-150 \mathrm{~m}^{3} \\
\text { Isotope-100 } \mathrm{m}^{3}\end{array}$ & 250 & \\
\hline Total-each & & 425 & 350 \\
\hline Grand Total-all SCW & & & 775 \\
\hline
\end{tabular}


Since HFIR is expected to be operating after the year 2006, and because it is unlikely that DOE and ORNL management would risk preparing the materials in the pool while the reactor is operating, the accumulated SCW in the storage vaults and in the pool cannot be processed, characterized, and packaged in the HFIR pool until after final HFIR shutdown. Since this material will probably not be prepared for shipment until after HFIR shutdown occurs, it will continue to accumulate and be stored well into the 21 st century. More expensive options for preparation of the waste for shipment are available, but these are unlikely to be exercised over the next two decades.

The volume of each storage vault for the HFIR SCW is about $8 \mathrm{~m}^{3}$. Some volume reduction can be expected when the waste is prepared for acceptance; however, the waste volume will really be based on whatever inner package of a Type B cask is used. A good estimate would be $4 \mathrm{~m}^{3}$ of scrap per cask. This does not include the final reactor D\&D scrap after the reactor is shut down and defueled.

Building 3025E, Irradiated Materials Examination and Testing Facility (Uncharacterized waste). If the building is cleared one waste can at a time, the facility will generate 50 Type B packages with just the existing scrap; a good estimate would be $10 \mathrm{~m}^{3}$. The facility is now out of storage space. Note that since the Forgy study was completed, M\&C Division has obtained work from non-DOE sources. This will generate more waste between now and 2006. The M\&C Division is negotiating space relief with WMRAD. If the SCW is accepted by WMRAD, then another 50 cans could be generated by the year 2006 .

Building 3525, Irradiated Fuels Examination Laboratory (Uncharacterized). If the building can be cleared one waste can at a time, one Type B package will be generated with existing waste. A good estimate would be $1 \mathrm{~m}^{3}$. Note that since the Forgy study was completed, $M \& C$ Division has been doing packaging work for the WMRAD. This will generate more waste between now and 2006, but the SCW generated by these operations can probably be packed with the waste being processed for WMRAD.

ORNL Buildings (Radiation sources). It may be highly cost prohibitive to clear these from the site one item at a time. Consolidation at a central location is necessary. Some items, however, are so active that they will require a single package. If best practices are followed, a good estimate will be $80 \mathrm{~m}^{3}$.

Building 7503, Molten Salt Reactor Experiment, MSRE (Uncharacterized). The volume of this waste cannot be accurately determined until it is determined how to demolish the reactor cells. Since this was a liquid fuel reactor, much of the scrap is activated piping and tanks. An order-of-magnitude estimate would be $100 \mathrm{~m}^{3}$.

Building 7500, Homogeneous Reactor Experiment (HRE) (Uncharacterized). This volume cannot be accurately determined until it is determined how to demolish the reactor cells. Since this was a liquid fuel reactor, much of the scrap is activated piping and tanks. An order of magnitude estimate would be $100 \mathrm{~m}^{3}$.

Building 3010, Bulk Shielding Reactor (BSR) (Uncharacterized). This volume cannot be accurately determined until it is determined how to demolish the reactor internals. Since this was a swimming 
pool reactor, much of the scrap is activated support framework with some piping and a few tanks. An order of magnitude estimate would be $100 \mathrm{~m}^{3}$.

Building 7700, Tower Shielding Facility, (TSF) (Uncharacterized). This volume cannot be accurately called until it is determined how to demolish the reactor internals. An order of magnitude estimate would be $50 \mathrm{~m}^{3}$.

Building 3038, an isotope processing facility (Uncharacterized). This waste would be pieces and parts of glove box and cell gear grossly contaminated with short half-life materials and with a few pure isotope sources of no value. A good estimate would be $1 \mathrm{~m}^{3}$.

Building 3029, an isotope processing facility (Uncharacterized). This waste would be pieces and parts of glove box and cell gear grossly contaminated with short half-life materials and a few pure isotope sources of no value. A good estimate would be $1 \mathrm{~m}^{3}$.

Building 3517, Fission Product Development Laboratory, FPDL (Uncharacterized). This waste would be pieces and parts of cell gear grossly contaminated with short half-life materials as well as a few pure isotope sources of no value. Several cells still retain the original chemical processing systems. A good estimate would be $50 \mathrm{~m}^{3}$.

ORNL Buildings (Excess muclear materials). It may be cost prohibitive to clear these from the site one item at a time. These can be expected to fall out of the SCW category as DOE determines a site for consolidation. If best practices are followed for characterization and packaging, a good estimate is $10 \mathrm{~m}^{3}$.

\section{D.2.2. Survey Report Table A-4}

This is the first HFIR cask of scrap stored at Building 7842A. Currently it cannot be prepared until HFIR is shut down or other arrangements for preparation and packaging are made. Four (4) $\mathrm{m}^{3}$ is estimated.

\section{D.2.2. Survey Report Table A-5}

These include waste items which have been accepted by WMRAD as SCW. Between now and 2006, if nothing else is accepted, there is less than $10 \mathrm{~m}^{3}$.

\section{D.2.3. Survey Report Table A-6}

These are waste items which might be accepted by WMRAD as SCW in the future. The NFS material is about $150 \mathrm{~m}^{3}$. The isotope stockpile will probably generate $100 \mathrm{~m}^{3}$ as currently planned. 


\section{REFERENCES}

1. J. R. Forgy, Jr., Special Case Waste Located at Oak Ridge National Laboratory Facilities-Survey Report, Waste Management and Remedial Action Division (WMRAD), 456-831-3, Lockheed Martin Energy Systems, Inc., Oak Ridge, Tennessee, September 1995. 